UNIVERSIDADE DE SÃO PAULO

ESCOLA DE COMUNICAÇÕES E ARTES

\title{
KATIA KREUTZ
}

\begin{abstract}
A jornada das heroínas:
protagonismo feminino no cinema contemporâneo brasileiro
\end{abstract}

São Paulo

2020 


\title{
KATIA KREUTZ
}

\begin{abstract}
A jornada das heroínas:
protagonismo feminino no cinema contemporâneo brasileiro
\end{abstract}

Versão Corrigida (versão original disponível na Biblioteca da ECA/USP)

Dissertação apresentada à Escola de Comunicações e Artes da Universidade de São Paulo para obtenção do título de Mestranda em Meios e Processos Audiovisuais

Área de concentração: Cultura Audiovisual e Comunicação

Orientadora: Prof ${ }^{\mathrm{a}}$. Dr ${ }^{\mathrm{a}}$. Irene de Araújo Machado

São Paulo

2020 
Autorizo a reprodução e divulgação total ou parcial deste trabalho, por qualquer meio convencional ou eletrônico, para fins de estudo e pesquisa, desde que citada a fonte.

Catalogação na Publicação Serviço de Biblioteca e Documentação

Escola de Comunicações e Artes da Universidade de São Paulo Dados inseridos pelo(a) autor(a)

Kreutz, Katia

A jornada das heroínas: protagonismo feminino no cinema contemporâneo brasileiro / Katia Kreutz ; orientadora, Irene Araújo Machado. -- São Paulo, 2020.

$119 \mathrm{p}$.

Dissertação (Mestrado) - Programa de Pós-Graduação em Meios

e Processos Audiovisuais - Escola de Comunicações e Artes /

Universidade de São Paulo.

Bibliografia

Versão corrigida

1. cinema 2. feminismo 3. protagonismo feminino 4. cinema

brasileiro contemporâneo I. Araújo Machado, Irene II. Título.

CDD 21.ed. - 791.43 
Nome: KREUTZ, Katia

Título: A jornada das heroínas: protagonismo feminino no cinema contemporâneo brasileiro Dissertação apresentada à Escola de Comunicações e Artes da Universidade de São Paulo para obtenção do título de Mestranda em Meios e Processos Audiovisuais

Aprovado em:

Banca Examinadora

Prof. Dr.:

Instituição:

Julgamento:

Assinatura:

Prof. Dr.:

Instituição:

Julgamento:

Assinatura:

Prof. Dr.:

Instituição:

Julgamento:

Assinatura: 


\section{AGRADECIMENTOS}

Ao meu parceiro de vida, Daniel Barreal, pela paciência e apoio em todos os momentos.

À minha irmã, Karen Kreutz, por estar presente - mesmo à distância - e acompanhar cada passo do desenvolvimento deste trabalho.

Aos meus pais, Ciro e Lúcia Kreutz, por sempre apoiarem minhas escolhas de vida e de carreira.

À minha orientadora, Prof ${ }^{\mathrm{a}}$. Dr ${ }^{\mathrm{a}}$. Irene de Araújo Machado, por todos os ensinamentos compartilhados durante esta jornada investigativa.

À colega de Mestrado, Erika Amaral, pela amizade e ajuda nos momentos mais difíceis de minha iniciação acadêmica.

Ao grupo Mirada - Estudos de Gênero e Audiovisual, pelo compartilhamento de ideias e de referências audiovisuais feministas.

À Escola de Comunicação e Artes, pela oportunidade de realização do curso de Mestrado. 


\section{SUMÁRIO}

Introdução: A jornada investigativa ................................................................... 06

Capítulo 1: A questão do empoderamento .......................................................................... 26

Capítulo 2: A proposta da emancipação ............................................................................... 43

2.1. A emancipação financeira pelo trabalho ............................................................ 47

2.2. A emancipação da dependência emocional relacionada à figura masculina ........ 64

Capítulo 3: O protagonismo como processo gradativo e contraditório ................. 78

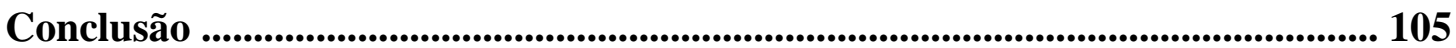

Referências bibliográficas ............................................................................... 109

Referências filmográficas .......................................................................................... 115

\section{LISTA DE IMAGENS}

Imagem 1 .............................................................................................................................. 52

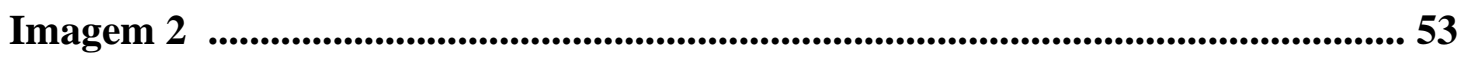

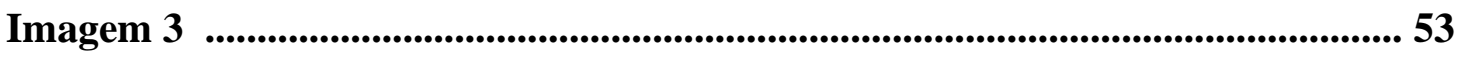

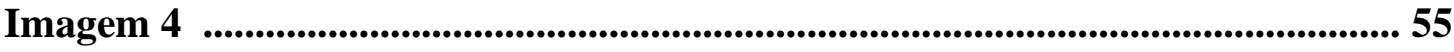

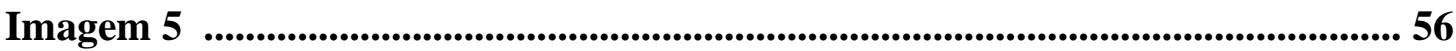

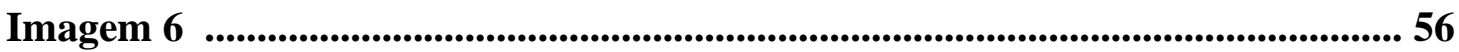

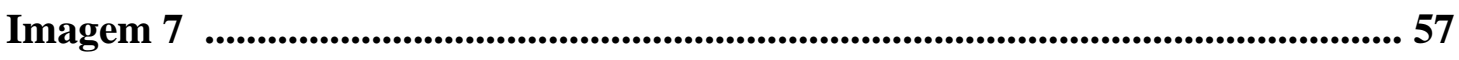

Imagem 8 ....................................................................................................................... 58

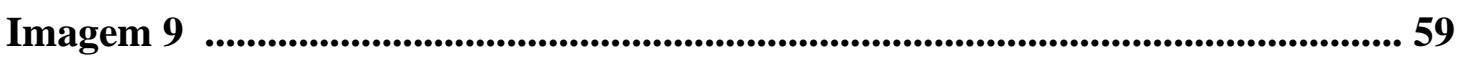

Imagem 10 ...................................................................................................................... 59

Imagem 11 ..................................................................................................................... 61

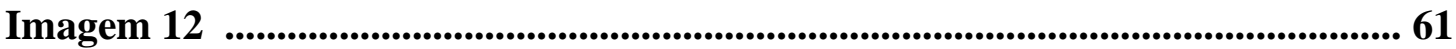

Imagem 13 .................................................................................................................................. 63

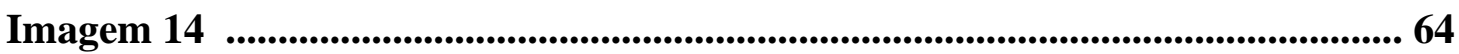

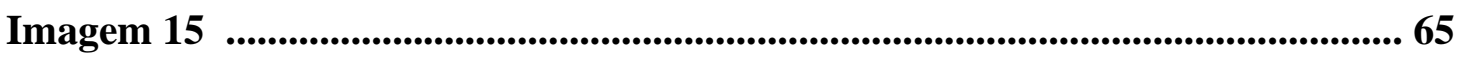

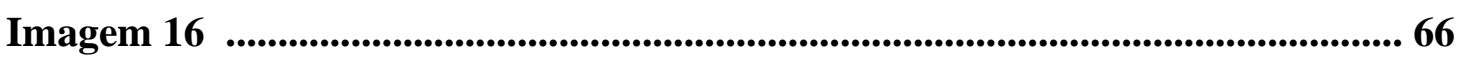

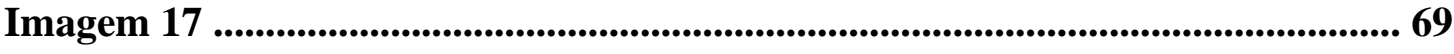

Imagem 18 ......................................................................................................................... 72 
Imagem 19 .......................................................................................................................................... 74

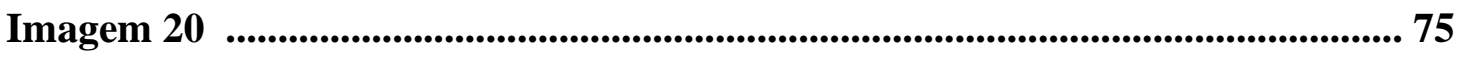

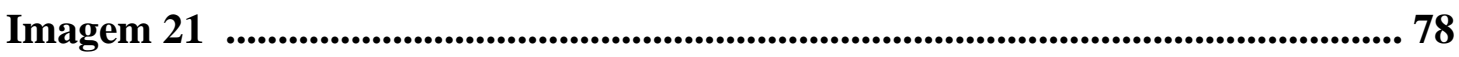

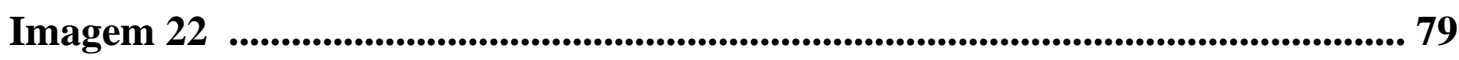

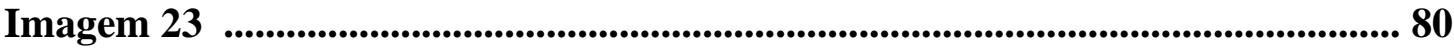

Imagem 24 ................................................................................................................................... 83

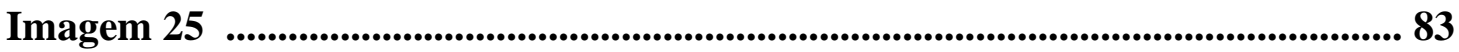

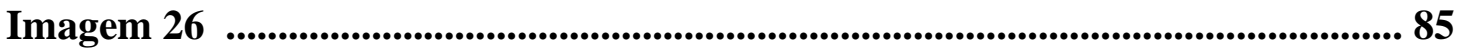

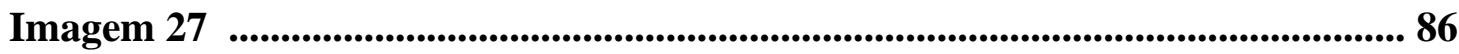

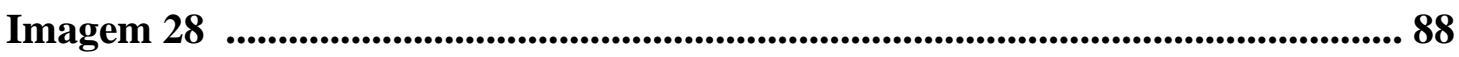

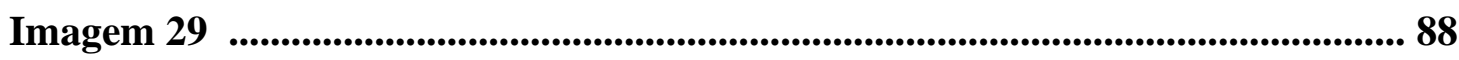

Imagem 30 ............................................................................................................................... 90

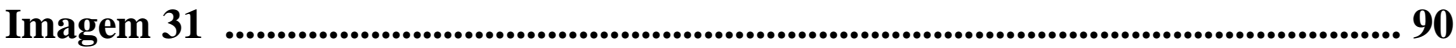

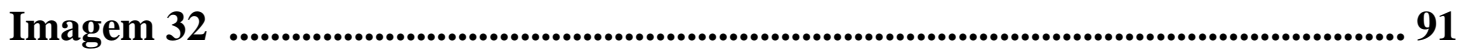

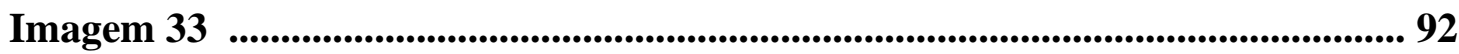

Imagem 34 ................................................................................................................................... 93

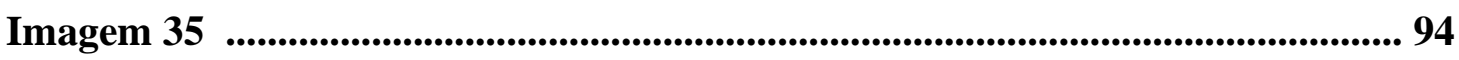

Imagem 36 ...................................................................................................................... 95

Imagem 37 ............................................................................................................................. 96

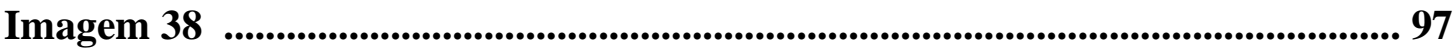

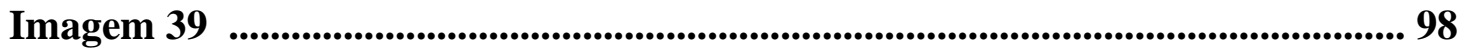

Imagem 40 .................................................................................................................................... 99

Imagem 41 ..................................................................................................................................... 100

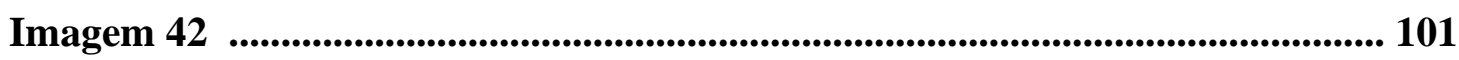

Imagem 43 ........................................................................................................ 102

Imagem 44 ........................................................................................................................... 104

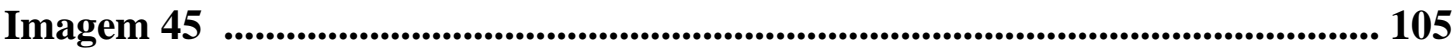

Imagem 46 ..................................................................................................................................... 106

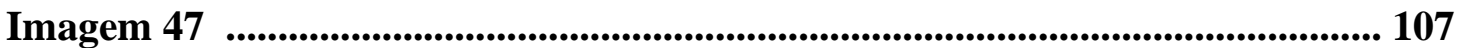




\section{RESUMO}

KREUTZ, K. A jornada das heroínas: protagonismo feminino no cinema contemporâneo brasileiro. 2020. Dissertação (Mestrado). Escola de Comunicações e Artes, Universidade de São Paulo, São Paulo, 2020.

O projeto busca estudar o protagonismo feminino na produção audiovisual brasileira contemporânea, mais especificamente nos filmes O Céu de Suely (2006), de Karim Aïnouz, Que Horas Ela Volta? (2015), de Anna Muylaert, e Pela Janela (2017), de Caroline Leone, tendo como ponto de partida a "jornada do herói”, de Joseph Campbell. A análise fílmica se debruça sobre elementos como o desenvolvimento das protagonistas, observando aspectos narrativos e visuais, para investigar de que modo a emancipação - financeira e da dependência masculina - pode ser uma ferramenta para completar a jornada heroica das personagens, a fim de obter verdadeiro protagonismo; tendo em vista que a vivência feminina, tanto no cinema quanto fora das telas, desenvolve-se de maneira diversa de modelos estabelecidos, apresentando gradações e desdobramentos únicos à realidade de cada mulher.

Palavras-chave: cinema brasileiro contemporâneo, protagonismo feminino, jornada da heroína 


\begin{abstract}
KREUTZ, K. The heroines' journey: female protagonism in Brazilian contemporary cinema. 2020. Dissertation (Master's Degree). Escola de Comunicações e Artes, Universidade de São Paulo, São Paulo, 2020.

The project studies female protagonism in the Brazilian contemporary film production, specifically the feature films Love for Sale / O Céu de Suely (2006), directed by Karim Aïnouz, The Second Mother / Que Horas Ela Volta? (2015), by Anna Muylaert, and A Window to Rosália / Pela Janela (2017), by Caroline Leone, taking Joseph Campbell's "hero's journey" as a starting point. The film analysis dwells on elements such as the main characters development, considering narrative and visual aspects, to investigate how their emancipation - both financial and from the male dependency - can be a way to complete the heroine's journey, in order to obtain real protagonism; taking into account that the female experience, in movies and in real life, diverges from established models with many levels of complexities that are particular to the reality of each woman.
\end{abstract}

Keywords: Brazilian contemporary cinema, female protagonism, heroine's journey 


\section{A JORNADA DAS HEROÍNAS: PROTAGONISMO FEMININO NO CINEMA CONTEMPORÂNEO BRASILEIRO}

\section{Introdução: A jornada investigativa}

Muito se tem discutido sobre o protagonismo feminino nos mais diversos âmbitos da sociedade, uma discussão que permeia cada momento desta jornada de pesquisa - desde a escolha do recorte temático, passando pela busca por referenciais bibliográficos até a análise fílmica. Na cultura ocidental, como um todo, o surgimento de questões sobre representatividade feminina tem conduzido a um posicionamento no que diz respeito a expandir as possibilidades narrativas de personagens femininas. No cinema brasileiro, em especial, a jornada de mulheres contemporâneas - heroínas que descobrem o papel de protagonistas em suas próprias histórias - pode contribuir no sentido de ampliar esse debate, abrindo caminhos para novos discursos.

O presente estudo se propõe a analisar as jornadas de três heroínas do cinema brasileiro Pós-Retomada: Hermila (interpretada por Hermila Guedes), protagonista do longametragem O Céu de Suely (2006), de Karim Aïnouz; Val (Regina Casé), protagonista de Que Horas Ela Volta? (2015), de Anna Muylaert; e Rosália (Magali Biff), protagonista de Pela Janela (2017), filme de Caroline Leone. As principais questões a serem investigadas dizem respeito ao protagonismo das personagens, que culminam na descoberta de sua própria autonomia para mudar a condição em que se encontram. Tomando como ponto de partida a “jornada do herói” (ou "monomito"”) - percurso de transformação de um personagem, analisado por Joseph Campbell em O Herói de Mil Faces (1949) e comumente utilizado em

\footnotetext{
${ }^{1} \mathrm{O}$ termo "monomito" foi cunhado por James Joyce, tendo aparecido inicialmente em Finnegans Wake (Nova York: Viking Press Inc., 1939, p. 581). A palavra se refere a uma jornada cíclica realizada por um herói mítico. Campbell era um estudioso e grande admirador do trabalho de Joyce.
} 
roteiros no cinema mainstream contemporâneo - pretende-se colocar em evidência um modelo revisto de jornada heroica, exclusivamente protagonizado por mulheres. A escolha desse arcabouço teórico, tão distante da realidade brasileira, deve-se essencialmente à experiência da pesquisadora como roteirista e seus questionamentos quanto a fórmulas narrativas consolidadas na indústria cinematográfica, principalmente a hollywoodiana.

Uma protagonista (do grego, protagonistes) é aquela que atua como personagem principal de uma história ou de um acontecimento, em torno da qual a trama se constrói. Embora o termo milenar, utilizado originalmente na dramaturgia e na literatura, tenha sido transposto para a linguagem audiovisual carregando sentido semelhante, no cinema o protagonismo tende a se revelar na análise do tempo em cena de uma personagem. Ou seja, considera-se protagonista a pessoa mais vista em tela no decorrer de um filme - um aspecto sobretudo quantitativo. Considerando esse ponto, insere-se aqui um dos questionamentos complementares ao presente esforço investigativo, que se interessa pela maneira como é apresentado e desenvolvido o protagonismo quando se trata de personagens femininas. Nesta pesquisa, portanto, busca-se ir além do aspecto quantitativo, investigando também os discursos narrativos e a linguagem estética que demonstram o protagonismo conquistado pelas personagens estudadas.

Devido a fatores históricos, durante vários séculos os protagonistas masculinos dominaram as narrativas cinematográficas da produção majoritariamente consumida no mundo - partindo de Hollywood, como padrão cultural de cinema predominante, e chegando ao cinema brasileiro, em particular. A “jornada do herói”, que se popularizou entre os profissionais de roteiro como uma espécie de fórmula, foi essencialmente fundamentada em uma figura heroica masculina. Nesta pesquisa, considerando que, em termos gerais, as mulheres ainda aparecem com menor frequência na posição de protagonistas de filmes, 
nacionais ou estrangeiros ${ }^{2}$, buscamos investigar se o protagonismo feminino se revela de maneira diferente daquela apresentada pelo herói clássico das jornadas formulaicas.

Em um ambiente cultural no qual são inegáveis tais disparidades, as revoluções do pensamento provocadas pelas diversas ondas do feminismo ajudaram a colocar em pauta também os aspectos qualitativos da representatividade das mulheres nas manifestações culturais. A contemporaneidade reforça a demanda por personagens que representem a condição feminina em suas múltiplas facetas, lutando por espaços nos quais a mulher possa, de fato, exercer um papel de destaque semelhante ao do homem na sociedade contemporânea - o que inclui, naturalmente, o protagonismo nas narrativas cinematográficas. Investigar essa representação feminina no cinema e refletir sobre ela, em especial no que concerne à produção audiovisual brasileira, apresenta-se como o objetivo deste projeto, que se concretiza na observação da jornada de protagonistas de filmes nacionais que conquistam - ou não - esse protagonismo no próprio espaço diegético, somada à análise da gradual construção desse protagonismo, quando conquistado.

Os primeiros passos desta jornada investigativa foram inspirados pelo longa-metragem Jogo de Cena (2007), do cineasta brasileiro Eduardo Coutinho, uma obra na qual realidade e encenação se entrelaçam de maneira sutil. No documentário, mulheres respondem a um anúncio e, no ambiente controlado de um teatro, contam aos realizadores do filme uma parte de suas histórias de vida. A fluidez entre ficção e não-ficção se dá pela orientação conceitual de caráter ensaístico do diretor, já que dezenas de mulheres responderam ao anúncio, mas apenas algumas dessas histórias reais aparecem na obra cinematográfica, em um processo de decupagem e de montagem que apresenta suas narrativas sob o véu da representação. Esses depoimentos foram posteriormente reencenados por atrizes - algumas delas conhecidas por

\footnotetext{
2 Para exemplificar a desproporção desses números, de acordo com dados do Sundance Institute e USC Annenberg Inclusion Initiative, dos 1.200 filmes mais assistidos entre 2007 e 2018, apenas 28\% foram protagonizados ou coprotagonizados por mulheres.
} 
seu trabalho na televisão e no cinema - em uma construção visual do ser mulher e da identidade feminina que embaralha o universo da representação e confronta estereótipos.

No longa-metragem de Coutinho, as conversas com as entrevistadas são estruturadas de modo a incluir o diretor e os espectadores no contracampo da interlocução, um processo que amplia o efeito dialógico desses registros. As histórias das mulheres representadas na tela são resultado de uma construção dramatúrgica que perpassa o trabalho de escolha das personagens e se estabelece na gravação audiovisual e na elaboração do roteiro, por meio da seleção das narrativas na montagem.

A maneira como se descortinam, no filme, as relações pessoais e familiares desse grupo peculiar de mulheres selecionadas, revela muito sobre o poder da dramaturgia para tornar audíveis vozes que frequentemente são ignoradas, transformando suas jornadas particulares e específicas em retratos da condição feminina em toda a sua amplitude - uma característica conceitual que instigou a presente pesquisa. Conforme declarou o documentarista, em entrevista a Mariana Simões para a Agência Pública (2014): "Não estou interessado em filmes políticos, sociais, genéricos. Nada que é genérico me interessa. Quero saber das pessoas que eu filmo, só”. Tal interesse é precisamente definido por Ismail Xavier, em sua análise a respeito da produção de Coutinho:

\footnotetext{
"No centro do seu método, está a fala de alguém sobre sua própria experiência, alguém escolhido porque se espera que não se prenda ao óbvio, aos clichês relativos à sua condição social. O que se quer é a expressão original, uma maneira de fazer-se personagem, narrar, quando é dada ao sujeito a oportunidade de uma ação afirmativa. Tudo o que da personagem se revela vem de sua ação diante da câmera, da conversa com o cineasta e do confronto com o olhar e a escuta do aparato cinematográfico.” (XAVIER, 2004, p. 51 e 52)
}

Esse movimento pela afirmação de personagens femininas é de grande interesse ao nosso estudo. No longa-metragem de Coutinho, as mulheres entrevistadas se apresentam não 
mais como objetos, mas como sujeitos, uma vez que seus dramas pessoais permitem construir representações em uma teia de sutilezas, que agrega memórias reais e experiências individuais às questões propostas pelo diretor. Esse processo se estabelece por meio do artifício cênico criado por Coutinho: ao filmar essas mulheres e ampliar suas vozes através do dispositivo fílmico, cada uma das personagens deixa de ser apenas objeto do filme e adquire a função de sujeito, assumindo o protagonismo do segmento no qual é retratada. As mulheres, assim, tornam-se elementos narrativos determinantes da ação, revelando-se em seus aspectos mais variados e profundos.

Ao se afastar do que é genérico, o cineasta apresenta as personagens de maneira tridimensional e afirmativa dentro de um aparato que, historicamente, não se destaca por permitir ao gênero feminino exercer esse papel. O observador se vê diante de um trabalho que envolve a exploração da dramaturgia audiovisual, em uma construção de sentidos que é tecida pela captação das imagens e das falas de atrizes e não atrizes, indistintas, criando um jogo de cena baseado em personagens femininas. Cada figura que ocupa a tela em Jogo de Cena, no momento em que sua história é contada, torna-se a protagonista do filme, passando de uma posição de obscuridade a um papel de destaque. Essa mudança de foco, que traz à tona personagens frequentemente apagadas pela sociedade, também dialoga com o objetivo desta pesquisa. Em um contexto temático - na arte em geral e no cinema em particular - no qual se observa a predominância de um olhar masculino sobre o ser mulher, percebe-se a necessidade da inserção de uma nova “jornada do herói” na construção narrativa cinematográfica; propondo, como mudança de paradigmas, a jornada das heroínas. Conforme defende Annette Kuhn:

"Uma preocupação comum entre representações feministas de todos os tipos e em todas as mídias é o desejo de desafiar modelos dominantes de representação. Essa preocupação tem como premissa a noção de que, em uma sociedade sexista, as mulheres não possuem linguagem própria e são, portanto, alienadas das formas de expressão 
culturalmente dominantes. Isso permite uma política de intervenção feminista no nível da linguagem e do sentido, a qual pode ser considerada como igualmente aplicável para a 'linguagem' do cinema propriamente dita e para a palavra escrita e falada." (KUHN, 1982, p. 167)

Dessa forma, o presente estudo, que se iniciou como uma jornada investigativa, evoluiu para uma jornada propositiva, voltando-se ao cinema brasileiro contemporâneo protagonizado por mulheres e colocando em pauta os movimentos diegéticos de autoafirmação dessas personagens. Para traçar um modelo de trajetória capaz de propor essas novas representações heroicas, fez-se necessário selecionar o corpus de pesquisa. Partiu-se, inicialmente, de uma compilação de mais de 40 obras cinematográficas de longa-metragem com protagonistas mulheres, produzidas por cineastas brasileiros no período denominado como Pós-Retomada, ou seja, a partir de 2003. Esse período, que se seguiu ao da Retomada (1992-2003), iniciou-se com a criação da Secretaria para o Desenvolvimento do Audiovisual, liberando recursos para filmes nacionais, com mecanismos de apoio à produção baseados em incentivos fiscais e em uma visão neoliberal de "cultura de mercado", cujos efeitos foram o aumento do número de filmes realizados e a possibilidade de uma "retomada" para o cinema brasileiro no cenário mundial (NAGIB, 2002).

Diante dessa quantidade expressiva de obras, com personagens dos mais variados perfis, optou-se pela análise do desenvolvimento e da construção interna de três protagonistas específicas - cujas jornadas envolvem temas universais, ilustrando um modelo revisto de trajetória das heroínas e trazendo novas abordagens teóricas, a partir da perspectiva da personagem feminina que assume o comando de sua história e de seu discurso. São essas reflexões e desenvolvimentos, tanto no sentido humano quanto estético, que transformam o final dos três filmes em verdadeiros recomeços. 
Os três longas-metragens selecionados para esse recorte - O Céu de Suely (2006), de Karim Aïnouz, Que Horas Ela Volta? (2015), de Anna Muylaert, e Pela Janela (2017), de Caroline Leone - destacam-se por apresentarem trajetórias e problemáticas de personagens que se complementam, em suas diferentes fases da vida, em um modelo de jornada das heroínas no qual as mulheres têm a chance de se descobrirem dentro de uma realidade em que podem, finalmente, intervir; escrevendo suas próprias histórias e mudando um destino prédeterminado. O não-protagonismo, nos três casos, apresenta-se majoritariamente pelas questões sociais, econômicas e emocionais estabelecidas pelo contexto no qual as personagens se encontram, ambientes esses que as privam da possibilidade de realizar o que desejam: Hermila deseja sair de Iguatu e buscar uma vida melhor no Sul; Val deseja se reconectar com a filha; Rosália deseja recuperar sua vontade de seguir em frente, após perder o emprego.

Com a definição dos objetos de pesquisa, fez-se necessário complementar as teorias de Campbell, desenvolvidas ao final da década de 1940, com estudos mais recentes sobre a representação das mulheres na cultura, em especial no meio cinematográfico. Verificou-se, portanto, o estado da arte no que diz respeito às teorias feministas aplicadas ao campo audiovisual. Nesse sentido, uma das primeiras referências conceituais foram as contribuições da norte-americana Molly Haskell. De acordo com a autora, as personagens femininas nos filmes tendem a ser percebidas em termos de papéis, estereótipos ou imagens, reproduzindo modelos ideológicos que garantem a manutenção de um sistema econômico estabelecido. Além disso, o amor romântico é o elemento estrutural das narrativas das personagens femininas, o que demanda a apresentação de novas formas de ver o mundo, colocando outro discurso imagético em circulação - um discurso que possa criar modelos de feminilidade atualizados e desconstruir tais estereótipos, retratando "imagens positivas" das mulheres no cinema (HASKELL, 1974). Ainda que a expressão “imagens positivas” seja bastante ampla e 
se encaixe de maneira diversa no contexto de diferentes países ou períodos históricos ${ }^{3}$, é importante observar que o cinema consumido de maneira predominante no Brasil contemporâneo tem como origem a produção estadunidense ${ }^{4}$, especificamente os filmes de longa-metragem produzidos por Hollywood (ANCINE, 2019). Portanto, a representação de personagens femininas do cinema dominante influencia, ainda que indiretamente, a maneira como são moldadas e representadas as protagonistas da produção cinematográfica nacional.

Diante de tal contexto, a investigação desta pesquisa se apresenta como uma proposta no sentido de contribuir para aprofundar os estudos de cinema brasileiro que busquem abranger a multiplicidade do ser mulher, colocando em perspectiva sua atual representação no cinema nacional, por meio da análise da jornada heroica de personagens que passam de uma situação inicial de não-protagonismo a um posicionamento central em suas histórias, em alguns casos se tornando sujeitos propositivos. Se, na construção dramática clássica, o homem comum se transforma em personagem evoluído por meio de seus atos heroicos, no caso da mulher as transformações se desdobram de maneira peculiar. O presente estudo investiga esses desdobramentos nos três filmes nacionais analisados, obras audiovisuais produzidas em um contexto de contemporaneidade no qual tais discussões não podem ser ignoradas. Em uma sociedade estruturalmente problemática, em que muitas mulheres ainda não encontram oportunidades para exercer verdadeira autonomia ${ }^{5}$, as representações de protagonismo se sobressaem, notadamente, pelo ato final de emancipação dessas personagens, que muitas vezes se revela como verdadeiro começo (ou recomeço) de suas narrativas. Quando as heroínas conquistam a chance de escrever suas próprias jornadas, por meio de um

\footnotetext{
${ }^{3}$ Sobretudo na análise das teorias de Haskell, que não contemplam pautas feministas de uma perspectiva interseccional, a respeito das quais os movimentos mais recentes têm se debruçado com maior abrangência.

${ }^{4}$ Conforme dados do Observatório Brasileiro do Cinema e do Audiovisual da Agência Nacional do Cinema ANCINE, cerca de $90 \%$ dos filmes assistidos pelo público brasileiro anualmente nas salas de cinemas são produções estrangeiras, predominantemente hollywoodianas.

${ }^{5}$ Segundo o filósofo Immanuel Kant (1724-1804), em Fundamentação da Metafísica dos Costumes (2007), a autonomia humana se caracteriza pela capacidade de se autodeterminar segundo uma legislação moral estabelecida pela própria vontade, livre de qualquer fator externo com influência subjugante.
} 
desenvolvimento interno, a trajetória do herói é reescrita, abrindo espaço para o protagonismo feminino; quando se tornam donas de suas narrativas, elas representam na tela do cinema um processo que ainda se encontra em fase embrionária, na vida real, tanto na esfera pública quanto privada.

O que se iniciou com a observação das personagens de Coutinho, sentadas em frente a uma câmera no ambiente de um teatro, resultou no contato íntimo da pesquisadora com três protagonistas que - uma vez examinadas - tornaram-se corporificações de dramas da condição humana; sobretudo, da condição feminina. O protagonismo das mulheres, seja ele no cinema nacional contemporâneo ou em qualquer outra manifestação artística, indubitavelmente ainda é um processo em construção. Contudo, arte e sociedade podem se cruzar, em uma via de mão dupla, para criar sentidos e promover reflexões sobre a existência feminina dentro dessa realidade em transformação.

Tendo em vista essa contextualização, qualquer análise do cinema protagonizado por mulheres, que tenha por objetivo identificar novas propostas de jornada heroica, deve necessariamente passar por uma revisão bibliográfica da teoria e crítica de cinema feminista. Contudo, considerando a amplitude e a complexidade de tal campo de estudos, a pesquisa dessa bibliografia buscou unicamente estabelecer um alicerce no qual pudessem ser inseridos os filmes estudados, em seu contexto histórico, social e cultural.

A teoria fílmica feminista despontou entre os anos 1960 e 1970, nos Estados Unidos, acompanhando a Segunda Onda do Feminismo ${ }^{6}$, com tentativas de análise iniciais baseadas

\footnotetext{
${ }^{6}$ A Primeira Onda do feminismo surgiu por volta do século XIX, com reivindicações pelo reconhecimento de direitos políticos, sociais e econômicos para as mulheres, marcadas pelos movimentos das proletárias e das sufragistas. A Segunda Onda feminista começa no início da década de 1960, partindo para uma perspectiva de isonomia material que pudesse proteger e libertar as mulheres, de modo que elas tivessem autonomia para decidir sobre sua vida e seu corpo. A Terceira Onda buscou desenvolver o próprio conceito de "mulher" enquanto categoria pretensamente universal, mas tendo em vista a presença de elementos diferenciadores, como classe e raça, reconhecendo as interseções entre marcadores de opressão. Atualmente vivenciamos a Quarta Onda, originada nos anos 1980, que aborda questões identitárias e de aceitação corporal, transgeneridade e masculinidade tóxica (HOLANDA, 2017).
} 
na teoria sociológica. À época, as análises incidiram em grande parte sobre a função das personagens femininas nas narrativas, embora também tenham abordado a participação das mulheres no mercado audiovisual, demandando representatividade nos meios de produção como forma de resistência, para criação de uma expressão autenticamente feminina. Obras como Popcorn Venus: Women, Movies, and the American Dream (1973), de Marjorie Rosen, e From Reverence to Rape: The Treatment of Women in Movies, de Molly Haskell (1974), buscaram analisar os estereótipos retratados nos filmes, verificando os diferentes estereótipos criados pelo cinema hollywoodiano e europeu através das décadas.

Dessa maneira, as teóricas feministas observaram que a mulher existia na cultura patriarcal somente como o significante do outro masculino. Especificamente no cinema, esse aspecto se mostrava em um processo ligado a mecanismos inconscientes de construção das imagens. A figura feminina aparecia nos filmes (como ainda aparece) como mero objeto, já que o prazer visual - especificamente no cinema - seria construído para o público masculino, sendo ele o que vê e a mulher a que é vista, de modo que "a cisão entre espetáculo e narrativa apoia o papel do homem como o ativo para levar a história adiante. O homem controla a fantasia do filme e também emerge como representante do poder em um sentido mais amplo: como o portador do olhar do espectador." (MULVEY, 1979). Naturalmente, tais proposições deram subsídio a embates ideológicos buscando desconstruir um sistema falocêntrico ${ }^{7}$, atacando as manifestações da opressão feminina em suas raízes mais profundas.

Já nos anos 1980, a teórica italiana Teresa de Lauretis ampliou o questionamento das representações da mulher como imagem e espetáculo ou como objeto para ser observado, sendo seu corpo unicamente local de sexualidade e de prazer visual (LAURETIS, 1984). A

\footnotetext{
${ }^{7} \mathrm{O}$ termo que coloca o falo como referencial e valor significativo universal passou a ser empregado a partir dos anos 1920, referindo-se a pontos de vista centrados na perspectiva masculina. A lógica fálica ganhou destaque principalmente devido à teoria psicanalítica de Sigmund Freud (1856-1939). O falocentrismo passou a representar uma convicção de superioridade, baseada no modelo de sexualidade masculino, sendo considerado incompleto tudo o que se afastasse desse paradigma. (BIRMAN, 2001)
} 
autora apresentou, ainda, uma teoria sobre tecnologia de gênero. Segundo ela, gênero, "como representação e como autorrepresentação, é produto de diferentes tecnologias sociais, como o cinema, por exemplo, e de discursos, epistemologias e práticas críticas institucionalizadas, bem como práticas da vida cotidiana” (LAURETIS, 1994, p. 208). Portanto, operar essas tecnologias seria uma das formas de trabalhar a construção de identidades, uma vez que é precisamente através das tecnologias de gênero que se processam a regulamentação e a normalização de estruturas ideológicas nas quais a imagem representada da mulher é estereotipada.

Ainda que os tempos sejam outros e muito se tenha obtido no campo das lutas minoritárias, inclusive acrescentando às pautas feministas questões relativas a sexualidade e raça, é inegável a existência - ou a permanência - de um cinema dominante patriarcal e cerceador, que estabelece uma clara dicotomia entre o papel da mulher e o do homem no cinema. "O olhar masculino determinante projeta sua fantasia na figura feminina, estilizada de acordo com essa fantasia." (MULVEY, 1983, p. 444). Em grande parte das narrativas do cinema mainstream ainda é o homem quem faz a história acontecer, dentro de um modelo de discurso que recusa e/ou silencia as diferenças. Nesse contexto, a figura feminina é constantemente representada na ficção em posições de passividade. Essa mulher como imagem silenciosa, em um cinema dominado por uma visão masculina, baseia-se em idealizações limitadas e parciais do feminino, já que se trata de uma projeção moral e social estigmatizada por conceitos arcaicos que prejudicam tanto homens quanto mulheres no que diz respeito a exercer seu protagonismo, uma vez que imobilizam também o ser masculino em um papel de herói infalível, impedido de expressar vulnerabilidades.

Uma possível mudança nessa trajetória se daria com o deslocamento da perspectiva falocentrista dominante, de modo que a mulher (como personagem exercendo um protagonismo verdadeiro) pudesse atuar segundo sua visão de mundo, suas percepções, 
intuições, seus sonhos e fantasias, por meio de um cinema feito por mulheres. Para a teórica Annette Kuhn, autora de Women's Pictures: Feminism and Cinema (1982), o primeiro passo na concretização do protagonismo feminino no cinema seria compreender as estruturas que sustentam a indústria e gerar oportunidades de atuação para as mulheres em uma área na qual por muito tempo elas se sentiram, e de fato foram, excluídas.

“[...] fui surpreendida pela espantosa e de certa forma alarmante percepção de que em todos os meus anos de arrebatada cinefilia, minha fruição dos filmes tinha dependido em grande parte da identificação com personagens masculinos. Ou seja, eu tinha me colocado no lugar do homem, do herói, para poder aproveitar - talvez até mesmo compreender - os filmes. Isso me pareceu nada menos do que uma negação da parte de mim mesma que via os filmes como mulher." (KUHN, 1982, prefácio, IX)

Kuhn relata que, enquanto buscava desesperadamente por modelos positivos de representação feminina, teve sua experiência fílmica transformada pela perspectiva feminista, que passou a informar a maneira como enxergava os filmes e analisava as mulheres retratadas nas telas, questionando sua posição histórica subjugada na sociedade. Desse modo, o protagonismo feminino de personagens ativas, cujas ações as posicionam como sujeitos de suas próprias histórias, poderia servir como vivência transformadora para as realizadoras e produtoras culturais - abrindo caminhos para o protagonismo de diretoras, roteiristas, diretoras de arte e de fotografia, etc. -, mas, sobretudo, para as espectadoras. É evidente que um aparato cinematográfico de construções ideológicas obsoletas e estruturas engessadas, nas quais não há espaço para a investigação do ser mulher, entra em direta contradição com o mundo contemporâneo, por isso a necessidade de um reposicionamento.

A questão passa a ser de que maneira realizar esse projeto de cinema sob uma ótica feminina. "O feminismo não inventou apenas novas estratégias ou criou novos textos, mas, mais importante, concebeu um novo sujeito social, as mulheres: como oradoras, escritoras, 
leitoras, espectadoras, consumidoras e produtoras de modelos culturais" (LAURETIS, 1985, p. 163). O desafio encontra-se, justamente, em construir esses novos sujeitos, para substituir os que dominaram a cultura por tantos séculos.

Considerando que o protagonismo muitas vezes negado às personagens femininas perpassa questões sociais e culturais, já que grande parte da tradição narrativa ficcional da cultura ocidental é fundamentada em figuras heroicas masculinas, esta pesquisa centrou seus esforços não em refletir sobre a ausência ou a invisibilidade das mulheres no audiovisual, mas em analisar a presença de protagonistas femininas no cinema brasileiro e sua própria existência como alternativa para essa viabilização de novas jornadas.

É importante ressaltar que os três filmes estudados - O Céu de Suely, Que Horas Ela Volta e Pela Janela - não são necessariamente feministas. Mais mulheres na produção não garante filmes mais feministas; especialmente enquanto permanecerem inalteradas as raízes estruturais do machismo na sociedade. Ademais, um corpus de análise composto apenas por longas-metragens dirigidos por mulheres seria uma forma de reiterar a concepção um tanto quanto simplista de que um cinema feminista ou conectado às causas femininas deva ser feito - única e exclusivamente - por cineastas mulheres.

Embora uma breve análise da filmografia contemporânea brasileira indique que as diretoras do sexo feminino estejam, em geral, mais atentas às questões de gênero e suas implicações, isso não significa que cineastas homens sejam incapazes de levar às telas personagens femininas de igual complexidade. É possível considerar ainda que a sexualidade de Karim Aïnouz (de O Céu de Suely), um cineasta declaradamente homossexual, tenha expandido sua sensibilidade a respeito de outras lutas por igualdade de direitos e de oportunidades. Fundamentalmente, porém, são relevantes as experiências e a formação do profissional como indivíduo: um diretor ou diretora de cinema precisa, sobretudo, exercitar uma visão complexa do mundo. Portanto, o foco desta seleção de longas-metragens - 
dirigidos por Karim Aïnouz, Anna Muylaert e Caroline Leone - apoiou-se na maneira como as protagonistas foram desenvolvidas, de modo a criar novas heroínas com possibilidades transformadoras de jornadas. O objetivo, aqui, é estabelecer conexões entre as obras apresentadas, buscando similaridades entre os processos dramáticos, ainda que ressaltando as características únicas de cada produção.

O caminho analítico apontado pelos estudos da teoria de cinema feminista segue uma lógica de abertura para toda e qualquer realização fílmica que apresente trajetórias diversas e inclusivas. A jornada feminina, aqui, não abrange a trajetória de um dia - com início, meio e fim bem definidos, como manhã tarde e noite. Indubitavelmente, abrir espaço para o protagonismo feminino no cinema, reescrevendo a "jornada do herói” não é tarefa simples ou livre de questionamentos. Trata-se de um trajeto longo e repleto de curvas, no qual alguns trechos encontram-se iluminados e outros obscuros. Novos olhares são necessários, colocando em foco personagens femininas que possam servir de modelos para essa jornada ainda em construção.

"A mulher é, quase sempre, coadjuvante. De um modo geral, o protagonismo feminino em narrativas fílmicas é fortemente marcado por definições misóginas do papel que cabe às mulheres na sociedade; casar-se, servir ao marido, cuidar dos filhos, amar incondicionalmente. Mulheres livres, fortes e independentes são frequentemente apresentadas como masculinizadas, assexuadas, insensíveis e traiçoeiras. São comuns as situações em que elas atuam como o elemento desestruturante, como a força de ruptura na narrativa." (DUARTE, 2009, p. 46-47)

De acordo com Teresa de Lauretis, a figura feminina é apresentada no cinema como objeto de desejo ou como obstáculo a ser superado. No que diz respeito ao primeiro aspecto, a estrutura se aproxima do mito de Édipo ${ }^{8}$. Diversos filmes seguem uma trajetória edipiana, em geral apresentando um indivíduo-herói do sexo masculino, o qual embarca em uma jornada

${ }^{8}$ O personagem Édipo, da mitologia grega, é famoso por matar o pai e casar-se com a própria mãe. 
que irá envolver a passagem por uma fronteira e o ingresso em um 'outro espaço' (LAURETIS, 1984, p. 119). Esse sujeito heroico (comumente) masculino é, de fato, o participante ativo da história, enquanto a mulher se resume a um elemento narrativo secundário.

Embora os mitos que deram origem à "jornada do herói” de Campbell tenham sido criados como fundamento de uma cultura dominante, alicerçada pela exploração econômica, eles também surgiram para organizar a complexidade dos atos humanos. O que a teoria feminista propõe é ultrapassar as mitologias fundamentadas em opressão, indo em direção à resistência histórica e criando o que poderia ser chamado de "contra-mito" (MULVEY, 1989, p. 173). Sobre essa forma de reescrever as estruturas históricas que no passado oprimiram, para buscar por meio delas uma redenção, assim escreve Roberta Veiga:

"Se a mulher foi apartada da história, o cinema, ao reinscrevê-la ao lado de outros sujeitos condenados pelos dispositivos de poder, reescreve o próprio devir histórico. Não se trata de desfazer o dano do passado, mas de redimir sujeitos ordinários do apagamento histórico, oferecendo a redenção por outra forma de sobrevivência, a da imagem. 'Sem dúvida, somente a humanidade redimida poderá apropriar-se totalmente do seu passado', diz Benjamin (1994, p. 223)." (VEIGA, 2017, p. 228)

Ou seja, o mesmo cinema que tanto objetificou a figura feminina pode se tornar uma possibilidade de manifestação artística que a liberta para ser quem ela é, de fato: um ser complexo e multifacetado. Por esse motivo, a presente pesquisa buscou analisar o desenvolvimento e a construção interna de três protagonistas femininas - Hermila, Val e Rosália - cuja jornada envolve temas universais, ilustrando um modelo revisto de trajetória heroica e apresentando mulheres que se encaminham a uma apropriação de suas narrativas.

Contudo, para apreender as reflexões humanas e estéticas em $O$ Céu de Suely, Que Horas Ela Volta? e Pela Janela, é preciso analisar detalhadamente os desafios e as 
experiências que cobram atitudes e levam as protagonistas a tomarem as rédeas de suas histórias; conquistando, por fim, a denominação de heroínas. $\mathrm{Na}$ "jornada do herói” de Campbell, o autor apresenta seu conceito de heroísmo aplicado à psicologia da trajetória humana; assim, o herói é o homem ou mulher que conseguiu vencer suas limitações históricas, pessoais e geográficas. De acordo com a investigação do autor, "o percurso padrão da aventura mitológica do herói é uma magnificação da fórmula representada nos rituais de passagem: separação-iniciação-retorno, que podem ser considerados a unidade nuclear do monomito" (CAMPBELL, 1949, p. 17). As visões, ideias e inspirações desses personagens heroicos são como espelhos dos pensamentos humanos; por isso, falam com eloquência da fonte inesgotável por meio da qual a sociedade renasce. "O herói morreu como homem moderno; mas, como homem eterno - aperfeiçoado, não específico e universal -, renasceu" (CAMPBELL, 1949, p. 13).

Embora seja apresentado como um ser "não específico", "homem ou mulher", Campbell partia de um universo cultural centrado nas experiências narrativas masculinas. Posteriormente, uma de suas alunas, a psicóloga norte-americana Maureen Murdock, desenvolveu A Jornada da Heroína: A Busca Feminina por Plenitude (1990), obra na qual a autora questiona as teorias de seu mentor. No entanto, não cabe ao presente trabalho estabelecer juízos de valores com relação à obra de Campbell, uma vez que suas teorias estão circunscritas a um período histórico no qual as bandeiras feministas estavam apenas iniciando seu levante - assim como não se pode cobrar tais posicionamentos das narrativas heroicas mitológicas, das histórias medievais ou dos contos de fadas. O objetivo, neste caso, é o de utilizar seus conceitos para nortear a construção de uma nova jornada, mais dinâmica e inclusiva, que possa integrar de maneira orgânica as pautas da atualidade no que diz respeito à presença feminina na cultura, notadamente no cinema. 
Em sua obra, Campbell sintetizou os conhecimentos obtidos por meio de comparações de mitos e lendas de diversas culturas. A “jornada do herói” foi sua metáfora para a trajetória interior que os personagens heroicos das mais variadas épocas e locais compartilham, um caminho que os leva através de uma série de passos envolvendo separação, decadência, sofrimento e, por fim, um retorno. Todavia, as jornadas que acompanham personagens femininas - em especial, quando elas são protagonistas - tendem a carregar um grau de complexidade que vai além da fórmula de superação de conflitos para atingir a glória final. Ainda que a estrutura em três atos seja a linha elementar básica de um roteiro de ficção que segue uma perspectiva linear - como é o caso de O Céu de Suely, Que Horas Ela Volta? e Pela Janela - o desenvolvimento se dá de maneira imprevisível e inusitada, abrindo espaço à sensibilidade e à criatividade.

Tradicionalmente, as narrativas de ficção do cinema que se baseiam na "jornada do herói” envolvem um problema central, ou uma questão dramática que desestabiliza o chamado "mundo comum". A partir desse momento, o herói ingressa em um "mundo especial" para resolver o conflito e recuperar o equilíbrio. São duas realidades que se contrastam e que obrigam o sujeito a enfrentar dificuldades, que consequentemente o levarão a um crescimento pessoal.

A função primária da mitologia e dos ritos sempre foi a de fornecer os símbolos que levam o espírito humano a avançar, opondo-se às outras fantasias humanas que tendem a atrasar sua evolução - como as neuroses, complexos e fixações infantis não exorcizadas. A saída do "mundo comum" e as travessias dos chamados "limiares" são passagens necessárias da vida adulta.

Seguindo os passos da jornada heroica de Campbell, o primeiro ponto da narrativa seria o chamado à aventura. No caso de Hermila, em $O$ Céu de Suely, embora seja claramente a protagonista do filme, ela não é a protagonista de sua própria história, já que se encontra 
presa e uma vida que não escolheu, de fato, para si. Suas amarras são, sobretudo, financeiras; uma vez que é abandonada pelo marido, com um filho para cuidar, em uma cidade sem perspectivas. Em Que Horas Ela Volta?, a personagem Val se encontra tão imersa nas demandas da família para a qual trabalha, reproduzindo dinâmicas de uma herança colonialista, que simplesmente colocou em segundo plano suas próprias necessidades. Já Rosália, em Pela Janela, tem como protagonista de sua vida o trabalho - algo que ela acaba perdendo, fato que se torna o motivo de sua apatia e melancolia com relação ao futuro.

Nas três narrativas, o chamado à aventura é um verdadeiro caminho sem saída. As personagens são apresentadas como seres coadjuvantes, invisibilizados e imobilizados, cujos sonhos e necessidades foram colocados em segundo plano. Não há possibilidade de recusa ao chamado ou de fuga à realidade que lhes é imposta. Tampouco há um encontro com o mentor, como ocorreria na "jornada do herói”, ou a orientação de qualquer figura representativa de sabedoria. O encontro, para essas personagens femininas, é com desafios que as forçam a sair de um mundo comum de passividade, no qual seu protagonismo não se manifesta. A sabedoria para lidar com as circunstâncias adversas precisa surgir delas mesmas.

O cruzamento do primeiro limiar, na jornada das heroínas, envolve o início da libertação das estruturas patriarcais e o autodescobrimento como ser heroico, capaz de superar os obstáculos por conta própria, evolução essa que levará as personagens a um processo de emancipação humana. Inseridas em trajetórias pré-determinadas por fatores externos, alheios à sua vontade ou planejamento, as mulheres entram em conflito com um mundo que rejeita seu anseio por autonomia.

Por isso, o segundo ato da jornada dessas protagonistas é o ponto de desenvolvimento de sua dimensão humanista, como seres conscientes de seu lugar no mundo: sujeitos de seus atos, de seus sonhos, de seus erros e acertos. Nesse ponto da trajetória, enquanto o herói de Campbell se depara com testes, aliados e inimigos, preparando-se para a aproximação da 
caverna, dentro da qual passará por provações, para finalmente obter sua recompensa, as heroínas lutam para se desprender das pequenas prisões que encarceram o ser mulher, neste mundo. Ao mesmo tempo em que a “jornada do herói” reforça o mito, a jornada das heroínas busca desmistificar o que é conhecido como ser heroico.

Para a construção interna das personagens, o foco do desenvolvimento está no combate à condição de inferioridade e de passividade que lhes foi imposta. No caso de Hermila, seu processo de emancipação interno - que envolve rifar o próprio corpo, assumindo a identidade de Suely, como forma de obter independência financeira e realizar o objetivo de sair de sua cidade natal, Iguatu - gera incompreensão e julgamento das pessoas que a cercam. Para Val, a jornada de autodescoberta provoca conflitos com o sistema trabalhista opressor no qual se encontra. Rosália, por sua vez, encara a mudança como algo doloroso e precisa compreender que "sair da caverna" pode ser uma opção viável, libertadora. No entanto, a recompensa dessas heroínas não é fácil, simples ou imediata, como aquela muitas vezes concedida ao herói tradicional.

A travessia do segundo limiar, para o herói de Campbell, marca o final da jornada: o protagonista toma a estrada de volta para casa, depara-se com um último teste (a ressurreição) e retorna com o elixir ao seu mundo, o que comprova a superação do desafio. Para as heroínas, a hipótese a ser investigada no terceiro ato dos filmes analisados diz respeito ao momento de resolução das histórias como início de novas possibilidades, mais fluidas, traçadas pelas próprias personagens em seu espaço diegético. Cabe à análise verificar se há, de fato, um enfrentamento dessas protagonistas quanto à passividade em suas vidas, vislumbrando trajetórias ativas, verdadeiramente transformadoras. Desse modo, pretende-se investigar se os filmes do corpus estudado apresentam uma mudança na jornada tradicional, tendo como hipótese a questão de que o terceiro ato não oferece resoluções, mas novos conflitos e novas perspectivas, conforme buscaremos demonstrar a partir da análise fílmica. 
Segundo Campbell, o "herói é o homem da submissão autoconquistada. Mas submissão a quê? Eis precisamente o enigma que hoje temos de colocar diante de nós mesmos. Eis o enigma cuja solução, em toda parte, constitui a virtude primária e a façanha histórica do herói” (CAMPBELL, 1949, p. 12). A mulher, submetida à condição de passividade durante tantos séculos, dá os primeiros passos rumo à libertação de seu discurso talvez fragmentado, ainda em construção, porém sensível e transgressor. Um discurso de resistência, no qual a reflexão fílmica é a apresentação da consciência de si mesmo.

Portanto, através da análise fílmica, os próximos capítulos pretendem traçar uma jornada comum entre as heroínas dos três longas-metragens selecionados, reescrevendo a “jornada do herói” proposta por Joseph Campbell. Para essa reflexão, tomaremos como aspectos de estudo a mise-en-scène, a montagem, a direção de arte e de fotografia, a sonoplastia e a trilha musical, além de outras características - tanto estéticas quanto narrativas - das obras audiovisuais.

Para as protagonistas estudadas nesta pesquisa, a jornada se inicia em situações de não-protagonismo e privação de autonomia, nas quais elas são colocadas perante obstáculos e expectativas frustradas. No desenvolvimento de cada uma de suas jornadas, as personagens descobrem - ou não - o protagonismo no espaço diegético, para serem então capazes de buscar uma libertação de seus contextos opressores. A parte final da jornada das heroínas seria o momento em que as protagonistas veriam para si mesmas uma possibilidade de recomeço. Ao descobrirem seu protagonismo, poderiam finalmente iniciar a reescrita de suas histórias; agora, sim, em verdadeira posição de protagonismo. 


\section{Capítulo 1: A questão do empoderamento}

Nos filmes estudados, a relação que as personagens desenvolvem consigo mesmas, ao longo de suas jornadas, é a de descoberta. Descobrir, em si mesmas, o poder de decidir e de agir, a despeito das circunstâncias externas, é uma questão que se apresenta duplamente desafiadora para as mulheres: primeiro, porque elas são condicionadas desde a infância a compreenderem tudo o que não podem fazer; segundo, porque no momento em que se dispõem a contrariar essa estrutura pré-estabelecida de limitações, qualquer ação visando ao empoderamento $^{9}$ tende a gerar reações veementes no sentido de reprimir tal tomada de poder.

Em nossos objetos de estudo, se existe alguma possibilidade de empoderamento, ela é muitas vezes obstruída por questões sociais ou financeiras, enfrentadas no cotidiano de Hermila, Val e Rosália. As três protagonistas possuem demandas e insatisfações - muitas vezes reprimidas - relativas à condição de protagonismo em suas próprias vidas; no entanto, ao que se observa inicialmente, parecem distantes de alcançar, de fato, o poder de reescreverem suas histórias.

O fato de as três personagens não se enquadrarem, em primeira instância, naquilo que se definiria como "empoderadas", coloca em xeque a abrangência desse conceito para a análise à qual nos propomos. No mundo contemporâneo, a questão do empoderamento tem sido discutida e reverberada de maneira quase exaustiva, quando se trata de temas feministas. Contudo, o que se define como empoderamento não é livre de contradições e ambiguidades, tampouco se adequa às realidades de todas as mulheres, em seus diversos contextos sociais e pessoais. Carece, portanto, de uma análise mais profunda, já que segue racionalidades

\footnotetext{
${ }^{9}$ Neologismo consignado no Dicionário de Língua Portuguesa Contemporânea das Ciências de Lisboa e registrado no Mordebe - Base de Dados Morfológica do Português, tem suas origens no termo anglicano empowerment e significa obtenção, alargamento ou reforço de poder.
} 
econômicas e políticas; embora o termo seja frequentemente empregado com o intuito de abarcar todo e qualquer avanço no que concerne à atuação da mulher na sociedade.

A construção do conceito de empoderamento - atualmente, tão polissêmico - tem suas raízes na luta pelos direitos civis, principalmente a partir da segunda metade do século XX, relacionada a grupos discriminados socialmente e excluídos de processos decisivos da vida social. Na década de 1980, popularizou-se como caráter sígnico por meio da teoria do psicólogo norte-americano Julian Rappaport, segundo o qual "empoderamento [empowerment] é visto como um processo: o mecanismo pelo qual pessoas, organizações e comunidades ganham controle sobre suas vidas" (RAPPAPORT, 1984). De acordo com essa perspectiva, transformar o cidadão comum em sujeito ativo seria uma forma de gerar uma sociedade mais saudável e participativa.

Enquanto o conceito norte-americano valoriza a transformação do indivíduo, os educadores Paulo Freire e Ira Shor trouxeram à realidade latino-americana o empoderamento como construção da classe trabalhadora por meio do despertar de uma consciência crítica. Segundo os estudiosos, ao tomarem conhecimento do poder que usufruem em suas relações cotidianas, instigados a perceber e a exercitar esse poder, os cidadãos seriam capazes de ampliá-lo para conquistarem sua libertação das classes dominantes (FREIRE; SHOR, 1986). O empoderamento, nesse sentido, tornar-se-ia não somente um processo individual, mas um ato social. Ou seja, uma pessoa ou instituição empoderada seria aquela que realizaria, por si mesma, as mudanças e ações que a levariam a evoluir e se fortalecer.

Como podemos observar, as influências teóricas sobre o tema são diversas, principalmente advindas dos contextos europeu e anglo-saxônico, mas via de regra se referem ao processo não linear, gradual e dialético de desenvolvimento de relações econômico-sociais que permitem inverter dinâmicas de opressão, discriminação ou dominação social, sejam elas interpessoais ou institucionais (VASCONCELOS, 2003). Nesse contexto, o termo 
empoderamento - como é aplicado na contemporaneidade - diz respeito sobretudo ao poder que se desenvolve ou é adquirido por pessoas, seja através de si mesmas ou com a ajuda de outrem; podendo se referir tanto a um processo ou esforço quanto a um resultado ou conquista, em sua habilidade de influenciar o mundo (STAPLES, 1990). Por conseguinte, o empoderamento tem assumido significações relacionadas ao acesso à informação, à ampliação da percepção dos indivíduos sobre si mesmos e ao desenvolvimento de potencialidades, em busca de uma participação real na sociedade, que possibilite exercer a democracia (BAQUERO, 2001).

No âmbito da vida social e política, o empoderamento como fortalecimento de indivíduos ou grupos seria uma forma de impulsionar a melhoria em suas condições de vida. Esse processo pode ocorrer por meio de mobilizações e práticas que visem a aumentar a autonomia dos sujeitos oprimidos socialmente. Pode ainda se referir a iniciativas que promovam a integração dos excluídos, carentes e demandatários de bens elementares à sobrevivência, assim como o estímulo a serviços públicos (GOHN, 2004), como ações ou programas de cunho social.

Por estar inserido em uma dinâmica sociopolítica e econômica, o empoderamento, no presente contexto, não consegue escapar da relação com o capitalismo e a cultura de consumo. A sociedade neoliberalista ajudou a moldar uma narrativa de empoderamento feminino, subordinando o ideal de emancipação das mulheres à acumulação de capital, subentendendose dessa lógica que a pobreza por si só seria um aspecto desempoderador e excludente. A questão financeira e econômica se tornou fundamental, nesse sentido, já que ao longo das últimas décadas as mulheres se tornaram força de trabalho representativa e adquiriram uma parcela de poder - neste caso, essencialmente o poder de compra - com o qual não contavam, ou sobre o qual não possuíam completa autonomia, anteriormente. No entanto, empregado de maneira leviana, o termo empoderamento pode transmitir a ideia de que, com o ingresso no 
mercado de trabalho, a mulher se libertou, automaticamente, de todas as estruturas de dominação que lhe eram e ainda são impostas socialmente - o que não é verdadeiro, principalmente na realidade brasileira.

Não nos cabe afirmar que a falta de autossuficiência econômica é o único fator responsável pelo que se vê como desempoderamento feminino. Em muitos casos, a dependência da mulher ao homem foi substituída pela dependência com relação ao emprego, agravada pelo fato de que, para exercer esse suposto poder adquirido, ela passou a trabalhar não apenas um, mas vários turnos; agregando às tarefas domésticas, no papel de esposa e/ou mãe, as obrigações laborais. Além disso, a inserção da mão de obra feminina no mercado de trabalho se deu de maneira assistemática, frequentemente sem abordar questões como a educação, o voto e as capacidades civis da mulher, que possibilitariam a essas trabalhadoras uma real independência do sistema que as oprime.

De acordo com Herriger, renunciar ao estado de dependência e de impotência transforma os indivíduos em sujeitos ativos, autônomos e autodeterminados, que lutam por si mesmos e tomam a direção da vida nas próprias mãos (HERRIGER, 1997), em um movimento de protagonismo na luta por justiça social. Mas simplesmente escapar de uma situação de risco social por meio de agentes externos ou de recursos materiais, embora seja um dos caminhos para o empoderamento, não é o único. Partindo desse pressuposto, o termo empoderar pode ser relacionado à condução de um sujeito por diferentes estágios de autoafirmação, produzindo transformações por meio de movimentos internos. Esses estágios envolveriam o entendimento da condição desses indivíduos na sociedade e a percepção do que se passa ao seu redor (BERTH, 2018). Entretanto, essa compreensão somente se realiza quando tornada ação, já que o poder é um exercício e existe apenas em ato, na relação com o outro (ou outros). 
"Os processos de empoderamento ocorrem em arenas conflitivas, onde necessariamente se expressam relações de poder, as quais devem ser encaradas não como algo estanque e determinado, mas plástico, flexível, portanto modificável pela ação-reflexão-ação humanas, na medida em que os indivíduos compreendam sua inserção histórica passada, presente e futura e sintam-se capazes e motivados para intervir em sua realidade." (KLEBE, WENDAUSEN, 2009)

A partir dessa exposição, torna-se possível vislumbrar alguns dos conceitos referentes ao empoderamento na literatura das mais diversas disciplinas, como a sociologia, a economia, a filosofia e a ciência política. De maneira sucinta, o termo tem sido empregado tanto no sentido de fortalecimento da esfera privada quanto como reforço de um espaço público em que são alteradas as relações de poder - seja o poder material, seja simbólico -, por vezes, sendo relacionado também à noção de equidade, já que a mulher parte de uma posição de pressuposta inferioridade dentro das estruturas patriarcais ainda vigentes em diversos países do mundo, inclusive no Brasil.

Tendo em vista essas definições, consideramos relevante aprofundar tal análise, inserindo como contraponto nas discussões sobre empoderamento outro conceito, o da emancipação $^{10}$, talvez mais abrangente no que diz respeito à conquista do protagonismo pelas mulheres, rompendo com os fatores que as impedem de obter realização individual. Na realidade contemporânea, em que se vivencia uma busca crescente por transformações, a emancipação do indivíduo sofre uma bifurcação bem definida entre vida social e identidade pessoal; permitindo que ele exerça sua liberdade para buscar propósito, realização e plenitude.

Considerando que a emancipação pode ser interpretada como um requisito para a tomada de decisões e, consequentemente, a conquista do que compreendemos como protagonismo, passaremos à análise das obras de longa-metragem que compõem o presente estudo. Em suas jornadas, cada uma das personagens vivencia diferentes estágios do processo

10 "Tornar livre, independente" (Houaiss, 2001), cujas raízes (do latim, èx manus capere) significam "soltar da mão". 
emancipatório: Val é uma empregada doméstica que se encontra em uma dinâmica trabalhista problemática e busca se reconectar com a filha, a qual vê com olhos críticos a condição subjugada da mãe; Hermila é uma moça abandonada por seu grande amor em uma cidade sem perspectivas, que sonha em escapar dessa realidade opressiva; Rosália é uma mulher madura, que basicamente vive em função do trabalho, mas se encontra desnorteada e melancólica ao ser desligada da empresa. Cada qual em sua trajetória particular, as protagonistas dos três filmes seguem por caminhos incertos, que podem - ou não - levá-las a uma condição de verdadeiro protagonismo no espaço diegético.

Maureen Murdock, autora de A Jornada da Heroína, fundamenta a proposição dessa perspectiva emancipatória que buscamos consolidar no que diz respeito ao protagonismo no cinema contemporâneo brasileiro. Para ela, trata-se de uma busca única da mulher por propósito em um contexto na qual ela é constantemente comparada - e definida - por valores e padrões masculinos. Segundo a psicóloga,

"As mulheres têm uma missão neste momento, na nossa cultura. É a missão de abraçar totalmente sua natureza feminina, aprendendo a valorizar a si mesmas como mulheres e a curar a ferida profunda do feminino. É uma jornada interna muito importante para se tornarem seres humanos plenamente integrados, equilibrados e completos. Como a maior parte das jornadas, o caminho da heroína não é fácil, não tem direções bem definidas ou guias de localização reconhecidos. Não há mapas, cartas náuticas ou idade cronológica para iniciar. Não há linhas retas. É uma jornada que raramente recebe validação do mundo externo; na verdade, ele frequentemente a sabota e interfere nela." (MURDOCK, 1990, p. 3)

Para Joseph Campbell, cujo modelo de trajetória heroica, descrito em O Herói de Mil Faces (1949), foi referência fundamental para o trabalho de Murdock, na linguagem pictórica da mitologia a mulher representa "a totalidade do que pode ser conhecido" (CAMPBELL, 1949), já que ela encarna a figura da deusa - com a qual o encontro é o teste final do talento 
na aventura do herói. Entretanto, o autor ressalta que o mito é formulado em termos amplos, como referência a uma fórmula humana geral, válida tanto para homens quanto mulheres.

"O herói é aquele que aprende. À medida que ele progride, na lenta iniciação que é a vida, a forma da deusa passa, aos seus olhos, por uma série de transfigurações: ela jamais pode ser maior que ele, embora sempre seja capaz de prometer mais do que ele já é capaz de compreender. Ela o atrai e guia e lhe pede que rompa os grilhões que o prendem. E se ele puder alcançarlhe a importância, os dois, o sujeito do conhecimento e o seu objeto, serão libertados de todas as limitações. A mulher é o guia para o sublime auge da aventura sensual. Vista por olhos inferiores, é reduzida a condições inferiores; pelo olho mau da ignorância, é condenada à banalidade e à feiura. Mas é redimida pelos olhos da compreensão. O herói que puder considerá-la tal como ela é, sem comoção indevida, mas com a gentileza e a segurança que ela requer, traz em si o potencial do rei, do deus encarnado, do seu mundo criado." (CAMPBELL, 1949, p. 6566)

Considerando a diversidade de experiências do ser feminino em relação ao masculino, cabe observar que nem todos os elementos simbólicos da jornada do herói de Campbell se aplicam, de forma prática, à condição da mulher no mundo e ao seu protagonismo (ou falta de) nas narrativas literárias e cinematográficas ocidentais. Idealmente, a protagonista/heroína seria aquela que adota medidas práticas que a aproximem de seus mais profundos anseios, identificando uma jornada evolutiva que depende exclusivamente de si mesma e, portanto, compreendendo a necessidade de ser independente.

Aplicando esse conceito diretamente às ações das personagens dos filmes estudados, no início da jornada vemos nuances desse processo sobretudo em Val. No primeiro ato de Que Horas Ela Volta?, em diversas ocasiões a doméstica demonstra seu descontentamento no que diz respeito à relação com a filha, Jéssica (interpretada por Camila Márdila) - ou, mais precisamente, à falta de um relacionamento mais próximo. Ela expressa, em diversas cenas, o desejo de se reconectar com a garota. Contudo, neste ponto, a possibilidade de se emancipar (principalmente das estruturas laborais questionáveis em que se encontra) ainda é apenas um 
vislumbre. Para ser concretizada, necessitará da presença física de Jéssica - esta, sim, uma personagem consciente de suas decisões e surpreendentemente avançada no caminho de uma emancipação concreta, cujo ponto de vista divergente ao mesmo tempo desafia e auxilia Val a concretizar sua jornada. A reconexão entre as duas representa a cura da ferida aberta pela separação que havia ocorrido ainda na infância da menina. Sobre tal cisão, Em Women, Earth and Spirit: The Feminine Symbol and Myth (1984), Helen Luke aborda a significante diferença entre as experiências mãe/filho e mãe/filha:

"Em um nível arquetípico, o filho carrega para a mãe a imagem da jornada interior dela, mas a filha é a extensão de seu próprio ser, trazendo-a de volta ao passado e à sua própria juventude, e para a frente rumo à promessa de seu próprio renascimento em uma nova personalidade, dentro da consciência do Ego." (LUKE, 1984, p. 54)

Hermila, por outro lado, inicia sua jornada alienada e apegada a um relacionamento amoroso ilusório, tendo seus anseios calcados no mito do amor romântico e acreditando que o outro (marido ou filho) completará sua vida, atualizando seu destino por ela. Na primeira parte de sua jornada, verifica-se que ela vivencia um processo de ruptura que lhe apresenta a possibilidade de mudança, no momento em que se vê desamparada financeiramente e encontra na venda de rifas uma forma de obter recursos para sobreviver; embora a personagem não apreenda, de imediato, as implicações dessa mudança em sua vida. Seu contexto, neste ponto, é ainda distante de uma consciência da própria realidade, o que se evidencia quando a jovem insiste na tentativa de contatar o parceiro que a abandonou, telefonando repetidamente $-\mathrm{e}$, a cada fracasso, passando a enxergar a verdadeira natureza do homem em quem depositou sua confiança e seus planos para o futuro.

Usando como comparativo a etapa denominada “A Estrada de Provações”, na jornada desenvolvida por Maureen Murdock, esse estado de espera é uma condição para a qual as mulheres são treinadas e preparadas, na sociedade patriarcal. "Ela é uma mãe amamentando 
seu bebê recém-nascido, enquanto espera o marido voltar do trabalho. Ele é a conexão dela com o mundo exterior. Ele toma conta de tudo. Ela está esperando que a vida comece" (MURDOCK, 1990, p. 57). Dessa forma, Hermila representa a mulher que deseja ou se identificar com o masculino, ou ser resgatada por ele.

Embora a personagem Val não se enquadre nessa mesma definição, já que não existe qualquer conexão romântica (seja concreta ou em potencial) para a personagem na história, no início de sua jornada ela é a própria encarnação da mulher servil, cuja função principal é atender às necessidades alheias e colocar seus próprios anseios em segundo plano, como se a aceitação do outro - um outro que ocupa posição de superioridade na cadeia hierárquica social - fosse mais importante do que sua própria realização individual. Murdock bem expressa esse comportamento:

"Enquanto aprendem a antecipar as necessidades dos outros, elas esperam - consciente ou inconscientemente - que suas necessidades também sejam antecipadas e supridas. Quando uma mulher descobre que suas demandas não são consideradas, ela sente que algo está errado consigo mesma. Ela pode até mesmo sentir vergonha por ter necessidades também." (MURDOCK, 1990, p. 49)

Sobre essa mesma questão, em Mulheres em Terapia, Harriet Lerner escreve:

"Inerente à postura passivo-dependente de muitas mulheres está a motivação inconsciente de apoiar e proteger outra pessoa, assim como a convicção inconsciente de que deve permanecer em uma posição de relativa fraqueza para que seus relacionamentos mais importantes sobrevivam. Até mesmo mulheres intelectualmente liberadas sentem, inconscientemente, medo e culpa com relação a 'ferir' os outros, especialmente homens, quando exercem plenamente suas capacidades de pensamento e ação independentes. De fato, mulheres que passam a definir mais claramente os termos de suas próprias vidas, frequentemente são acusadas de diminuir os homens, magoar as crianças ou de alguma forma agirem de maneira destrutiva com os outros." (LERNER, 1990, p. 162, apud MURDOCK, 1990) 
Em outro ponto, completamente diverso, do processo emancipatório, está a personagem Rosália. Se a emancipação está relacionada à consciência de seu estar no mundo, em função das relações externas - neste caso, sociopolíticas - ela demonstra, durante boa parte do filme, o quanto era dependente de uma rotina laboral, uma vez que sua relação com o mundo se dava quase que exclusivamente através do trabalho. A personagem não sai da empresa em que trabalhava por conta própria, nem embarca em uma viagem para a Argentina com o irmão José (interpretado por Cacá Amaral) porque se emancipou, mas simplesmente porque foi mandada embora do emprego e praticamente coagida a viajar. Sem os vínculos afetivos que se percebem em Val e Hermila, por exemplo, Rosália se encontra inicialmente mergulhada no cotidiano vazio e sem perspectivas de seu trabalho, tendo sido forçadamente removida dessa alienação de maneira inesperada. Neste ponto, mesmo sofrendo as mudanças, ela se mostra incapaz de percebê-las em sua totalidade, ou mesmo de reagir a elas. Seu estado de apatia e silêncio durante um trecho significativo do caminho rumo a Buenos Aires reforçam o quanto essa mulher se sentia dependente das estruturas que a mantinham submissa e que a relegavam ao mero papel de operária; não um sujeito, mas uma engrenagem dentro de um sistema de produção.

Diferentemente das duas outras personagens estudadas, Val passa a perceber, gradualmente e por meio da influência da filha (que entra na história como agente catalisador de revoluções), as relações e os conflitos presentes no universo em que está inserida. Sua percepção das desigualdades culmina em um processo de tomada de consciência sobre si própria e sobre seu lugar no mundo. Inicialmente, é um choque para ela aceitar os pensamentos e as atitudes insubordinadas da filha. A personagem chega a criticar e desestimular os comportamentos e posturas que ela vê como sinais de desobediência e desacato à ordem instituída. Não se trata apenas de rebeldia adolescente, mas de uma jovem que não reconhece "seu lugar" naquela estrutura social, tampouco age de acordo. 
Em diversos momentos do filme, essa característica contestadora de Jéssica é apontada por outros personagens. Fabinho (Michel Joelsas), o filho da patroa Bárbara (Karine Teles), julga a moça como "estranha", por ser "segura demais de si". A própria Val chama a atenção da filha em inúmeras ocasiões, lamentando o fato de ela não ter "noção de nada". Para a doméstica, a jovem parece vir de "outro planeta" por não reconhecer as estruturas hierárquicas da casa; o que deveria ser sua obrigação como subalterna, uma vez que "a pessoa já nasce sabendo o que pode e o que não pode". Afinal, "onde já se viu filha de empregada sentar na mesa dos patrões". O que Jéssica se recusa a reconhecer ou aceitar é a suposta superioridade desses patrões perante ela, primeiramente por não trabalhar para eles, mas sobretudo por não se considerar nem permitir ser tratada como "uma cidadã de segunda classe". Nas palavras da personagem: "Não me acho melhor, não. Só não me acho pior. É diferente."

Para Val, acostumada a viver no contexto de servir sem questionar, compreender que Jéssica pode estar certa é um processo que lhe custa um pouco. No entanto, quando o conflito ideológico entre as duas gerações ameaça se tornar um motivo para que a mãe perca novamente a filha que está começando a reconquistar, a personagem se abre aos questionamentos, observando de maneira crítica as diferenças de classes que a colocam em uma posição subalterna, dentro de sua delicada condição trabalhista.

Como um reflexo da não aceitação da filha a esse lugar de inferioridade, relegado à empregada que "é quase da família", a consciência de Val a respeito de sua situação se expande. Consequência disso é a progressiva rejeição da personagem às regras e estruturas hierárquicas da casa, que ela havia respeitado durante anos - um exemplo claro dessa rebeldia adquirida no contato com Jéssica é a cena em que Val entra na piscina, território proibido para os funcionários. Ao experimentar romper as normas implícitas de não usufruir do que pertence à família da patroa, Val não apenas quebra voluntariamente um acordo silencioso, como sente prazer no ato de desobediência. Ela passa a agir conscientemente, em um 
enfrentamento da instituição que separa patrões e empregados, decisão que mais à frente pode levá-la à emancipação.

Um mito dos antigos sumérios, citado por Campbell em O Herói de Mil Faces (1949), ilustra de maneira precisa essa dualidade de sentimentos - misto de culpa e satisfação presente no ato de rebeldia de Val:

"Inana e Ereshkigal, as duas irmãs, luz e trevas respectivamente, representam, juntas — nos termos da antiga simbologia - a mesma deusa dividida em dois aspectos; seu confronto resume todo o sentido do difícil caminho de provas. O herói, deus ou deusa, homem ou mulher, a figura de um mito ou o sonhador num sonho, descobre e assimila seu oposto (seu próprio eu insuspeitado), quer engolindo-o, quer sendo engolido por ele. Uma a uma, as resistências vão sendo quebradas. Ele deve deixar de lado o orgulho, a virtude, a beleza e a vida e inclinarse ou submeter-se aos desígnios do absolutamente intolerável. Então, descobre que ele e seu oposto são, não de espécies diferentes, mas de uma mesma carne." (Campbell, 1949, p. 61)

Contrapondo a esse processo a narrativa de Rosália, verifica-se que ela ainda está muito distante da conscientização sobre seu ser no mundo. A personagem não se emancipou de sua rotina como operária, ela foi demitida - ou seja, deslocada da atividade por vontade de outrem. Esse acontecimento provoca uma ruptura tão profunda de sua visão de si mesma que a reação da personagem é simplesmente não responder, em um estado duradouro de "anestesia". O deslocamento, aqui, é um fator interessante para pensar a emancipação da personagem, porque foi uma fragmentação do mundo de Rosália que permitiu a ela observar a si mesma "de fora da janela". No mercado de trabalho, a mulher perde seu valor como força de trabalho e, consequentemente, deixa de se sentir como um sujeito útil para a sociedade. "O ser requer aceitar a si mesma, permanecer dentro de si mesma e não fazer nada para se provar. É uma disciplina que não recebe aplausos do mundo externo, que questiona a produção por seu próprio interesse." (MURDOCK, 1990, p. 128) 
Não apenas seu contexto de tomada de consciência é diferente e apresenta um processo significativamente mais lento, saindo do estado de choque com a ajuda do irmão e com a vivência de uma "aventura" em terras desconhecidas, como seu pano de fundo se mostra menos otimista com relação ao futuro: se a inserção no mercado de trabalho não é fácil ou promissora para uma jovem como Hermila, como poderá se encaixar nessa sociedade uma mulher acima dos 50 anos? Aqui, entram problemáticas como o sacrifício de si mesma pelos outros e o mito de não ser suficiente, em estruturas opressoras muitas vezes autoimpostas pelo próprio oprimido. As mulheres não aprendem os passos para se tornar heroínas, apenas aprendem a fingir que são heroicas.

\begin{abstract}
"Quando a heroína diz não à próxima tarefa heroica, há extremo desconforto. A alternativa para o heroísmo é a autoindulgência, a passividade e a falta de importância. Isso significa morte e desespero na cultura atual; nossa cultura apoia o caminho da conquista de posição: mais, melhor, mais rápido. A maior parte das pessoas receiam que o oposto dessa hubris seja a invisibilidade e não sabem o que fazer. Quando uma mulher para de fazer, ela deve aprender simplesmente a ser. Ser não é um luxo, é um rigor. A heroína deve ouvir atentamente sua verdadeira voz interior. Isso quer dizer silenciar as outras vozes ansiosas para dizer a ela o que fazer. Ela deve estar disposta a suportar a tensão até que sua nova forma surja. Menos do que isso aborta o crescimento, nega a mudança e reverte a transformação. O ser demanda coragem e sacrifício." (MURDOCK, 1990, p. 83)
\end{abstract}

Já em $O$ Céu de Suely, a personagem enfrenta julgamentos não somente por não fazer o que se é esperado dela (abraçar incondicionalmente o papel de mãe), como por ser diferente do que as bases moralistas de sua comunidade determinam (optando pela prostituição para realizar um objetivo material - o que resulta em outra forma de submissão, uma vez que se entregar para a satisfação sexual do outro apenas a torna mais objetificada). Apesar desse embate para ser dona de suas próprias decisões, o amadurecimento de Hermila não chega a se expressar, de fato, no decorrer da história. Aos poucos, conforme vai tomando conhecimento da situação em que o parceiro a colocou, ela muda seu comportamento de expectativa 
romântica para uma espécie de revanchismo com relação à figura masculina que a abandonou. Ao longo de sua jornada, são diversos os exemplos de momentos em que a personagem age por rancor ou instinto. A maneira como lida com o filho, demonstrando certa rejeição ao dever da maternidade, é um dos exemplos de sua natureza revoltada com o papel social que lhe foi imposto. Inserindo-a na jornada de Campbell, Hermila é uma mulher que não aceita a figura mitológica da Mãe Universal, que exigiria dela uma presença nutridora e protetora; isto é, não se encaixa no paradigma do que a sociedade espera dela. No estágio de sua jornada que aborda a "Separação do Feminino", Murdock discorre sobre essa questão:

"Muitas mulheres têm medo do termo feminino. Ele se tornou uma palavra corrompida. Algumas sentem que, inerente à definição, está a obrigação de tomar conta dos outros. A sociedade tem encorajado as mulheres a viverem através dos outros, ao invés de buscarem sua própria realização." (MURDOCK, 1990, p. 23)

A busca de Hermila por uma suposta libertação acaba sendo efetivada por meio do sexo - seja no relacionamento casual com o ex-namorado, João (interpretado por João Miguel), seja na ambígua decisão de rifar seu corpo. Ainda que ela pareça mais conectada com essa parte de si mesma do que Rosália, por exemplo, a personagem não expressa de maneira positiva o senso de poder conectado à sua sexualidade. Certamente há um processo emancipatório brotando, nas pequenas atitudes da personagem que desafiam o que é considerado "de bom tom" no contexto social em que está inserida, mas a cena que conclui o filme não pode ser identificada como um ponto final do processo - pelo contrário. Ela está distante de chegar à total autonomia porque, em sua juventude e imaturidade, não vivenciou ainda situações que pudessem levá-la ao nível de consciência necessário para se libertar. Hermila não apresenta uma noção clara das implicações que estão em suas ações e gestos, como seria esperado em um processo de conscientização sobre o próprio papel no mundo. 
No caso de Val, a filha (que é aprovada em uma universidade e que está prestes a ingressar em um nicho intelectual elitizado) passa a atuar como uma chama propulsora da explosão de consciência. Ademais, quando Val descobre em Jéssica uma mulher que, assim como ela, também é mãe, mas que nem por isso desistiu de lutar por sua carreira e de seguir sua vocação, algo se transforma dentro da protagonista de Que Horas Ela Volta?. Dentre as personagens estudadas, pode-se afirmar que ela é a única que vislumbra uma possibilidade concreta de mudança para um contexto de verdadeiro protagonismo. De empregada doméstica, irá se tornar uma pequena empresária. Pedindo o desligamento do emprego, também se mostra capaz de abandonar sua zona de conforto; até porque, ao contrário das outras duas, possui uma reserva financeira que lhe permite sustentar essa decisão. A filha Jéssica, por sua vez, é uma mulher extremamente emancipada e esclarecida para sua idade, tendo transmitido para a mãe sua clareza de pensamento sobre as relações sociais. Ela também sabe lidar com os avanços masculinos indesejados, sem se corromper - como demonstra nas interações com os personagens masculinos da família empregadora de sua mãe. Jéssica é um prenúncio do nível de conscientização em que Val também pode chegar, já que a personagem tem essa potência.

Uma característica determinante das jornadas das heroínas dos três filmes analisados, que as diferenciam de maneira abismal das fórmulas estruturais desenvolvidas por Campbell e Murdock, é o fato de não apresentarem uma estrutura narrativa engessada ou dividida em estágios claramente definidos. São histórias em que o processo das personagens é fluido e, por vezes, incompleto ou desequilibrado. No entanto, alguns dos passos de ambas as jornadas (do herói e da heroína) são observados no material da pesquisa. Um desses aspectos é "A Iniciação e a Descida da Deusa". Nessa fase, segundo Murdock, "as mulheres encontram seu caminho de volta para si mesmas". A autora afirma que tal movimento não acontece para cima e para fora, como seria natural de uma jornada masculina, mas para baixo, em direção às 
profundezas de seu próprio ser. "Sua metáfora de cavar a terra para encontrar o caminho de volta a si mesma expressa o processo de iniciação da mulher." (MURDOCK, 1990, p. 89)

Esse movimento do exterior para o interior é também a proposta da escritora Kim Hudson na obra A Promessa da Virgem (2009). A autora reescreve o mito da missão heroica dando a ele novas formas, com base em arquétipos jungianos e em padrões encontrados nos contos de fadas. Nessa jornada, a virgem não é o ideal romântico de um herói, mas a protagonista de sua própria história. Enquanto o herói é um jovem (não necessariamente do sexo masculino) que deixa seu mundo comum em uma aventura, para posteriormente retornar a ele, a virgem é a jovem (não necessariamente do sexo feminino) que deve encontrar sua identidade em um caminho que a leva para longe do confinamento de casa, transformando a si mesma e ao seu reino. Nessa proposta, a protagonista é ao mesmo tempo transgressora e transformadora.

Quando a estrutura narrativa da jornada do herói ou da heroína é decodificada para a experiência humana, a trajetória não se apresenta linearmente - com começo, meio e fim bem definidos -, mas sob uma perspectiva circular. Assim, a tarefa do herói, nas histórias contemporâneas, configura-se como uma busca individual e constante.

"Por isso é tão necessário redefinir herói e heroína nas nossas vidas, atualmente. A missão heroica não diz respeito ao poder sobre algo, mas à conquista e à dominação; é uma missão para trazer equilíbrio às nossas vidas pela combinação de ambos os aspectos feminino e masculino. A heroína dos tempos modernos precisa confrontar o medo de recuperar sua natureza feminina, seu poder feminino, sua habilidade de sentir, de curar, de criar, de mudar estruturas sociais e moldar seu futuro." (MURDOCK, 1990, p. 129)

Na dinâmica entre os três filmes, destaca-se, sobretudo, a diversidade de histórias e estágios de realização. $\mathrm{O}$ fato de que as personagens se encontram em diferentes esquadros de suas jornadas pessoais reflete a amplitude de gradações envolvidas no processo individual de cada mulher, em busca do protagonismo na própria vida - muitas vezes, sequer dando-se 
conta desse processo. O desenvolvimento de três seres humanos tão diversos em seus olhares e discursos representa a multiplicidade de opções possíveis para a jornada das heroínas contemporâneas. Nem todas estão no mesmo nível, nem todas conquistaram ou irão conquistar sua liberdade. Talvez nunca consigam ser donas de sua própria conduta, verdadeiras autoras de suas ações. Especialmente quando as opressões são financeiras, adquirir a segurança para tomar decisões como o sujeito de sua história requer esforço. A jornada é sempre a mesma, mas cada mulher tem suas particularidades e enfrenta desafios próprios. Aqui, as diferenças falam mais do que as semelhanças, porque expressam a complexidade e a sutileza da condição feminina no mundo. 


\section{Capítulo 2: A proposta da emancipação}

As protagonistas dos três longas-metragens estudados (Que Horas Ela Volta?, O Céu de Suely e Pela Janela), cada qual em sua jornada, vivenciam diferentes estágios de um processo emancipatório; que será observado na sequência, tomando como ponto de partida modelos de estrutura narrativa como a "jornada do herói”, organizada por Joseph Campbell (1949) e ampliada posteriormente por Christopher Vogler (1992), assim como a "jornada da heroína", proposta por Maureen Murdock (1990), e a "promessa da virgem”, elaborada por Kim Hudson (2010).

O conceito da emancipação, sugerido aqui como alternativa ao termo empoderamento, para abarcar os desenvolvimentos e evoluções vivenciados pelas personagens femininas no contexto da contemporaneidade, compreende a transformação da realidade por meio de uma tomada de consciência, abarcando significados como liberdade, rompimento, independência e conquista - um sentido transformador que está relacionado à evolução humana. No entanto, diz respeito menos às relações sociais e mais à liberdade para tomada das próprias decisões, pela capacidade do sujeito de interferir nos processos que determinam sua vida.

A superação de uma condição opressora e a concretização da autonomia podem se manifestar das mais variadas formas: um trabalho que tenha sentido e propósito, a realização de um desejo pessoal, a autonomia sobre as decisões sociais, o acesso à informação e à educação. São, por conseguinte, condições que permitem ao indivíduo tornar-se sujeito de sua narrativa - um sujeito consciente e autônomo. No caso das mulheres, são instrumentos indispensáveis para exercer protagonismo.

A conscientização, aqui, não se apresenta no sentido de manipular ou de conduzir o outro a pensar de determinada maneira, mas de "tomar posse do real", permitindo constituir um olhar crítico sobre a realidade. Conforme afirmou Paulo Freire, mudamos nossa 
consciência na medida em que estamos iluminados a respeito dos conflitos reais da história. Provém dessa necessidade de iluminação o conceito da educação libertadora para a compreensão da realidade; o qual, na concepção freireana, não é um processo de natureza individual, mas um ato social (FREIRE, 1986).

No sentido político, o conceito de emancipação se origina do esforço de indivíduos desprovidos de protagonismo para obter igualdade e direitos econômicos, sociais e políticos. Seria, assim, o resultado de uma revolução política. No ensaio Sobre a Questão Judaica (1844), Karl Marx relaciona o termo a uma posição igualitária de cidadãos individuais perante a lei, com relação ao Estado, independentemente de sua religião, de suas propriedades ou de outras características privadas. De acordo com o filósofo, a emancipação no sentido cívico e político, no que concerne ao cidadão como elemento integrante do Estado e com relação ao seu governo, representa um progresso; contudo, não é a etapa final da emancipação humana, apenas a etapa final dentro do contexto da ordem social vigente (MARX, 1844).

"O homem individual e real deve levar o cidadão abstrato de volta a si mesmo e, como um indivíduo em sua vida empírica, em seu trabalho e relacionamentos individuais, tornar-se um serespécie; o homem deve reconhecer suas próprias forças como forças sociais, organizá-las e, enfim, não mais separar as forças sociais de si mesmo na forma de forças políticas. Apenas quando isso for alcançado a emancipação humana estará completa." (MARX, 1977, p. 64).

Partindo dessa afirmação, a ideia de emancipação na teoria política vem sendo compreendida como um processo de racionalização envolvendo a promoção de direitos humanos ou a superação histórica do capitalismo. Também remete à independência política de um estado ou país, que concede ao território emancipado o poder de se autogerir, podendo seus cidadãos tomarem as decisões políticas e administrativas pertinentes. $\mathrm{Na}$ esfera individual, segundo o Código Civil brasileiro, em termos legais a emancipação é um ato jurídico que concede ao menor de 18 anos a liberdade para exercer certos atos civis, podendo 
ministrar seus bens e negócios sem a tutela dos pais. Uma autonomia que, etimologicamente, remete ao poder de dar a si mesmo a própria lei. Não se trata, porém, de um poder absoluto e ilimitado, mas restrito à esfera particular.

Historicamente, a emancipação feminina representou um processo no qual estratégias e esforços foram despendidos por mulheres para se livrarem da autoridade e do controle masculino dentro das estruturas de poder tradicionais, assim como uma luta para garantir iguais direitos e oportunidades (direitos legais e políticos, direito à propriedade, direito à educação, direito sobre a própria reprodução, igualdade no trabalho), abolindo leis, instituições e padrões de comportamento que promovessem a discriminação de gênero. Ainda no século XIX, Friedrich Engels, em A Origem da Família, da Propriedade Privada e do Estado (1884), já entendia que a emancipação da mulher somente seria possível quando ela fizesse "parte da produção em uma escala social ampla e o trabalho doméstico [tomasse] apenas uma parte insignificante de seu tempo." Tal processo permeia a compreensão da natureza da subordinação da mulher - especialmente a maneira como ela é naturalizada e, muitas vezes, institucionalizada - e de sua restrição a determinados espaços ou papéis, questionando as desigualdades de poder e, sobretudo, propondo soluções.

Nesse sentido, pode-se entender a emancipação como o processo de libertação que se amplia para a vida social, no qual os sujeitos constituem formas de ser e de estar no mundo, exercendo autonomia sobre suas vontades. Segundo Gadotti (1992, p. 155), "a tomada de consciência não é suficiente. É preciso que ela seja acompanhada de uma ação sobre si mesma e sobre o mundo [...], isto é, de intervenção na sociedade e na natureza, tentando ultrapassar seu inacabamento". Para Zitkoski (2008, p. 215), “somos seres do inédito viável, pois ainda não somos totalmente prontos, viemos nos fazendo na história e podemos sempre nos reinventar seguindo a busca por mais humanidade". A essência desse processo está no 
domínio consciente de sua autoconstrução (Tonet, 2005), já que ele não ocorre sem que seja precedido pelo autoconhecimento e pela idealização de um propósito.

Dentro dessa conjuntura, a emancipação pode ser vista como um processo envolvendo três estágios distintos, porém interconectados: um rompimento na continuidade da história; uma luta política para concretizar uma visão utópica criada em virtude disso; e um possível entendimento entre os participantes de uma discussão. Assim, abafar ou negligenciar esforços coletivos de emancipação pode levar, em última instância, a uma sociedade caracterizada pela dependência em instituições ou aprisionada em sistemas previamente estabelecidos, estruturalmente falhos. $\mathrm{O}$ ativismo feminino sob uma perspectiva emancipatória, portanto, tende a caminhar em sentido oposto a essa estagnação.

Sob leis dominadas pelo patriarcado, no ocidente, até algumas décadas atrás, as mulheres possuíam poucos ou nenhum direito, estando submetidas ao controle de maridos ou familiares do sexo masculino - o que, em alguns locais, ainda ocorre. Há países onde os direitos civis femininos são protegidos por lei e pela cultura local; por outro lado, há também os que negligenciam ou ignoram essas demandas. A noção de emancipação como ruptura de uma hierarquia de dominação, desse modo, pode ser interpretada como a possibilidade de escolher por conta própria sua ocupação e estilo de vida, sem que haja interferência do Estado ou de estruturas sociais no que diz respeito a essas escolhas.

Por isso, o conceito de empoderamento, quando colocado em oposição à emancipação, levanta questionamentos. Na realidade contemporânea, a defesa de processos emancipatórios nos âmbitos social e econômico coloca o desenvolvimento da consciência de si próprio como a força para superar desigualdades. Do modo como o conceito de empoderamento tem sido promovido, nos meios de comunicação, frequentemente ele se resume a um instrumento para fomentar a necessidade das mulheres de garantirem um bom emprego e acumularem bens, para que tenham um futuro "seguro". Entretanto, tal ideologia transfere a responsabilidade da 
condição social e econômica unicamente para o indivíduo, removendo da equação o cenário político e social que, de fato, gerou tal condição, e criando uma ilusão de que a exploração e a discriminação das mulheres estão sendo efetivamente combatidas. Verificamos, portanto, claras distinções entre os dois conceitos e suas aplicações pragmáticas, passando então a apontar aspectos relevantes do processo emancipatório das três personagens principais dos filmes estudados - Val, de Que Horas Ela Volta?, Hermila, de O Céu de Suely, e Rosália, de Pela Janela.

\subsection{A emancipação financeira pelo trabalho}

Se a emancipação como processo libertador pode começar a ser vislumbrada a partir de um empoderamento financeiro, ainda que não exclusivamente por meio dele, é possível verificar nos filmes analisados um aspecto narrativo marcante no que diz respeito à escassez de recursos no retrato do cotidiano dessas mulheres, condição essa que indubitavelmente limita suas escolhas pessoais e profissionais. Analisando a situação econômica das três protagonistas - Val, de Que Horas Ela Volta?, Hermila, de O Céu de Suely, e Rosália, de Pela Janela -, o primeiro fator que se destaca em suas distintas e ao mesmo tempo semelhantes realidades é a simplicidade.

Val é uma empregada doméstica de origem nordestina, um dos cargos mais desprezados da cadeia laboral no país, remetendo à época (não tão distante) em que a escravidão era uma condição aceitável para uma parcela da população brasileira. Apesar dos incansáveis anos de serviço, ela mora no "quarto de empregada" da mansão dos patrões, em uma área pequena e sem ventilação, afastada dos ambientes sociais da casa. Hermila, jovem também nordestina, mãe solteira e sem profissão definida, encontra-se abandonada pelo "marido" e retorna à sua cidade natal, a pequena Iguatu, no interior do Ceará, para morar de 
favor na casa de familiares. Em um contexto de pobreza e falta de oportunidades, passa a realizar pequenos trabalhos informais, como vender rifas e lavar carros. Já Rosália, trabalhadora braçal de uma fábrica, possivelmente aguardando a aposentadoria, vive na periferia de uma metrópole, dividindo uma pequena casa com o irmão. Sua situação financeira, longe de confortável, torna-se ainda mais crítica quando ela é demitida do emprego que ocupava há 30 anos na empresa, sem motivo aparente além de uma reorganização interna da nova diretoria. Embora Val tenha um emprego fixo e Hermila alguns trabalhos temporários, enquanto Rosália se encontra desempregada, as três vivenciam situações de poucas perspectivas no que diz respeito a crescimento profissional.

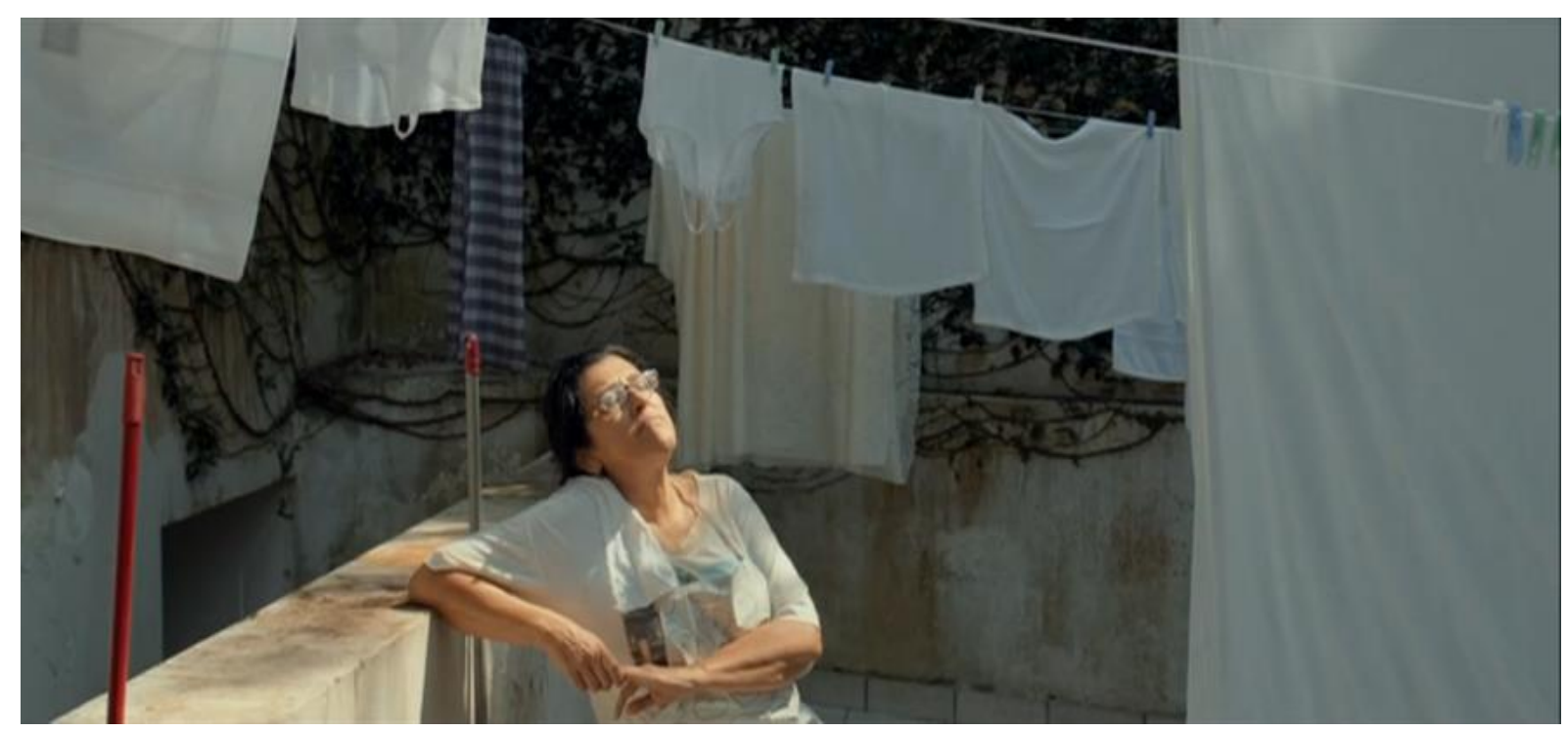

Imagem 1: Val, de Que Horas Ela Volta? (Anna Muylaert, 2015), é uma empregada doméstica que mora no "quartinho de serviço"da casa dos patrões. () Globo Filmes, Gullane Filmes, África Filmes, Pandora Filmes. 


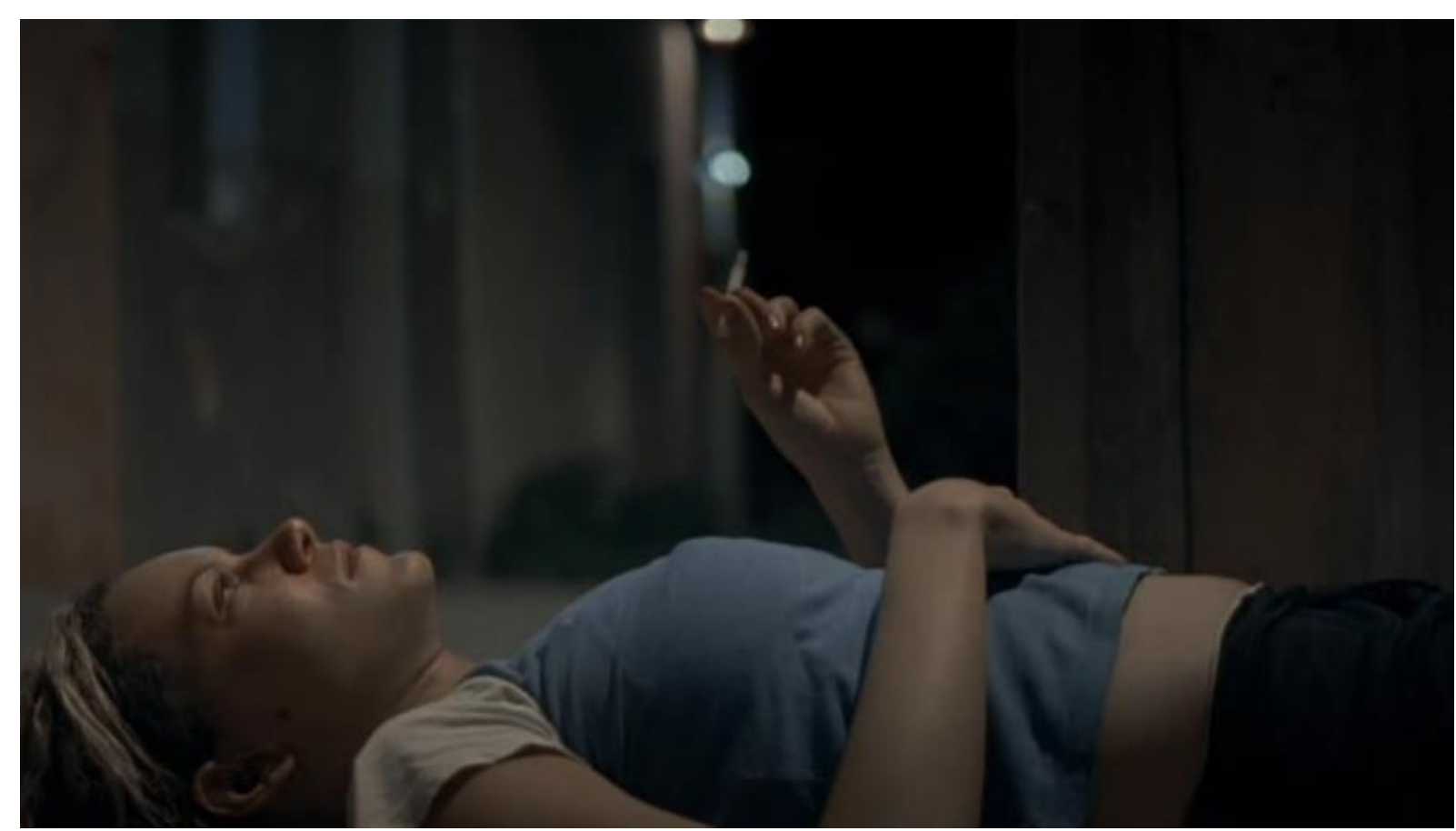

Imagem 2: Hermila, de $O$ Céu de Suely (Karim Aïnouz, 2006), volta da cidade grande para sua terra natal e se hospeda na casa da avó. (C) VideoFilmes, Celluloid Dreams, Shotgun Pictures.

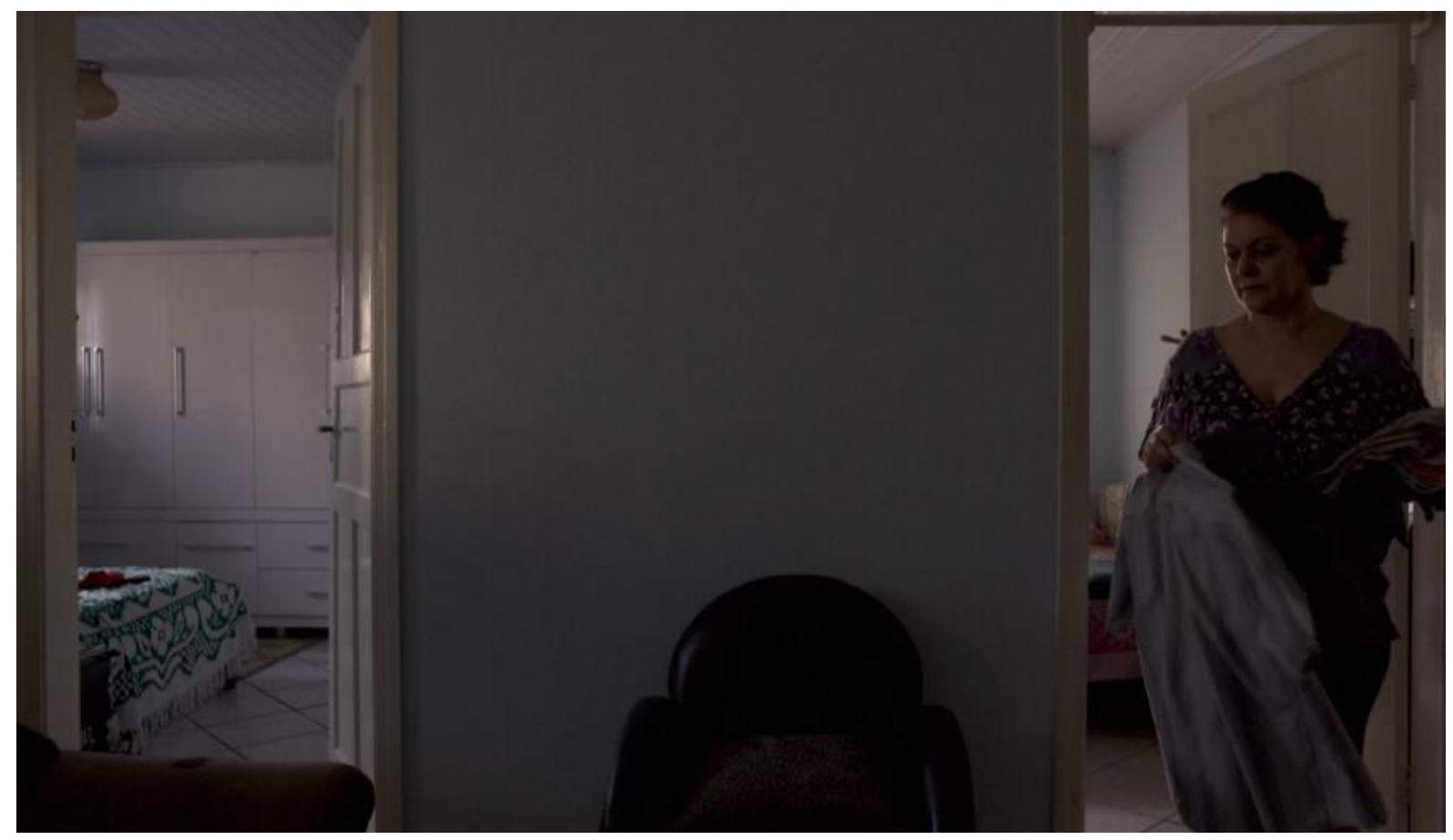

Imagem 3: Rosália, de Pela Janela (Caroline Leone, 2017), divide uma casa humilde, na periferia de São Paulo, com seu irmão. (C) Vitrine Filmes.

Não é coincidência o fato de as protagonistas dos três filmes estudados serem pessoas de origens humildes, sem muito acesso à educação formal. Embora não seja o único elemento 
a ser considerado nesta análise, a influência da escolaridade na distribuição de renda do país é notadamente um aspecto relevante quando se trata de empoderamento e emancipação. A ideia de que a educação produz riqueza se fundamenta na Teoria do Capital Humano, segundo a qual a educação traz como efeito a aquisição de conhecimentos e o desenvolvimento de habilidades, tornando os indivíduos mais produtivos e gerando riquezas; por consequência, influenciado positivamente as taxas de crescimento dos países (SCHULTZ, 1963).

O grau de escolaridade define, no Brasil, muito mais do que as habilidades profissionais de um indivíduo. É um aspecto que nivela a população de acordo com seu status social. Até mesmo Fabinho, o filho da patroa, que demonstra clara afeição por Val, em Que Horas Ela Volta?, observa o sotaque da empregada e de sua filha como uma característica de diferenciação das classes. De um lado, encontra-se o proletariado, sem acesso a boas escolas, cursos de idiomas ou viagens ao exterior. De outro, está a classe privilegiada, que se surpreende ao perceber que Jéssica tem a intenção de prestar vestibular na mesma universidade que Fabinho, acreditando ter as mesmas chances que ele. Esse gesto, de se inscrever em um curso reservado a priori para uma elite, é mais um dos motivos pelos quais a jovem está tão à frente das outras personagens no processo emancipatório, até mesmo quando comparada à sua própria mãe. Jéssica compreendeu o valor da educação para abrir portas, munindo-a de ferramentas que lhe permitam exercer uma profissão na qual seja respeitada como igual, em uma área de atuação que proporcione ascensão econômica.

Para Val, não se trata apenas do que ela considera inferioridade intelectual. Trata-se de não ultrapassar uma barreira imaginária, separando-a de um grupo social ao qual jamais irá pertencer. Seu papel é servir água, mesmo quando a pessoa servida é completamente capaz de pegar um copo. É sua função também levar à mesa dos patrões o sorvete caro e exclusivo, reservado apenas para quem tem direito a ele. É dormir no quartinho pouco arejado, enquanto diversas suítes permanecem vazias na casa. Seu trabalho é circular pelas áreas sociais somente 
quando sua presença for solicitada e se restringir à cozinha ou à área de serviço. E, naturalmente, sequer pensar em entrar na piscina.

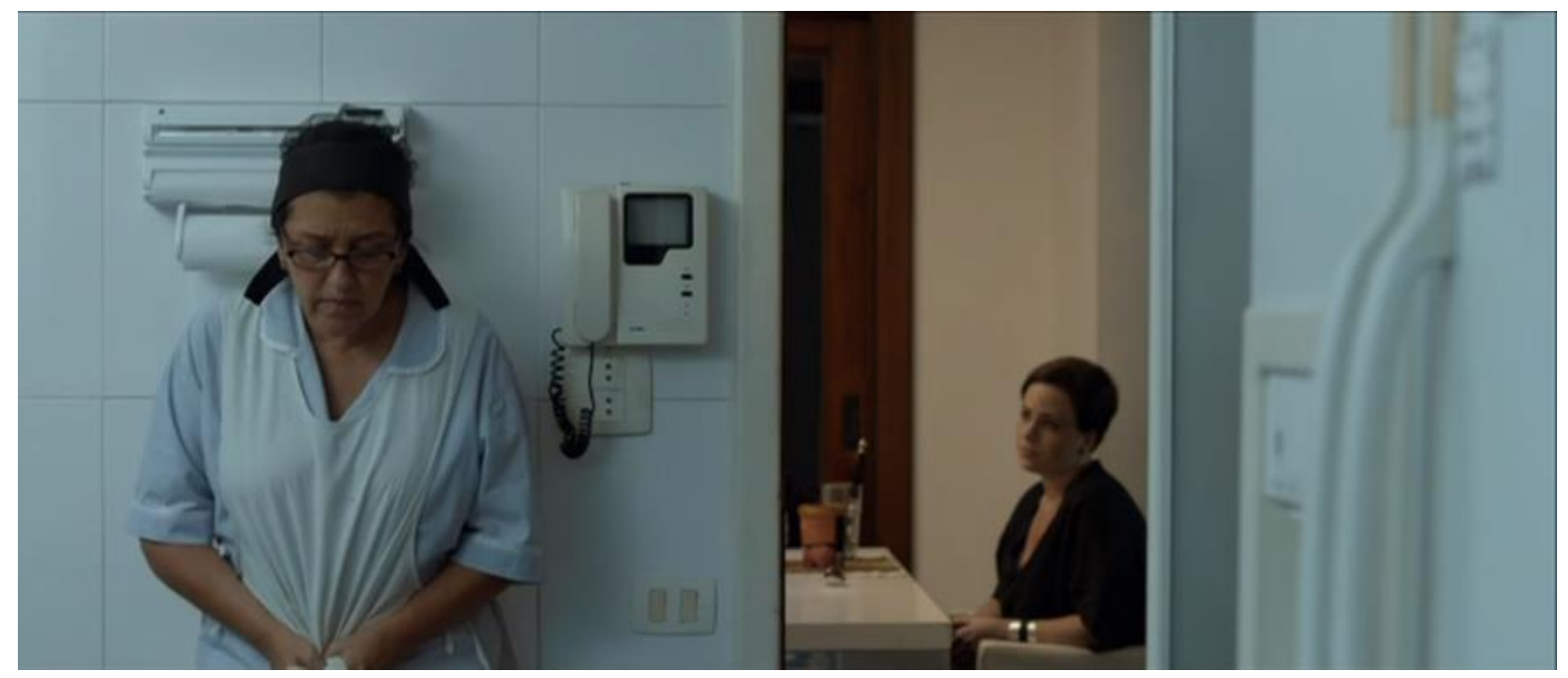

Imagem 4: Cena de Que Horas Ela Volta? (Anna Muylaert, 2015): há uma divisão territorial clara entre patrões e empregados. () Globo Filmes, Gullane Filmes, África Filmes, Pandora Filmes.

Quando a filha passa a questionar essas imposições - falando com os patrões de igual para igual, sentando-se à mesa deles, tomando para si o quarto de hóspedes, comendo o sorvete "especial" e aproveitando a piscina sem culpa alguma -, Val se mostra visivelmente constrangida e até mesmo chocada com esse comportamento, encaixando-se no estereótipo de que as mulheres devem constantemente se desculpar, em especial quando agem de maneira considerada atípica ou inapropriada. Embora estudos de psicologia demonstrem que pessoas do gênero feminino, de fato, tendem a pedir desculpas com mais frequência do que os homens, devido à sua diferente percepção no que diz respeito a comportamentos ofensivos (SCHUMMAN; ROSS, 2010), o condicionamento social de que a mulher deve ocupar uma posição submissa corrobora esse tipo de atitude. 


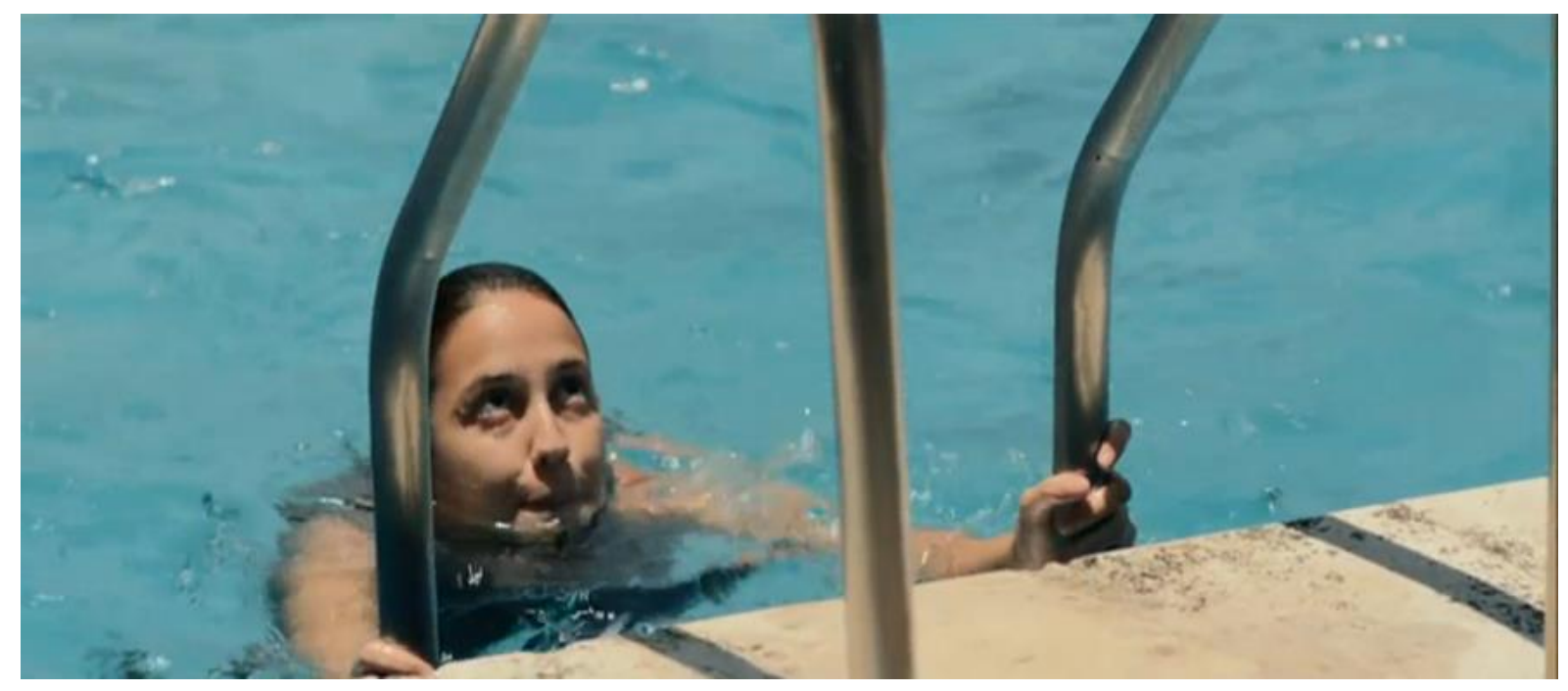

Imagem 5: Com uma postura propositalmente desafiadora, Jéssica não se importa com as proibições no que diz respeito a usar a piscina dos patrões, em Que Horas Ela Volta? (Anna Muylaert, 2015). (C Globo Filmes, Gullane Filmes, África Filmes, Pandora Filmes.

O momento chave que motiva Val a deixar de justificar as atitudes da patroa e considerar as necessidades da filha pode ser percebido na cena em que Jéssica é flagrada comendo sorvete escondido. Logo em seguida, a patroa encontra uma bandeja quebrada e chama a empregada para conversar, em tom de ameaça. De maneira categórica e beirando a rudeza, deixando absolutamente claro que está contando as horas para a partida de Jéssica, Bárbara pede a Val para "deixar ela [no caso, referindo-se à jovem transgressora] da porta da cozinha para lá".

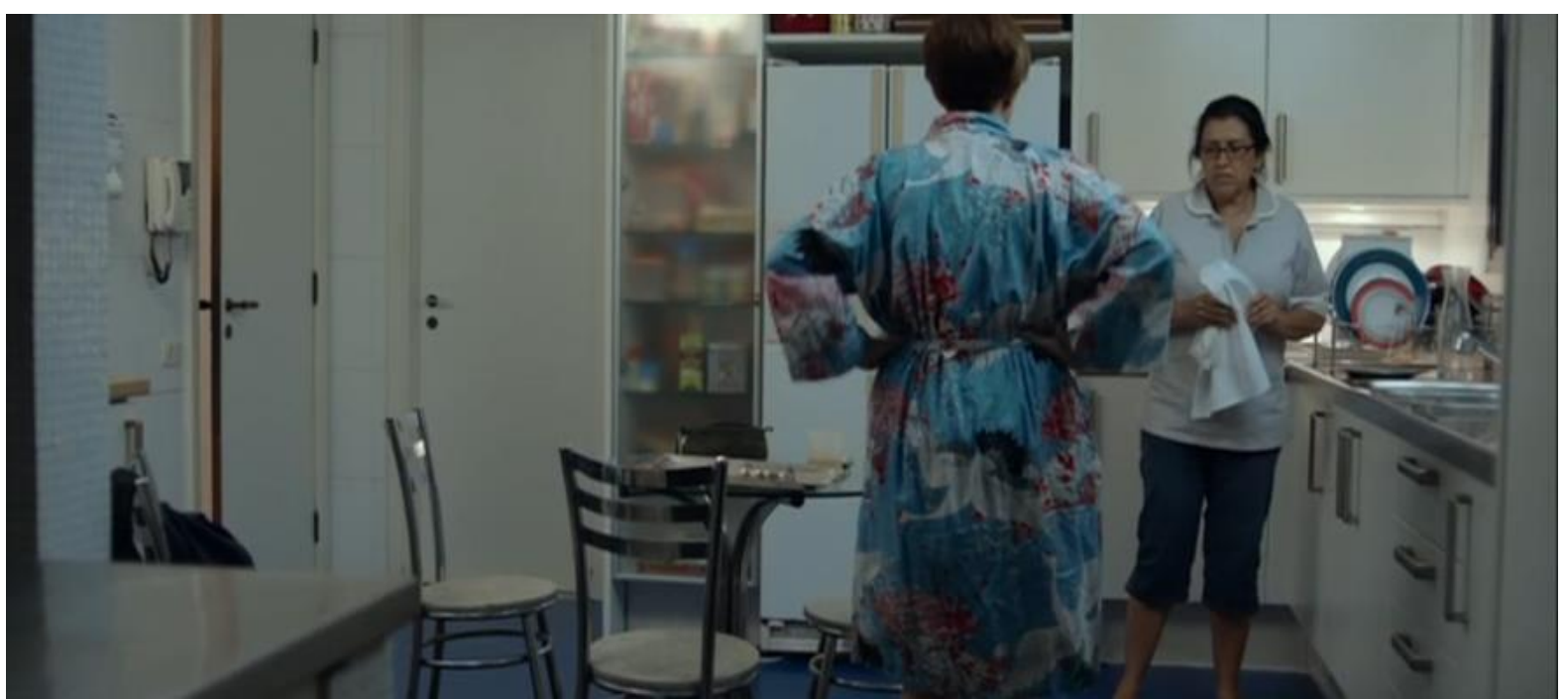

Imagem 6: A patroa confronta Val e pede que a circulação de Jéssica na casa se limite à cozinha, em Que Horas Ela Volta? (Anna Muylaert, 2015). (C) Globo Filmes, Gullane Filmes, África Filmes, Pandora Filmes. 
O resultado dessa interação é que a moça faz as malas e vai embora, debaixo de chuva, na noite de véspera à prova do vestibular. Ainda assim, ela é aprovada (ao contrário de Fabinho) e Val celebra da maneira mais libertária possível: entrando na piscina "proibida". Outros fatos vão se acumulando, ao longo da história, para que a empregada comece a "soltar as amarras" que a prendem à casa: ela finalmente consegue alugar um apartamento para dividir com sua filha e descobre que tem um neto; além disso, Fabinho parte para um intercâmbio fora do país. O pedido de demissão, uma consequência desse processo emancipatório, é recebido com surpresa pela patroa, mas representa algo que ela precisava fazer há muitos anos: "ficar com minha filha, cuidar de minha filha."

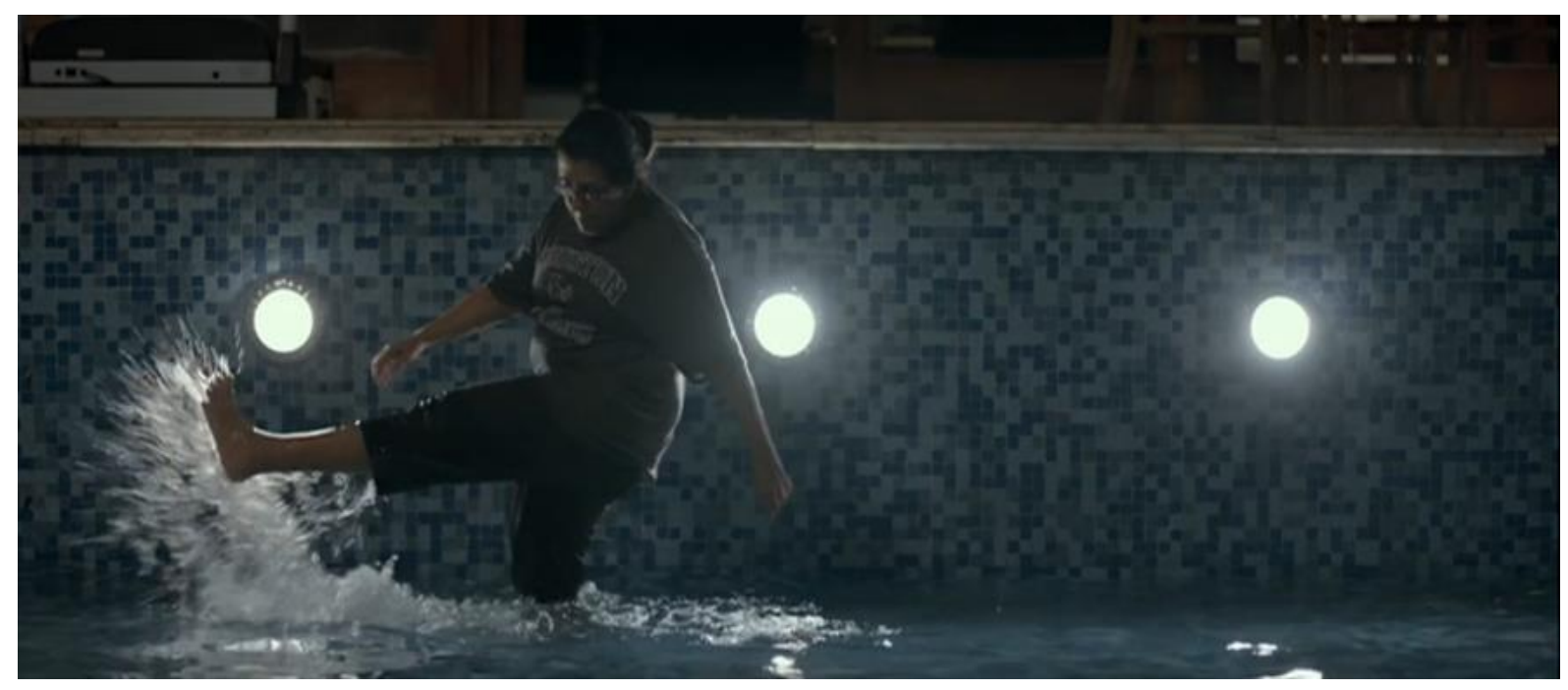

Imagem 7: Gesto desafiador: Val brinca na piscina, em Que Horas Ela Volta? (Anna Muylaert, 2015). @ Globo Filmes, Gullane Filmes, África Filmes, Pandora Filmes.

O gradiente apresentado na luta pela emancipação de Val situa uma contradição com relação ao empoderamento. Ela não é seduzida pela possibilidade de se libertar dos patrões; pelo contrário, sua índole a encaminha para percepções mais profundas e consequentes das nuances de sua situação empregatícia. A tomada de decisão que parte dessa conscientização 
não beneficia somente a ela, mas a todo o seu entorno (filha e neto, primordialmente), mostrando a emancipação da personagem no âmbito coletivo.

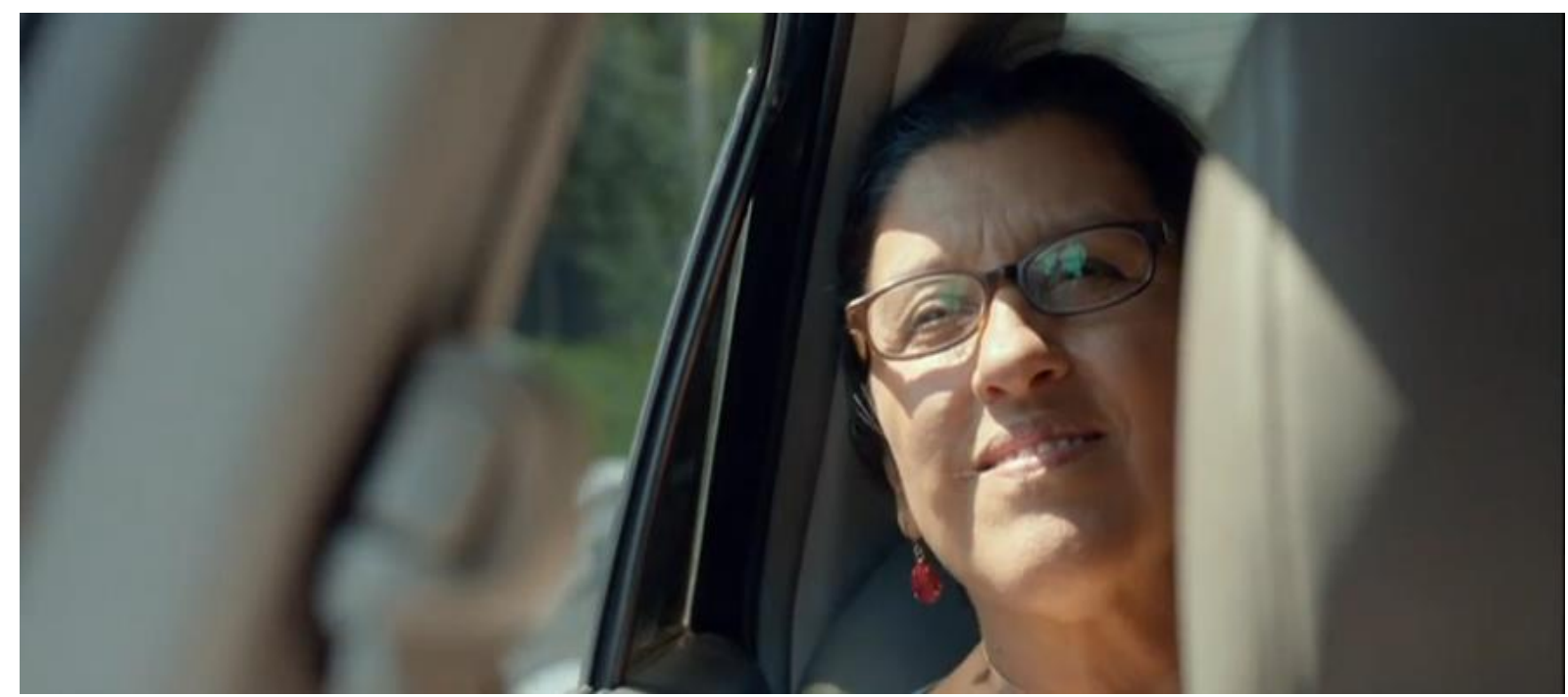

Imagem 8: Com o pedido de demissão, Val dá um grande passo em seu processo emancipatório, em Que Horas Ela Volta? (Anna Muylaert, 2015). @ Globo Filmes, Gullane Filmes, África Filmes, Pandora Filmes.

No caso de Hermila, em $O$ Céu de Suely, a insatisfação com sua posição social e as dificuldades financeiras, exacerbadas pelo abandono de Matheus (interpretado por Matheus Vieira), o pai de seu filho, são fatores de ruptura. Porém, ao invés de levarem a personagem a buscar formas possíveis de emancipação, esses elementos a colocam em uma prisão de frustrações. Afinal, Matheus mandou dinheiro para a mãe dele dar entrada em uma geladeira, mas não hesitou em deixar a mulher e o filho absolutamente desamparados. "E a senhora acha justo eu cuidar desse menino sozinha?", questiona ela, para a mãe do rapaz.

Uma jovem inexperiente, sem estudo ou formação profissional, em uma cidade sem grandes perspectivas, Hermila precisa fazer o possível para sobreviver nas circunstâncias em que se encontra, cuidando de si mesma e de Matheuzinho, além de ajudar a avó nas contas da casa. Precisa ainda aceitar que os planos de montar um negócio com o ex-marido, que envolviam a compra de uma copiadora de CDs, simplesmente não irão se realizar. A 
alternativa, portanto, é trabalhar na informalidade, fazendo pequenos "bicos", como vender rifas na rua e lavar carros em um posto de gasolina.

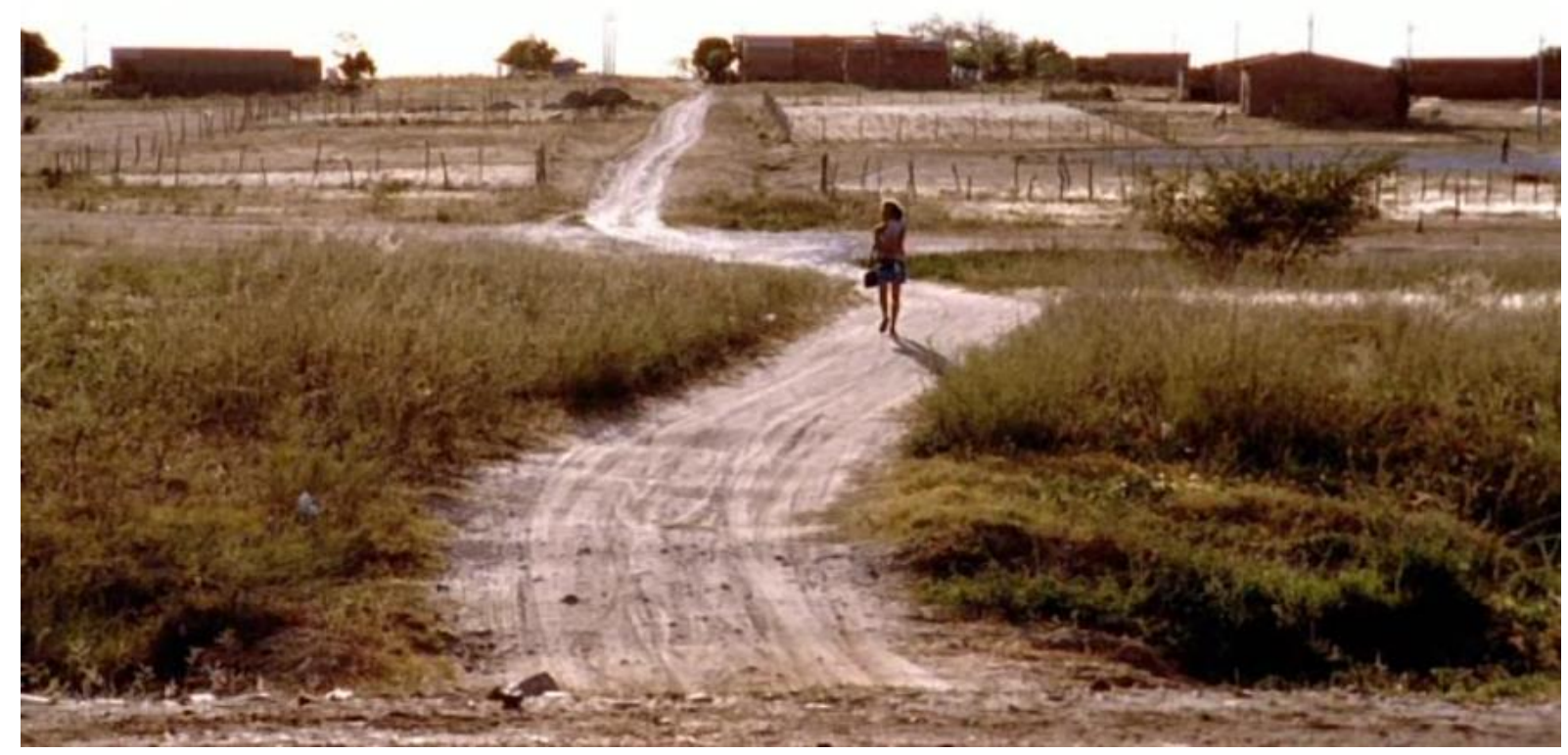

Imagem 9: Hermila é abandonada em Iguatu pelo pai de seu filho e precisa cuidar do menino sozinha, em $O$ Céu de Suely (Karim Aïnouz, 2006). (C) VideoFilmes, Celluloid Dreams, Shotgun Pictures.

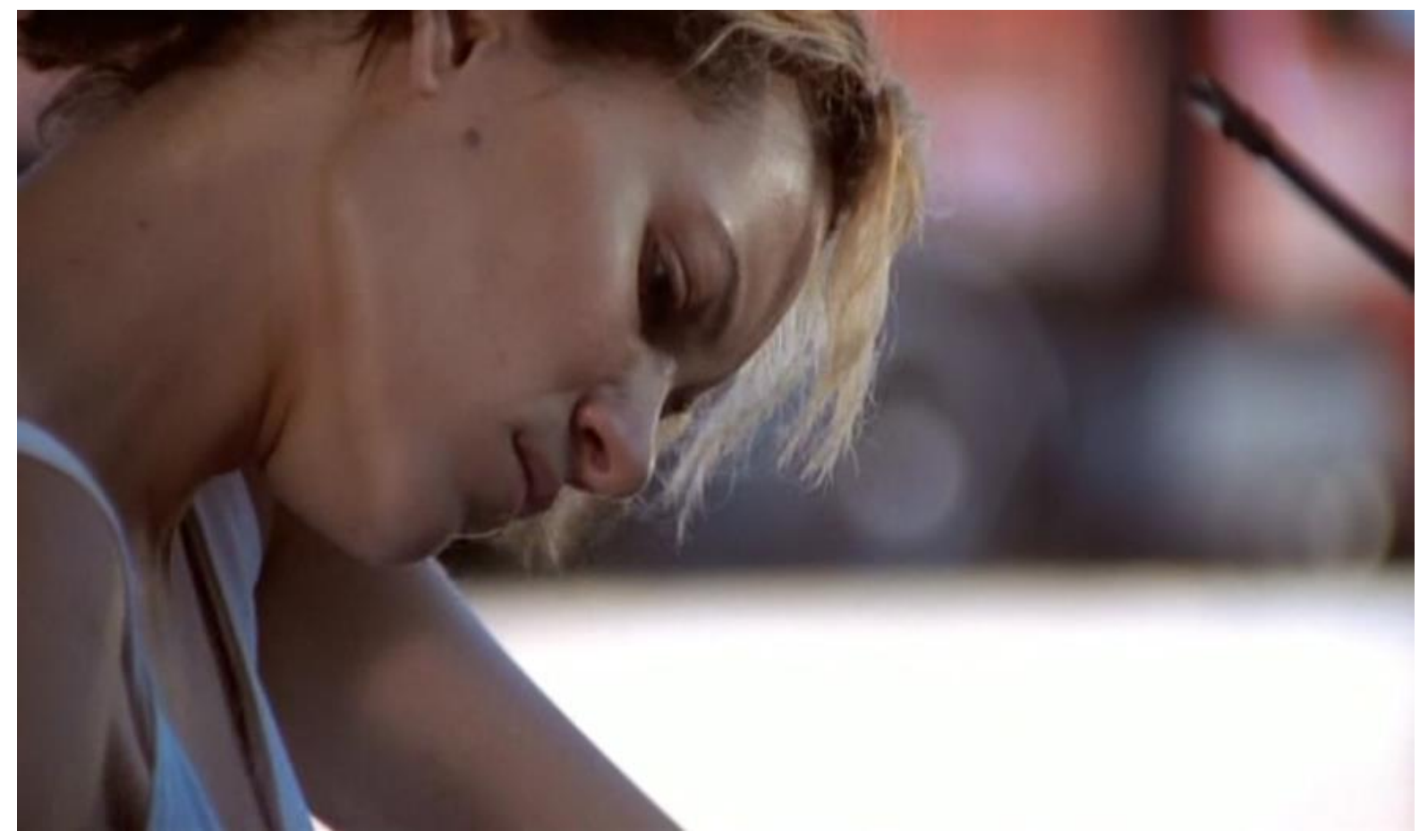

Imagem 10: Sem formação profissional, Hermila ganha a vida com trabalhos informais e pouco valorizados, em O Céu de Suely (Karim Aïnouz, 2006). @ VideoFilmes, Celluloid Dreams, Shotgun Pictures. 
Em uma sociedade na qual o valor do ser humano é definido por seu trabalho, a mulher que se submete a subempregos para sustentar sozinha um filho abandonado pelo pai se encontra na base da cadeia de valores. Mesmo nessas condições, o desejo de escapar da realidade que a oprime existe e se mostra latente em Hermila. O primeiro indício dessa insatisfação se mostra quando a jovem se encaminha até a rodoviária da cidade e pergunta qual a passagem disponível para o local mais distante de Iguatu. Este se torna seu objetivo imediato: conseguir dinheiro para ir embora, para o lugar mais longe possível.

Um vislumbre de solução para seus problemas financeiros surge em uma conversa entre Hermila e sua amiga Georgina (Georgina Castro), uma garota de programa que atende pelo nome de Jéssica. A moça pergunta quanto a amiga ganha para realizar esse trabalho, plantando a semente do plano que irá florescer algum tempo depois: o de vender seu corpo em uma rifa, "uma noite no paraíso". O objetivo inicial seria "ficar rica", como ela mesma afirma, em uma discussão com sua tia; Hermila chega a acreditar que poderá comprar uma casa para ela e o filho, com esse dinheiro. Eventualmente, percebe que as expectativas precisam se ajustar à realidade, já que conseguiria no máximo arrecadar o valor de uma passagem para o sul do país, com a rifa em questão.

Nesse ponto da história, é evidente que, ao vivenciar uma situação de ruptura, Hermila não se encaminhou para a emancipação, mas se tornou ainda mais alienada em seus desejos de fuga. A ansiedade juvenil por escapar de um universo considerado por ela como opressivo e árido leva a personagem a se colocar "à venda", conformando-se à posição de objeto e se afastando cada vez mais da possibilidade de se tornar sujeito ativo na própria história. Talvez Hermila conquiste o empoderamento que o mundo da economia sexual pode lhe oferecer, se ela fizer as escolhas adequadas para isso. Porém, a emancipação real - representada pela autonomia de escolher seu destino e não depender de terceiros - parece mais e mais distante para ela. 


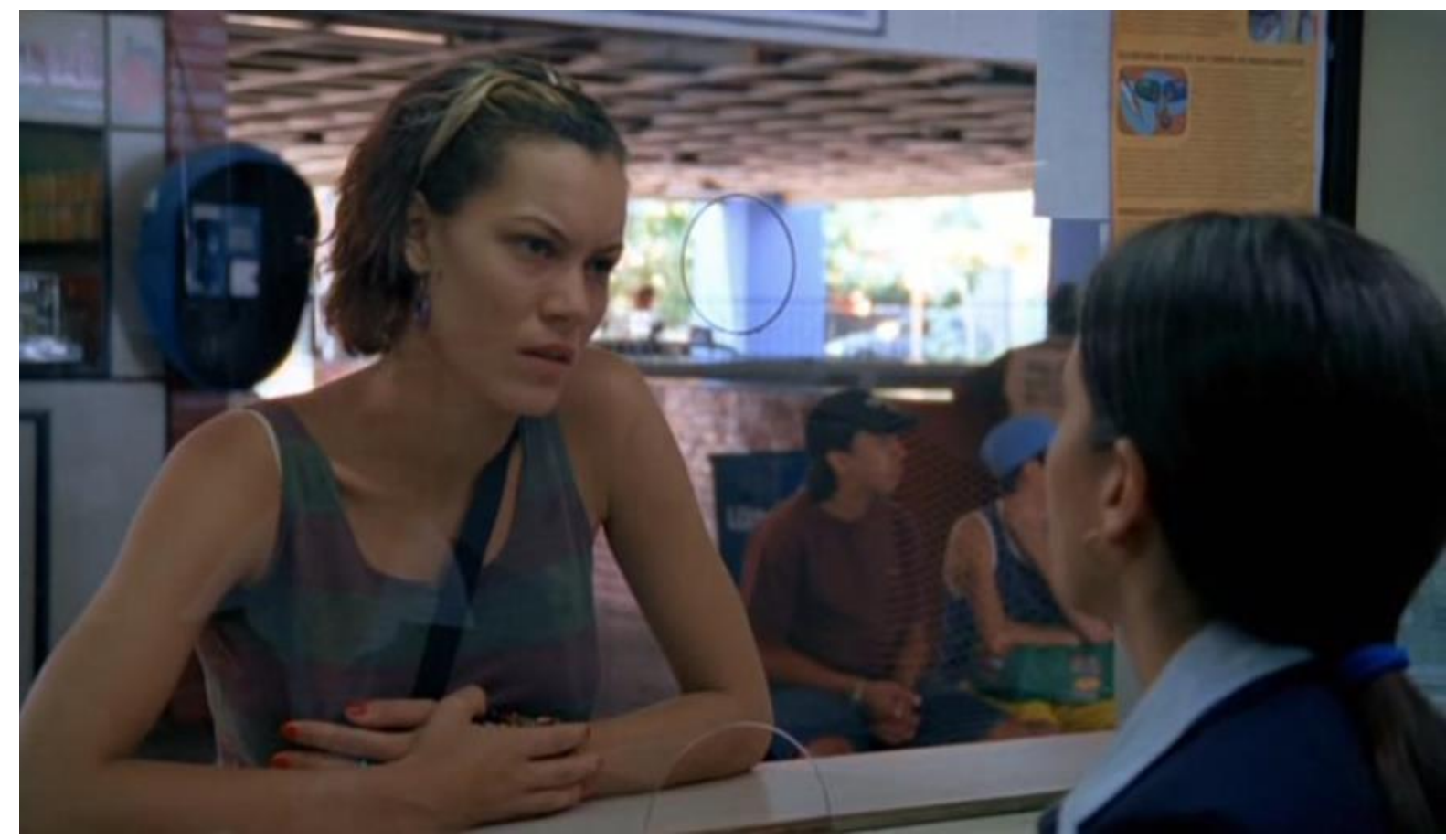

Imagem 11: Mesmo sem dinheiro para viajar, Hermila pergunta quanto custa a passagem para o local mais distante de Iguatu, em $O$ Céu de Suely (Karim Aïnouz, 2006). @ VideoFilmes, Celluloid Dreams, Shotgun Pictures.

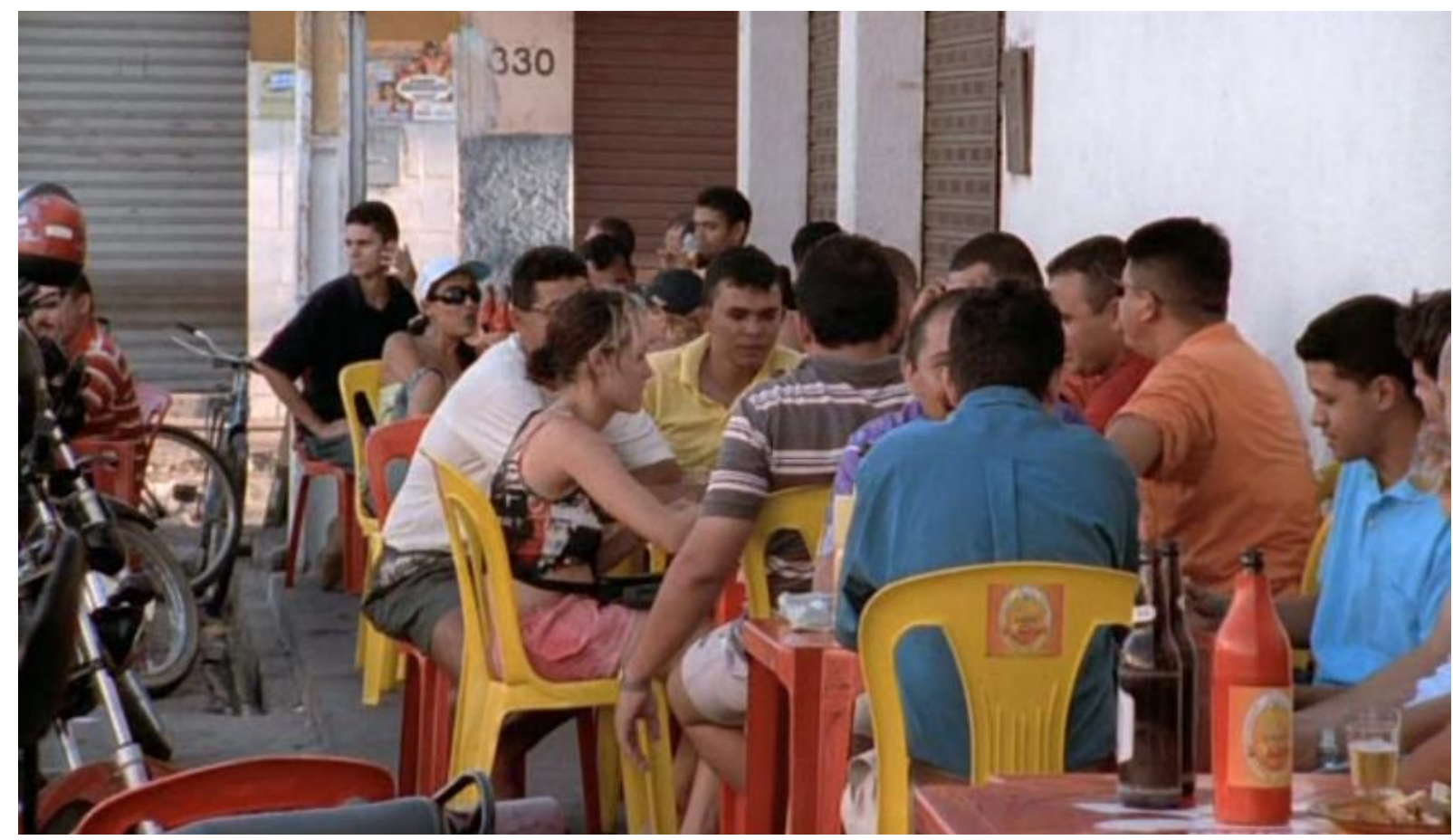

Imagem 12: Hermila vende uma rifa de seu corpo, posicionando-se em sua própria história como objeto, ao invés de sujeito, em $O$ Céu de Suely (Karim Aïnouz, 2006). (C) VideoFilmes, Celluloid Dreams, Shotgun Pictures.

Em comparação, é importante observar que, embora Val tenha uma condição financeira melhor do que a de Hermila, que lhe possibilita escolhas (como se demitir e traçar 
planos de se tornar massagista), ela também é obrigada a tomar decisões que a desagradam, devido à falta de dinheiro. Por exemplo, quando Val e a filha estão preparadas para a mudança da casa dos patrões para seu próprio apartamento e descobrem que não poderão entrar no imóvel imediatamente, por não terem realizado um depósito, o retorno à situação de constrangimento e dependência de favores alheios deixa Jéssica extremamente insatisfeita. Contudo, mãe e filha se sujeitam a esse período de provação porque têm consciência da liberdade que irão conquistar em breve e do que isso representa em suas vidas.

Embora Hermila se esforce, à sua maneira, para conquistar a independência financeira, a suposta solução encontrada para "cortar caminhos" acaba se tornando mais um problema em sua vida. Ela é confrontada pela família, por desconhecidos e até mesmo por clientes em potencial, a respeito dessa decisão; contudo, mantém-se firme na meta de obter muito dinheiro rapidamente. Em sua impaciência, a personagem não está disposta a esperar para concretizar seus sonhos, ou enfrentar o longo e árduo caminho de descobrir seu papel no mundo como ser humano emancipado.

\begin{abstract}
"Parte da jornada da heroína é encontrar sua tarefa no mundo, o que permite que ela encontre sua identidade. É importante para uma mulher saber que ela pode sobreviver sem depender dos pais ou de outrem, para que possa expressar as vontades de seu coração, mente e alma. As habilidades aprendidas durante a primeira parte da jornada heroica estabelecem a competência da mulher no mundo." (MURDOCK, 1990, p. 44)
\end{abstract}

É compreensível, no entanto, que Hermila desconheça seu próprio valor. A constante desvalorização das mulheres em um âmbito externo afeta a percepção delas sobre si mesmas, internamente, além de influenciar a maneira como veem sua condição feminina no mundo (MURDOCK, 1990). A mulher precisa lutar constantemente por si mesma, desde muito cedo, porque é reforçado pela família e pela sociedade que os interesses de todas as outras pessoas precisam ser consideradas antes dos dela própria. Naturalmente, nesse contexto, as escolhas de Hermila seriam julgadas como impensadas ou errôneas pelos outros. A jovem é percebida 
como egoísta por usar seus atributos físicos para obter sua passagem de saída de Iguatu, deixando o filho (uma responsabilidade sua) com a avó. Ao mesmo tempo em que tenta confrontar um sistema que insiste em dizer como ela deve ou não agir, ela busca se encontrar, perdendo-se ainda mais.

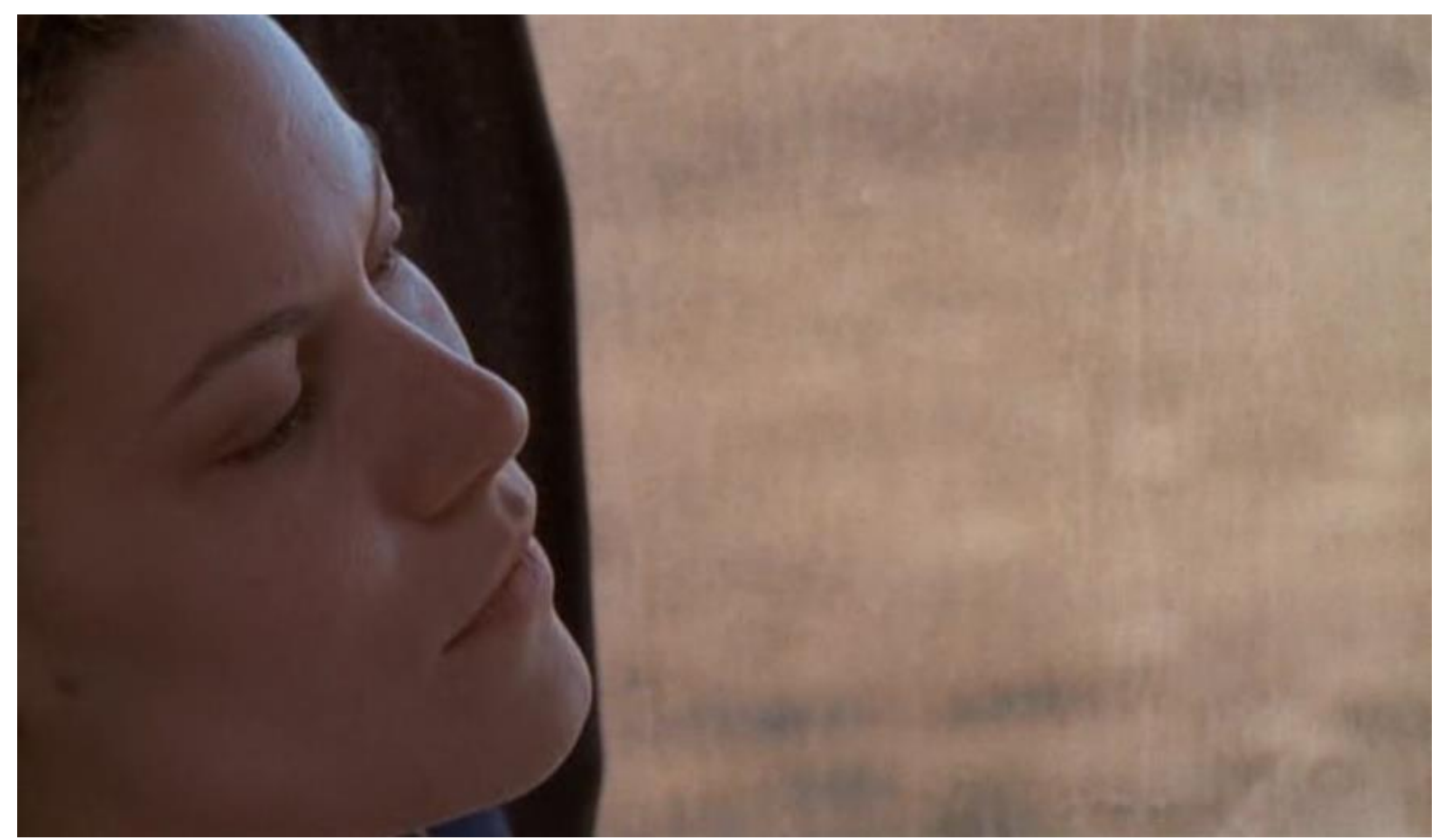

Imagem 13: Com a rifa, Hermila obtém o dinheiro para sair de Iguatu, mas não alcança a emancipação, em $O$ Céu de Suely (Karim Aïnouz, 2006). (C) VideoFilmes, Celluloid Dreams, Shotgun Pictures.

Assim como Hermila, a personagem Rosália, de Pela Janela, parece fadada à alienação, tanto do empoderamento quanto da emancipação. Ela cumpre seu dever, vivendo em função do trabalho em uma fábrica de reatores (âmbito profissional), ou cuidando da casa e do irmão (âmbito pessoal). Sacrificou seu tempo, sua energia e seus relacionamentos - com os outros e consigo mesma - para ser uma operária, aparentemente incansável, sempre a serviço de outrem. Ao invés de uma jornada heroica, optou por uma jornada estoica, em um mundo ditado por modelos de conduta masculinos.

A ruptura, para Rosália, acontece quando a personagem se dá conta de que, na máquina capitalista da qual faz parte, ela é simplesmente mais uma peça da engrenagem, 
facilmente substituível. Afinal, sem a operária, a máquina pode continuar funcionando perfeitamente. Nessa equação, a única parte que sai prejudicada é ela mesma: mulher madura, desvalorizada por uma sociedade que glorifica a juventude, descartada sem perspectivas ou alternativas para o futuro. Para alguém que buscava seu valor no reconhecimento alheio, esse tipo de ruptura é recebido como o "fim da linha".

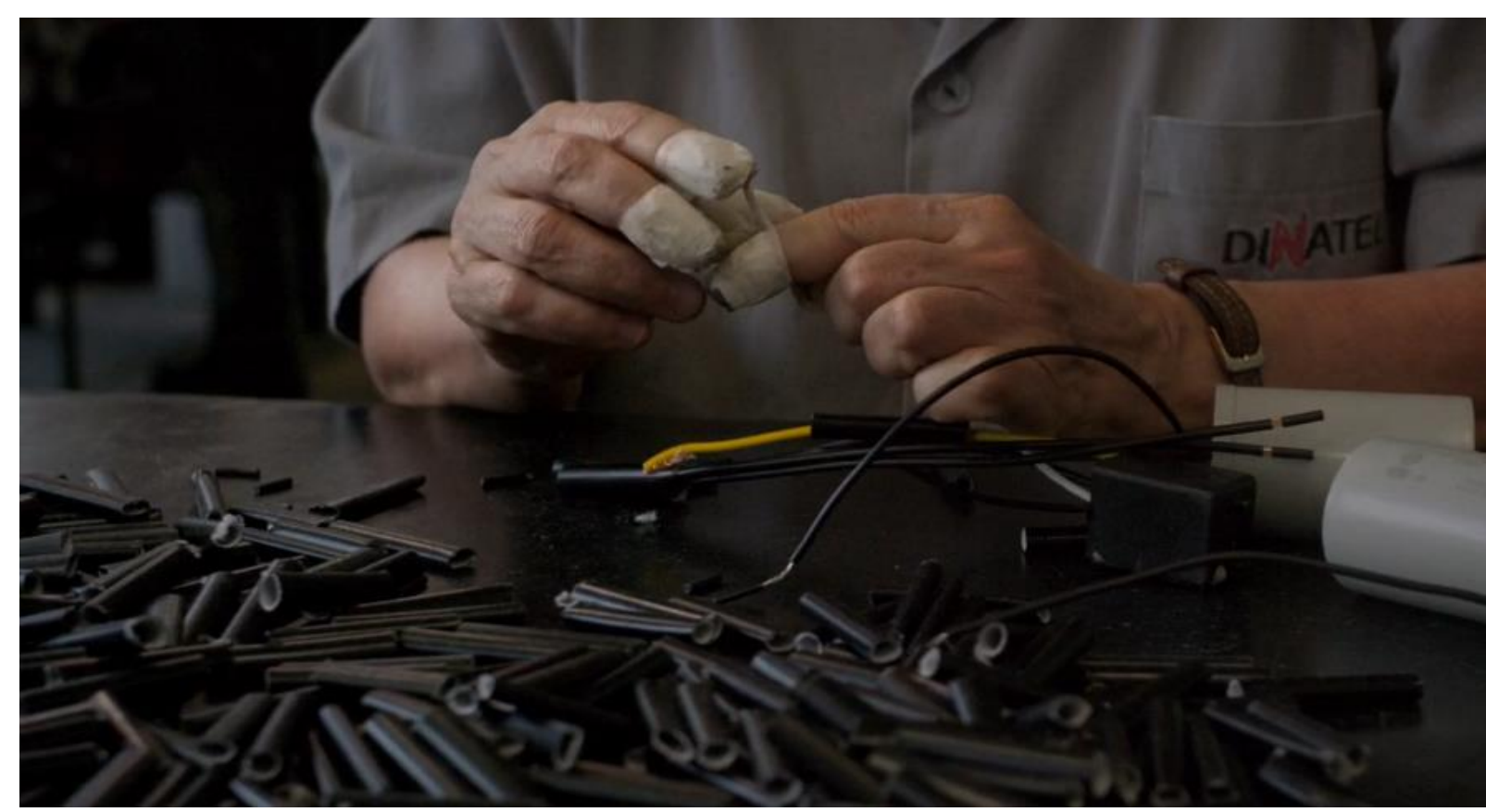

Imagem 14: Na máquina capitalista, Rosália é apenas mais uma peça da engrenagem, em Pela Janela (Caroline Leone, 2017). (C) Vitrine Filmes.

A constante busca por validação e aprovação dos outros é uma característica presente em muitas mulheres, já que na estrutura patriarcal elas geralmente não são ensinadas a serem independentes e buscarem em si mesmas o sentido de suas vidas. "As meninas são encorajadas a manterem suas relações de dependência com os pais e a família, para depois do casamento as transferirem para o marido e os filhos." (MACKAY, 1983). Basta observar o mercado de trabalho, que, até poucas décadas atrás, era definido e gerido majoritariamente por homens. Conforme aponta Maureen Murdock:

"Embora as mulheres tenham conquistado enormes avanços, e certamente nem todos os homens estão em posição de dominação, a verdade é que elas têm seguido um modus operandi masculino, na maior parte das situações de trabalho - 
mesmo quando em posições de liderança. Trabalhar muitas horas, com foco nos lucros a despeito das relações pessoais, é a regra, não a exceção. Quando uma mulher começa a alimentar um senso de questionamento sobre 'qual o propósito de tudo isso?', o ideal é que ela não mencione isso a seu chefe ou colegas." (MURDOCK, 1990, p. 80)

Rosália, a operária "perfeita", em momento algum do filme se pronuncia para questionar ou contestar o trabalho. Se ela possui insatisfações, não são manifestadas. Ao ser demitida, após 30 anos de serviços prestados com lealdade e eficiência, sua única reação é aceitar a notícia em silêncio e resignação; inclusive retornando, no dia seguinte, prestativa e simpática, para oferecer ajuda ao funcionário que a substituiu - apenas para ser novamente desprezada, como se nada valesse.

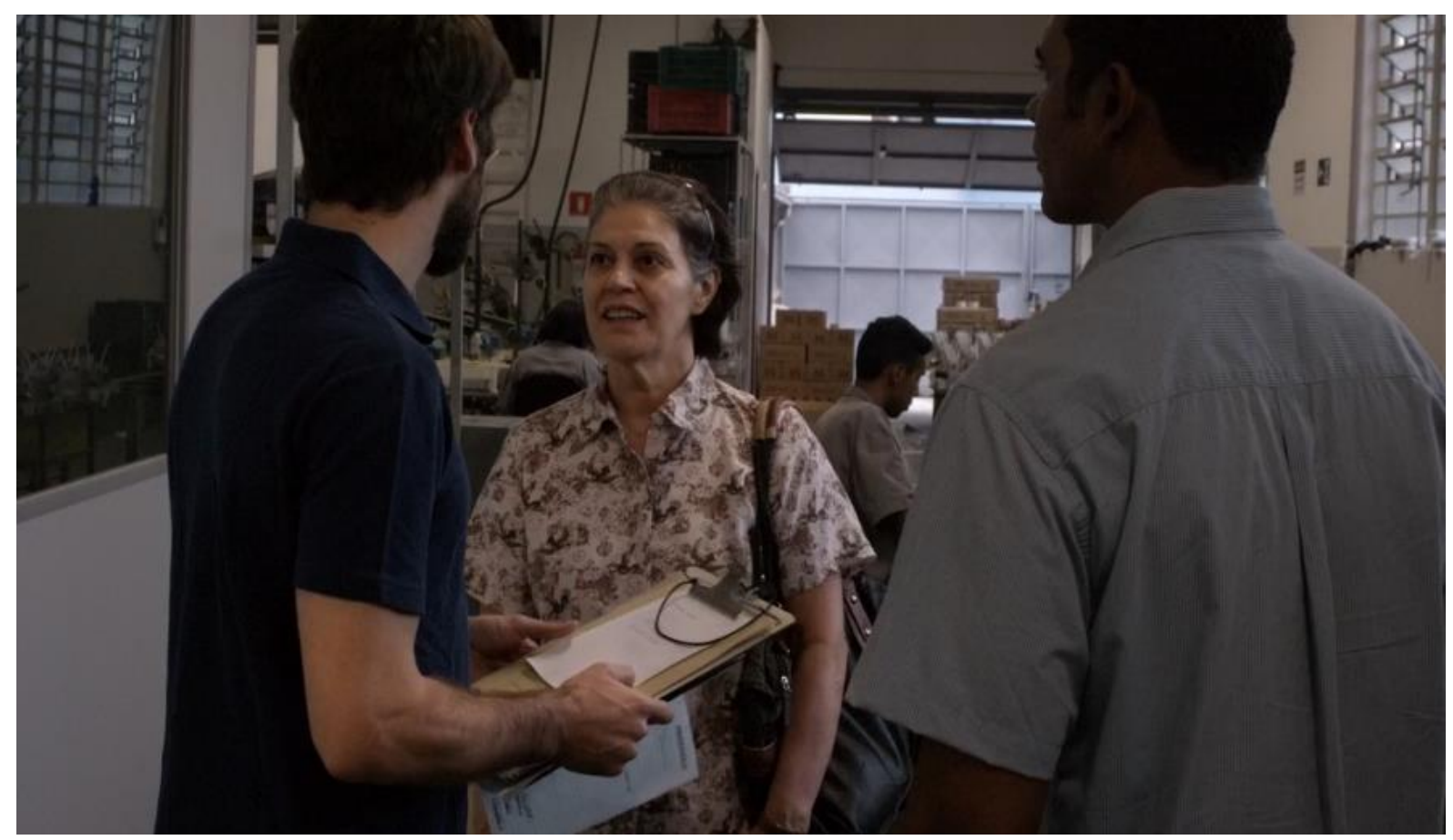

Imagem 15: Mesmo demitida, Rosália retorna à fábrica para oferecer seus serviços, em Pela Janela (Caroline Leone, 2017). ( ) Vitrine Filmes.

No poema $O$ Mito da Inferioridade Feminina, Erica Jong resume de forma eloquente esse sentimento de inadequação e de constante busca por validação da mulher, em um universo profissional determinado por regras masculinas: "O melhor escravo não precisa ser chicoteado. Ele chicoteia a si mesmo." (JONG; apud MURDOCK, 1990). O mito de nunca ser 
suficiente é intrínseco ao modo de produção capitalista; afinal, se existe a necessidade de aprovação alheia, pela conquista de resultados ou bens de consumo, existe a garantia de uma força trabalhadora.

No caso específico da mulher, dizer "não" a uma tarefa é algo impensável. Qualquer atitude insubmissa gera surpresa e mal-estar, pois é esperado dela que sempre se submeta. Conforme atesta Murdock, por experiência própria, a possibilidade de se negar a realizar um trabalho representa um sentimento dúbio, para a mulher:

"Uma sensação tanto de luto quanto de libertação. Eu lamentava não me encaixar, não ser produtiva como o esperado, não fazer parte da comunidade que amava. Mas também celebrava minha recém-descoberta liberdade e a consciência de ter sido verdadeira com minha jornada interna." (MURDOCK, 1990, p. 83)

No que diz respeito à reação de Rosália à demissão, a jornada emancipatória sequer é vislumbrada no momento da ruptura, porque ela se fecha no luto e deixa de perceber a oportunidade de libertação que reside nesse acontecimento.

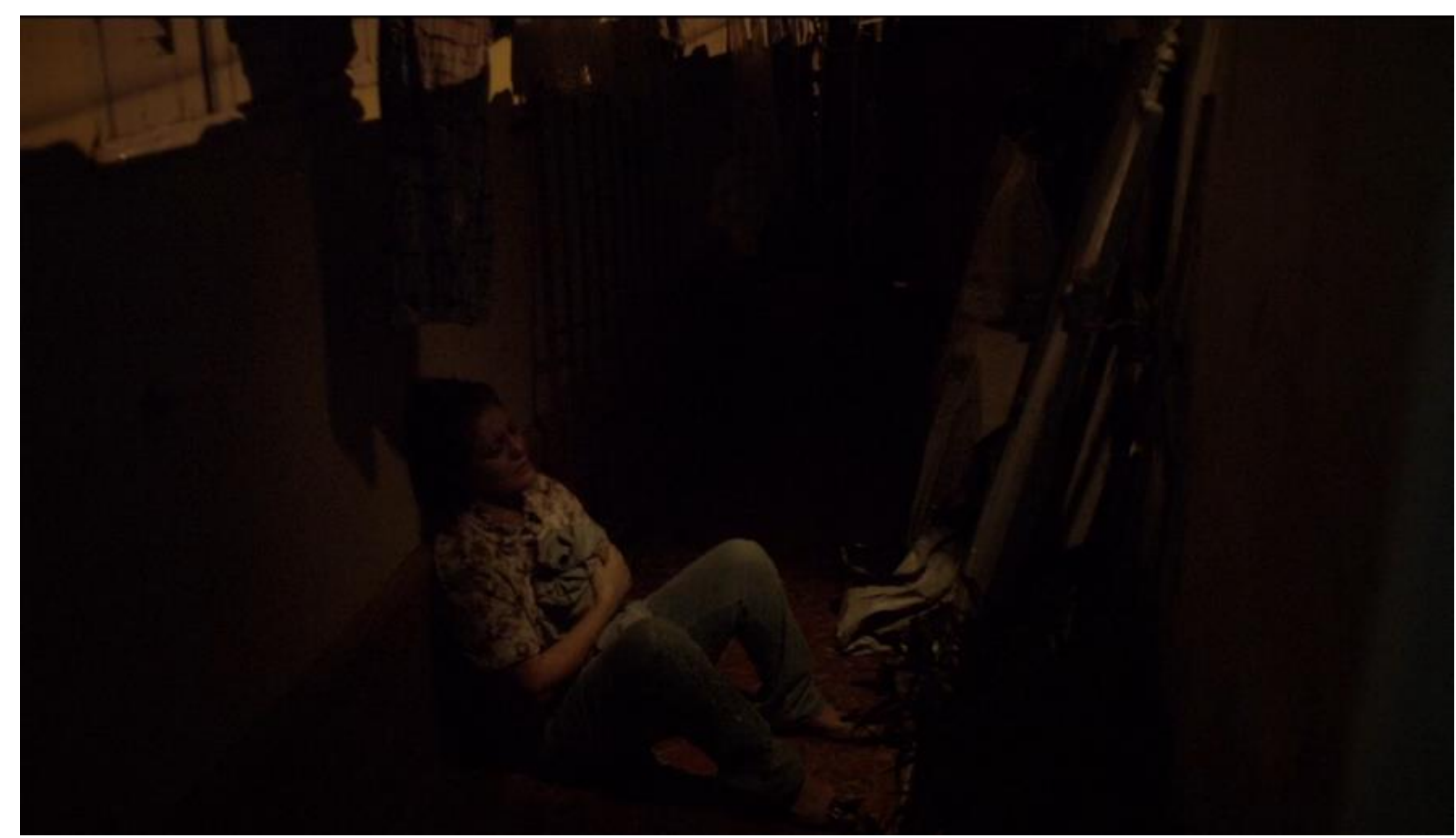

Imagem 16: Após perder o emprego, Rosália se encontra completamente desolada e não sabe lidar com a nova situação, em Pela Janela (Caroline Leone, 2017). (C) Vitrine Filmes. 
Se Rosália é incapaz de perceber novas possibilidades ou enxergar valor em si mesma, além da função profissional que exercia, é porque o peso da necessidade financeira está imbuído também de um peso simbólico. A personagem se culpa por não ser capaz de manter o emprego e se sente perdida, insuficiente, incompleta. Ela se martiriza, refletindo em si mesma a cobrança da sociedade para que a mulher seja perfeita em tudo o que se propõe a realizar, especialmente quando ousa ingressar em um mercado de trabalho antes dominado pela presença masculina. A respeito dessa pressão sentida pelas profissionais do gênero feminino, mesmo aquelas consideradas bem-sucedidas, seja por fatores internos ou externos, Maureen Murdock observa:

\begin{abstract}
"Tudo está centrado em fazer o trabalho bem feito, em escalar os degraus da cadeia acadêmica ou corporativa, obter prestígio, um bom cargo e equidade financeira, em se sentir poderosa no mundo. Essa é uma experiência inebriante para a heroína e completamente apoiada por nossa sociedade materialista, que atribui valor supremo ao que você $f a z$. Qualquer coisa que não seja fazer um 'trabalho importante para o mundo' não tem qualquer valor intrínseco." (MURDOCK, 1990, p. 6)
\end{abstract}

Para uma mulher como Rosália, no momento em que se encontra de sua vida, emancipar-se de tal estrutura aprisionadora é muito difícil - quiçá impossível. Por isso ela demora tanto para começar a superar o fato de não possuir mais a segurança do emprego. Mesmo com todo o esforço de seu irmão para fazê-la perceber que nem tudo está perdido, que há saídas, a sensação de insegurança e de insignificância predominam. Durante boa parte da viagem até a Argentina, a personagem não fala ou sorri, apenas lamenta.

Aos poucos, porém, Rosália passa se abrir às novas experiências que vão se colocando diante dela. Não significa que ela se tornará emancipada ou empoderada, apenas que iniciou uma jornada de compreensão de uma nova realidade, dentro da qual precisará se adaptar. Financeiramente, sua situação permanece incerta: afinal, o mercado de trabalho tende a se fechar para profissionais mais velhos. O máximo que se pode esperar é que os pequenos 
acontecimentos dessa viagem - alguns momentos sentindo a grandiosidade das Cataratas do Iguaçu, a amizade inesperada com uma moça argentina, ou mesmo a compra de um presente para si mesma: uma panela de pressão - possam levar a personagem e compreender que o caminho segue adiante, independentemente dos obstáculos.

\subsection{A emancipação da dependência emocional relacionada à figura masculina}

Entre os fatores que limitam a mulher a uma posição de "outro" na sociedade, talvez o principal deles seja o homem. A visão disseminada em boa parte do mundo há alguns séculos, pela dinâmica patriarcal, determina que o homem seja o sujeito, o ser completo, e a mulher o objeto, ou o homem incompleto; ambos exercendo papéis opostos em uma balança imaginária de valores, com pesos desiguais - ativo versus passivo. Conforme apontou Simone de Beauvoir, em O Segundo Sexo (1949):

"A relação dos dois sexos não é a das duas eletricidades, de dois polos. O homem representa a um tempo o positivo e o neutro, a ponto de dizermos 'os homens' para designar os seres humanos, tendo-se assimilado ao sentido singular do vocábulo latino vir o sentido geral do vocábulo homo. A mulher aparece como o negativo, de modo que toda determinação lhe é imputada como limitação, sem reciprocidade." (BEAUVOIR, 1949, p. 19)

Tal fenômeno se evidencia no corpus da presente pesquisa, especialmente quando a análise se volta para a personagem Hermila, do filme $O$ Céu de Suely (2006). No longa, a própria personagem se coloca em uma posição de passividade com relação aos homens em sua vida: ela sofre para abandonar a dependência (emocional e financeira) de Matheus, o pai de seu filho; ao mesmo tempo em que busca apoio em outra dependência masculina, de João (essencialmente, para alimentar sua autoestima), e se sujeita a depender de um comprador desconhecido, também homem, para sua rifa (de modo a obter dinheiro rápido e realizar seu objetivo de sair da cidade). 
Nesse sentido, Hermila se enquadra na afirmação de Beauvoir de que "a mulher sempre foi, senão a escrava do homem, ao menos sua vassala; os dois sexos nunca partilharam o mundo em igualdade de condições" (BEAUVOIR, 1949). Embora a personagem exista em um mundo contemporâneo, teoricamente mais aberto ao conceito de emancipação do que a realidade de Beauvoir, Hermila parece ver sua existência apenas em relação aos homens que habitam sua vida. Se há dois eixos na jornada por uma consciência de novas possibilidades de ser e agir, a personagem se encontra no eixo que pende para baixo, em um ponto no qual a mulher permanece limitada à sua posição de inferioridade.

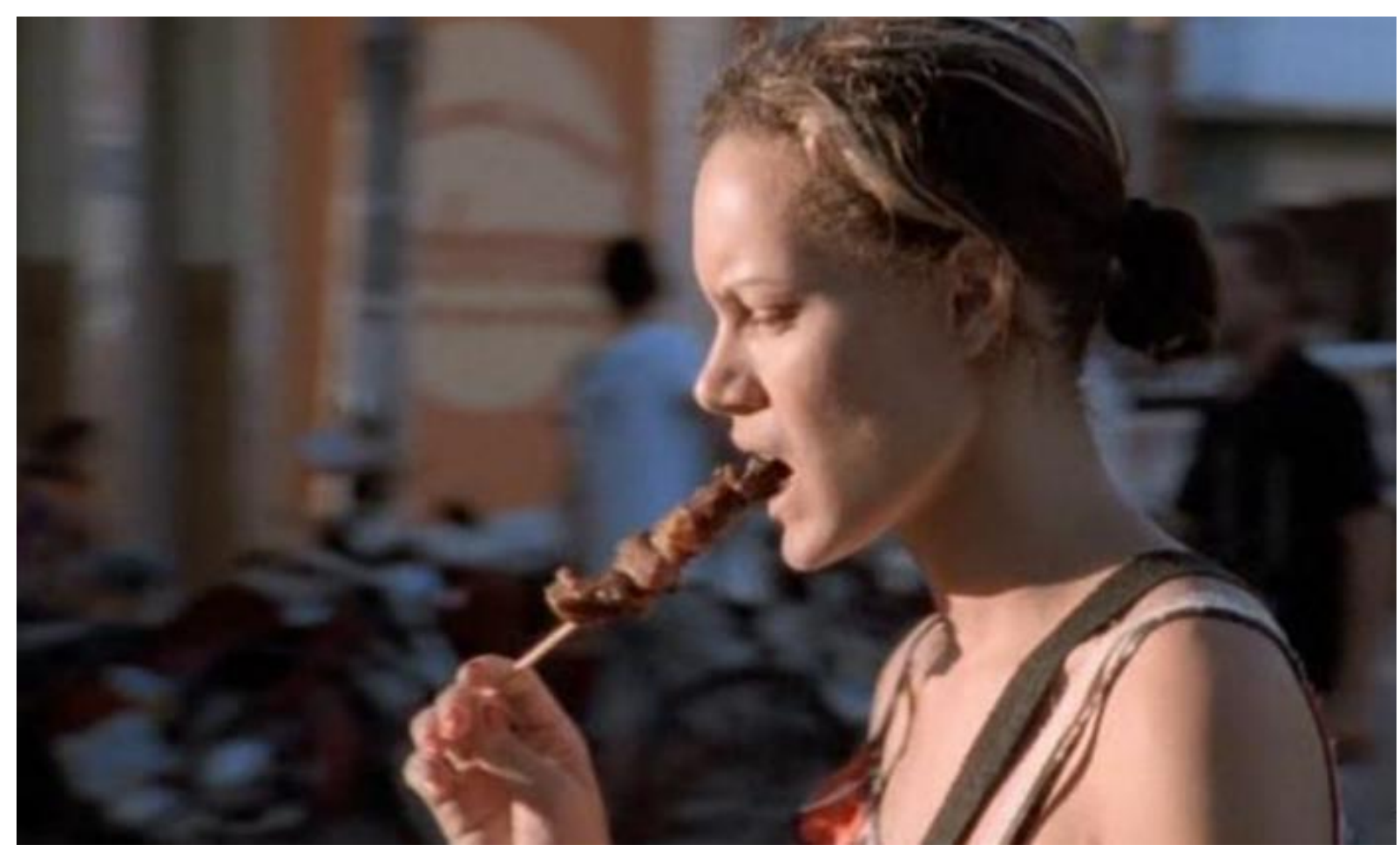

Imagem 17: A própria Hermila se vê apenas como um pedaço de carne a ser vendido e consumido, em $O$ Céu de Suely (Karim Aïnouz, 2006). (O VideoFilmes, Celluloid Dreams, Shotgun Pictures.

Esse movimento (ou falta de) se mostra, muitas vezes, inconsciente. Quando Hermila analisa sua relação com Matheus, ela não vê a própria situação como negativa. Em sua imaturidade romântica, a moça enxerga no homem talvez a única oportunidade de ser feliz. Sua falha - e eventual desilusão - está justamente em não se afirmar como ser individual e autossuficiente, mas depender de um fator externo para se realizar como pessoa. É exatamente 
essa característica, de ver a si mesma como objeto e não como sujeito, que a leva às outras duas dependências: a primeira, relacionada a João, no sentido de se sentir apreciada e valorizada por uma figura masculina, independentemente de quem seja; a segunda, que diz respeito à rifa, submetendo-se a um ato visto por muitos como desprezível, entregando-se uma pessoa que desconhece e usando seu corpo como mera ferramenta, para alcançar uma meta que ela sequer sabe ao certo por que deseja.

Frequentemente, o único "poder" atribuído à mulher é sua feminilidade, sua capacidade de sedução do homem. Talvez seja possível, dentro de uma condição feminina já consciente de seu lugar no mundo, fazer uso do ato sexual para se empoderar e se tornar independente. Contudo, na trajetória de Hermila, a sexualidade como ferramenta se apresenta mais ligada à condição de fraqueza e de subjugação, que se sustenta na validação do dominador. Conforme observa Maureen Murdock, em A Jornada da Heroína (1990):

"A maioria das mulheres procuram poder e autoridade se tornando como homens ou sendo apreciadas por homens. A princípio, isso não é algo negativo, porque buscar a validação masculina é uma transição saudável da fusão com a mãe para uma maior independência na sociedade patriarcal. A jovem mulher que se identifica com o que podem ser consideradas qualidades positivas do pai, como disciplina, tomada de decisões, direção, coragem, poder e amor próprio, encontra-se obtendo sucesso no mundo. Pode ser muito prejudicial, no entanto, se a mulher acredita que ela não existe exceto como um espelho da atenção ou da definição masculinas." (MURDOCK, 1990, p. 37)

Essa posição de relatividade, como se a mulher fosse um astro gravitando em torno da “estrela-homem" - ou, pior, um mero satélite - é reforçada na cultura ocidental pelos contos de fadas. O único papel da donzela é ser resgatada do perigo pelo príncipe encantado, a personificação do herói masculino. Hermila é um retrato da mulher que cresceu com esse paradigma e o persegue de maneira incansável, mesmo em detrimento da própria dignidade. 
Em tal contexto, a transação comercial do corpo, é apenas uma nova forma de dependência do masculino em sua vida.

É curioso que, em uma mulher que não consegue se imaginar sozinha e busca o suporte masculino em uma série de homens que não a veem como ser autônomo, dono de suas próprias decisões, a dependência masculina da qual Hermila tenta se libertar se percebe somente na relação com o filho - o único homem que realmente depende dela na história. Em sua aparente falta de "instinto materno", a jovem recusa esse masculino vulnerável, talvez porque ele espelha suas próprias vulnerabilidades. Ao mesmo tempo em que se desconecta do filho, ela é incapaz de se desprender das amarras que a mantém apegada a Matheus, o pai e marido ausente, por vezes projetando em outro homem (João, o namorado) uma necessidade emocional não suprida. O não cumprimento de sua função esperada na maternidade, inclusive perante o ato de "deixar para trás" o filho, quando Hermila opta por ir embora de Iguatu sozinha, é a única pequena rebeldia que a personagem se permite, dentro de um sistema que a limita a papéis - restritos a dois extremos, considerados como parte da natureza feminina: o da fêmea procriadora/objeto sexual ou o da mãe/cuidadora.

"A mulher? É muito simples, dizem os amadores de fórmulas simples: é uma matriz, um ovário; é uma fêmea, e esta palavra basta para defini-la. Na boca do homem o epíteto 'fêmea' soa como um insulto; no entanto, ele não se envergonha de sua animalidade, sente-se, ao contrário, orgulhoso se dele dizem: 'É um macho!' O termo 'fêmea' é pejorativo não porque enraíza a mulher na Natureza, mas porque a confina no seu sexo." (BEAUVOIR, 1949, p. 32)

O ato extremo, ao final de $O$ Céu de Suely, de abrir mão da convivência com o filho, pode ser confundido por muitos com egoísmo. Afinal, a mulher não possui o mesmo direito que o homem de se afastar voluntariamente de sua prole. Não é possível saber se ela retornará para buscar o filho e participar da vida dele, futuramente, ou se acabará alimentando arrependimentos por conta dessa separação - como foi o caso de Val, em Que Horas Ela 
Volta?. Por isso, a partida de Hermila não pode considerada um movimento real de emancipação, porque das presenças masculinas em sua vida, o filho seria a menos danosa - e a única da qual ela não se encontrava, de fato, dependente.

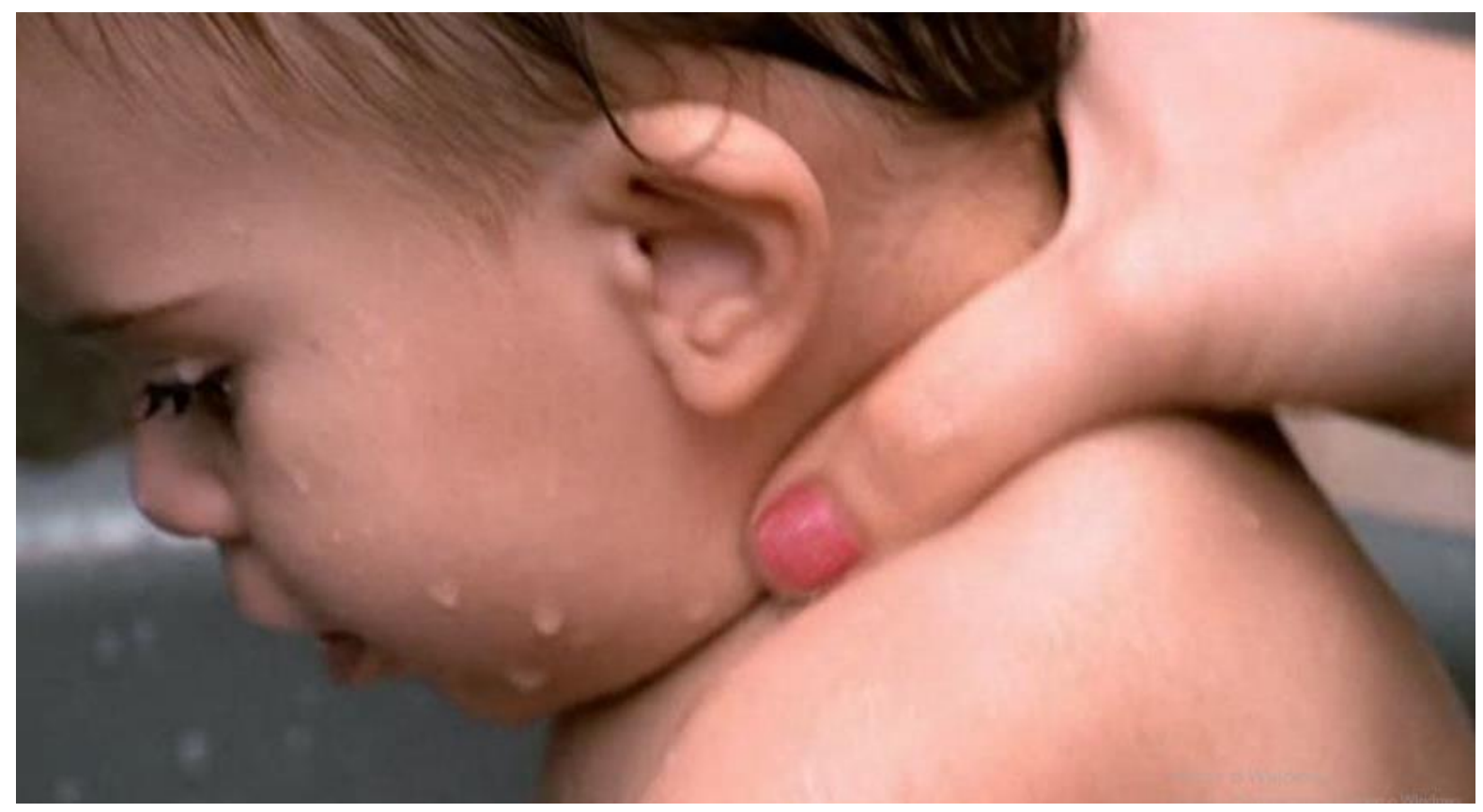

Imagem 18: Hermila dá banho no filho, antes de embarcar no ônibus, em O Céu de Suely (Karim Aïnouz, 2006). Os dois não aparecem juntos em quadro em nenhum momento da cena. (C) VideoFilmes, Celluloid Dreams, Shotgun Pictures.

Vale ressaltar que deixar os filhos aos cuidados de outros é, para muitas mulheres, uma questão de necessidade e sobrevivência, principalmente quando se trata de movimentos migratórios. A estrutura familiar, então, se torna responsável pela criação desse filho, o que pode vir a ser positivo para a criança. A própria escolha de rifar o corpo é ambivalente, em seu aspecto de desqualificação da jornada emancipatória da personagem, porque não deixa de ser uma tentativa de se emancipar financeiramente. O que a análise observou, no entanto, é que as ações da personagem, ainda que em certos momentos fundamentadas em uma intenção de independência, revelam-se mais como fuga de sua realidade e não a levam a uma autonomia concreta, dentro do espaço diegético observado. 
Ao contrário de Hermila, a personagem Val, de Que Horas Ela Volta? (2015), de certa forma eliminou a presença - e, consequentemente, a dependência - masculina em sua vida. Se, por um lado, Hermila se encontra no eixo de quase completa dependência dos homens em sua vida, Val habita o eixo mais próximo da emancipação nesse sentido. Afinal, o pai de sua filha deixou de fazer parte de sua vida há mais de uma década. Além disso, no ponto de sua jornada em que a história acontece, ela não possui relacionamentos amorosos, embora apresente uma vida social ativa.

A única figura masculina relevante em sua existência é a de Fabinho, o filho da patroa, que demonstra clara dependência emocional da empregada, possivelmente para suprir suas próprias carências de afeto materno. A relação apresenta também certo nível de toxicidade, embora Fabinho visivelmente ame e respeite Val; isso porque ele faz uso da afetividade e do conforto dados por ela, mas sem oferecer reciprocidade em igual medida. Enquanto Val abre mão de seu próprio tempo e bem-estar para satisfazer os caprichos do rapaz, dispondo-se a ouvi-lo e atuando como uma espécie de "muleta emocional" em sua vida, sem pedir qualquer coisa em troca, Fabinho não demonstra muito interesse em perguntar sobre os problemas ou angústias vividos pela empregada, no âmbito pessoal.

"O homem pode, pois, persuadir-se de que não existe mais hierarquia social entre os sexos e de que, grosso modo, através das diferenças, a mulher é sua igual. Como observa, entretanto, algumas inferioridades - das quais a mais importante é a incapacidade profissional -, ele as atribui à natureza. Quando tem para com a mulher uma atitude de colaboração e benevolência, ele tematiza o princípio da igualdade abstrata; e a desigualdade concreta que verifica, ele não a expõe. Mas, logo que entra em conflito com a mulher, a situação se inverte: ele tematiza a desigualdade concreta e dela tira autoridade para negar a igualdade abstrata. Assim é que muitos homens afirmam quase com boa-fé que as mulheres são iguais aos homens e nada têm a reivindicar, e, ao mesmo tempo, que as mulheres nunca poderão ser iguais aos homens e que suas reivindicações são vãs." (BEAUVOIR, 1949, p. 26) 
No caso de Fabinho, a inferiorização das necessidades ou desejos de Val com relação às suas próprias carências acontece de forma quase instintiva. Ele faz parte de um sistema, herdeiro da dinâmica feudal, no qual existe uma ilusão de igualdade entre patrões e servos; porém, na prática, as duas classes habitam universos completamente diversos dentro de uma mesma casa. Os patrões se esforçam para manter a farsa de que a funcionária é "quase da família”, embora seja evidente sua posição de inferioridade. Não obstante, o rapaz sente-se no direito de usar Val como ponto de apoio emocional, como se essa fosse uma das funções dela como empregada da casa. Embora exista um laço concreto de carinho, trata-se de uma relação complexa e, em muitos aspectos, desigual - pelo menos no que diz respeito à disponibilidade de dar ou de receber das partes envolvidas.

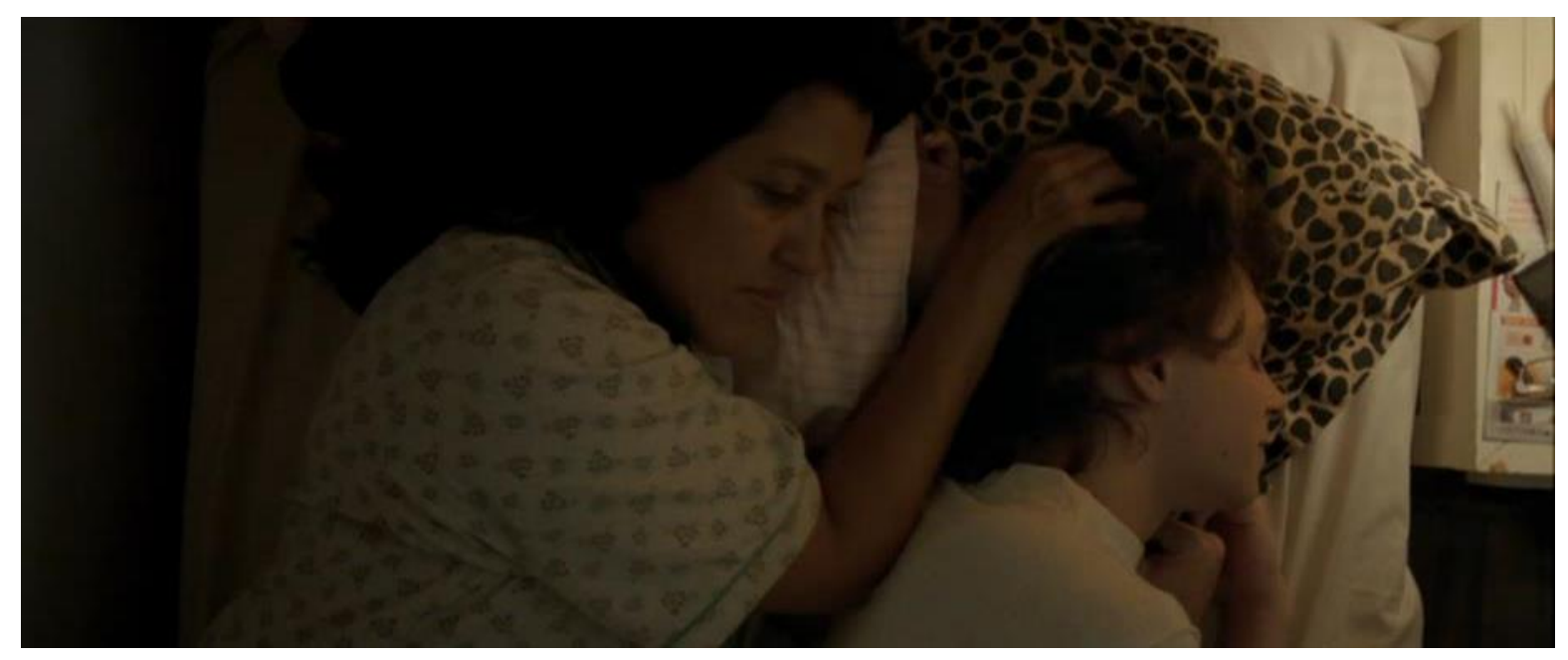

Imagem 19: A relação de Val com Fabinho, única figura masculina de relevância para ela em Que Horas Ela Volta? (Anna Muylaert, 2015), é de desigualdade. (C Globo Filmes, Gullane Filmes, África Filmes, Pandora Filmes.

Embora Val cumpra, por meio de Fabinho, o papel de cuidadora que é constantemente delegado à natureza feminina (o mesmo papel, diga-se, que ela não pode exercer com a própria filha, Jéssica), a personagem se mostra, de forma geral, como um ser independente e dinâmico, com uma vida completa em si mesma. Exceto pela conexão com o filho da patroa, Val é livre de qualquer dependência masculina, seja emocional ou financeira. Nessa narrativa, 
não há "homem como o ativo para levar a história adiante" (MULVEY, 1979). De forma crescente ao longo do desenvolvimento de sua trajetória, a protagonista age como sujeito autônomo da própria história.

Jéssica, a filha de $\mathrm{Val}$, se posiciona na própria jornada de maneira ainda mais emancipada do que a mãe. Mesmo muito jovem, ela já foi capaz de desconstruir as estruturas patriarcais do mundo em que vive e descobriu seu próprio poder de tomada de decisões, independentemente do que os homens à sua volta possam querer ou dizer. Um exemplo disso é sua autonomia para resistir às investidas do patrão de Val, Carlos (interpretado por Lourenço Mutarelli), um homem muito mais velho e que tecnicamente se encontraria em uma hierarquia de poder acima da sua. $\mathrm{O}$ apelo masculino, mesmo de Fabinho e de seus amigos, que são jovens da sua idade, não representa para Jéssica nenhuma ameaça à sua independência ou autonomia.

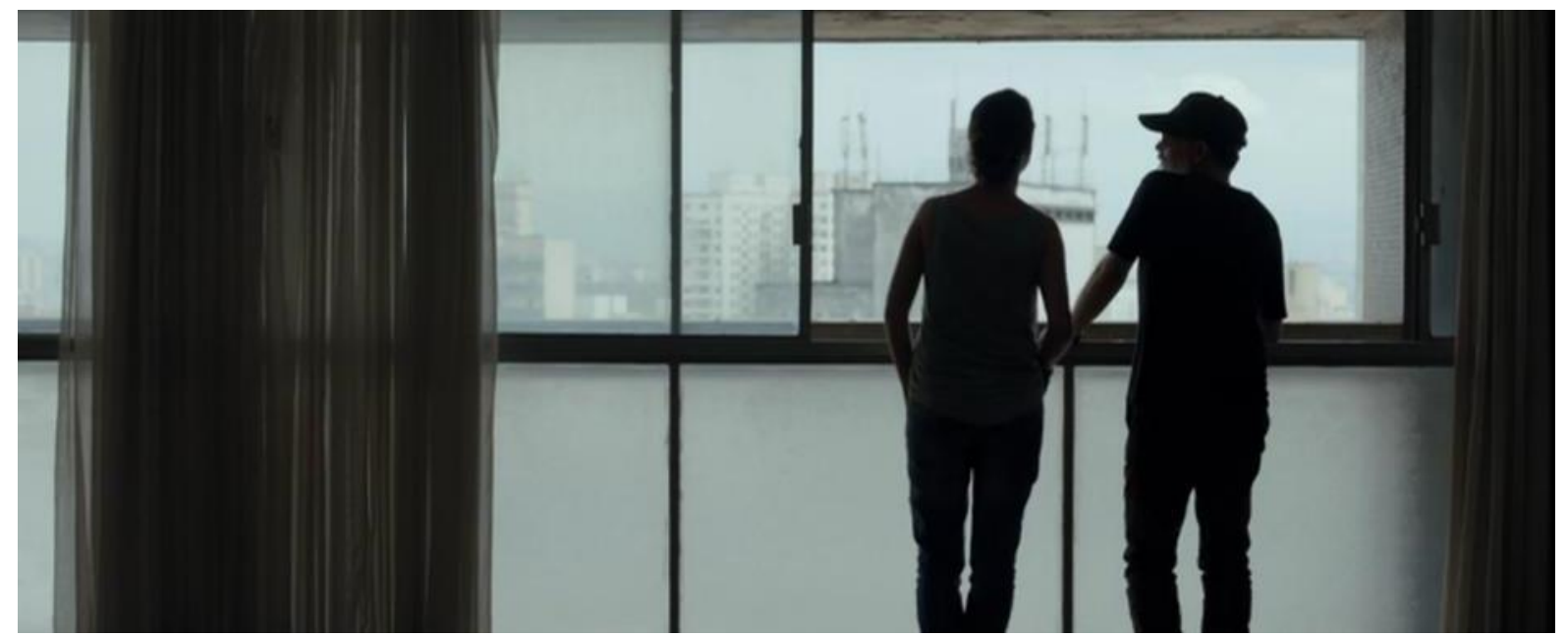

Imagem 20: A personagem Jéssica se mostra totalmente emancipada da dependência masculina, em Que Horas Ela Volta? (2015). @ Globo Filmes, Gullane Filmes, África Filmes, Pandora Filmes.

Na dinâmica de poder entre Jéssica e Carlos, a garota se coloca como indivíduo forte e dono de suas ações, enquanto o homem abre mão de sua virilidade para se colocar como a parte mais frágil da relação. Ela não se sente atraída por ele; portanto, também não se sente na obrigação de satisfazê-lo - como acontece com muitas mulheres, instintivamente, acedendo às 
posturas e desejos masculinos pelo simples fato de terem sido doutrinadas a buscar a aceitação masculina para se sentirem validadas. Essa consciência de Jéssica sobre si mesma é parte integral de seu processo de emancipação, muito mais avançado que o de todas as demais personagens estudadas, já que "uma vida é uma relação com o mundo; é escolhendo-se através do mundo que o indivíduo se define" (BEAUVOIR, 1949, p. 67). Em sua relação com o mundo e com os homens, Jéssica não deseja se identificar com o masculino, nem ser resgatada por ele.

Em uma sociedade orientada por normas masculinas, em que o padrão social relacionado à liderança, autonomia e sucesso está ligado fundamentalmente ao homem, sendo as mulheres percebidas como seres em falta de competência, inteligência e poder (MURDOCK, 1990, p. 29), Jéssica se comporta como se, apesar de sua juventude, já tivesse aprendido a ignorar esses paradigmas e se bastar em si mesma. Sua busca por inclusão em um curso superior elitizado revela que, mais do que simples musa de um homem, essa mulher deseja ser a protagonista de uma história diferente daquela que lhe seria "destinada" inicialmente, por sua condição social. "A partir do momento em que a mulher é encarada como pessoa, só pode ser conquistada com seu consentimento: cumpre vencê-la" (BEAUVOIR, 1949, p. 196). Jéssica não se submete, nem consente ao que não lhe agrada, porque seu objetivo primordial é agradar a si mesma. Ela não precisa de um homem para defini-la, porque - diferentemente de personagens como Hermila e Rosália - não se sente de maneira alguma inferior ao ser masculino.

"O privilégio econômico detido pelos homens, seu valor social, o prestígio do casamento, a utilidade de um apoio masculino, tudo impele as mulheres a desejarem ardorosamente agradar aos homens. Em conjunto, elas ainda se encontram em situação de vassalas. Disso decorre que a mulher se conhece e se escolhe, não tal como existe para si, mas tal qual o homem a define. (p. 155)" (BEAUVOIR, 1949, p. 26) 
Por se conhecer e escolher primeiramente a si mesma, a personagem emancipada escapa das amarras da dependência e da subserviência, que são impostas desde a infância, muitas vezes de forma inconsciente, à maior parte das mulheres. Esse comportamento independente, que não se permite dominar ou ser definida por homens, pode ser observado tanto em Jéssica quanto em Val. Portanto, retornando à protagonista "oficial" de Que Horas Ela Volta?, Val demonstra uma emancipação semelhante da dependência masculina, mas em seu contexto específico. Ela não busca se adaptar às expectativas que a sociedade tem em relação ao ser feminino, nem faz esforço algum para se encaixar em um relacionamento romântico que não lhe seja agregador. Embora o comportamento servil e dócil da personagem com relação à sua condição empregatícia seja uma limitação de suas possibilidades limitação essa que é rompida, quando Val se demite do cargo que a oprime, ampliando ainda mais sua jornada emancipatória - a personagem não se encontra em situação de dependência com relação a nenhuma figura masculina.

\begin{abstract}
"Se as mulheres veem a si mesmas através de uma lente masculina, e continuamente se medem pelos padrões de uma cultura definida pelo masculino, elas se perceberão deficientes ou em falta das qualidades que os homens valorizam. As mulheres nunca serão homens, e muitas mulheres que tentam ser 'tão boas quanto homens' estão prejudicando sua natureza feminina. As mulheres começam a se definir em termos de faltas, em termos do que não possuem ou do que não conquistaram, e passam a obscurecer ou desvalorizar a si mesmas como mulheres.” (MURDOCK, 1990, p. 14)
\end{abstract}

A afirmação de Murdock fala muito sobre a condição de Rosália, em Pela Janela (2017). Enquanto Val já inicia sua história no espectro de uma mulher que obteve certa emancipação, que não nega nem desvaloriza sua condição feminina, por mais penosa que ela possa ser (arcando com as consequências do afastamento da filha e o julgamento social pelo "abandono materno", por exemplo), e Hermila se posiciona no espectro oposto, da mulher que não se libertou em nenhum aspecto da dependência masculina, Rosália está em uma condição 
neutra de total autoanulação, em nenhum dos extremos do processo emancipatório - uma espécie de "não ser".

Em Pela Janela, a personagem não se mostra apenas dependente emocionalmente do irmão, mas de um sistema que impõe a subserviência ao masculino como sendo um ideal de vida para as mulheres. É com o irmão que Rosália divide a casa onde mora, é ele também o motivador da viagem para a Argentina. Contudo, o relacionamento entre os dois se define como um vínculo de conveniência. Ambos são sozinhos, já não são jovens e precisam de companhia; um ajuda ao outro. Há, certamente, momentos em que ela se permite demonstrar traços de uma personalidade enterrada sob a fachada de subserviência - sobretudo nas cenas do filme em que abandona a falsa timidez e canta, libertando-se momentaneamente para ser alguém. Porém, essas breves fagulhas de libertação são obscurecidas por um cotidiano apagado, repetitivo e sem perspectivas.

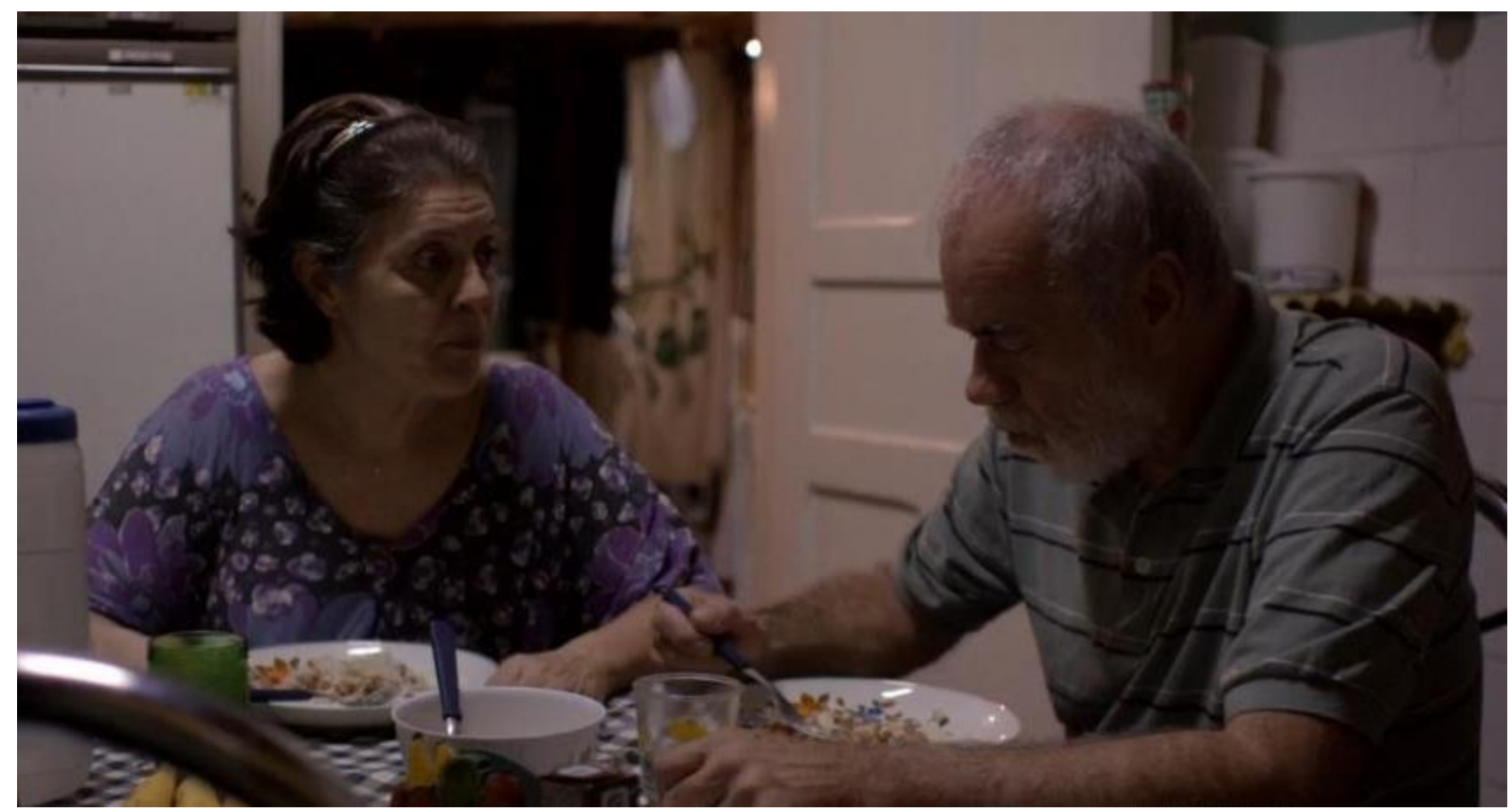

Imagem 21: Um relacionamento de conveniência define a vida de Rosália e seu irmão, em Pela Janela (Caroline Leone, 2017). () Vitrine Filmes.

Em sua jornada, Rosália demonstra uma dependência moral a uma ideia de como deveria viver sua vida. Embora não tenha se casado, ou não possua relacionamentos amorosos 
dignos de conhecimento (pelo menos no espaço diegético do longa-metragem), Rosália cumpre um papel de "esposa subserviente", uma "Amélia"11", em todos os âmbitos de sua existência. Ela transferiu essa carga amorosa e submissa para o trabalho e a família - uma transferência pela ausência. Na sobrevivência obstinada das tradições mais antigas, "abrem-se as fábricas, os escritórios, as faculdades às mulheres, mas continua-se a considerar que o casamento é para elas uma carreira das mais honrosas e que as dispensa de qualquer outra participação na vida coletiva." (BEAUVOIR, 1949, p. 154)

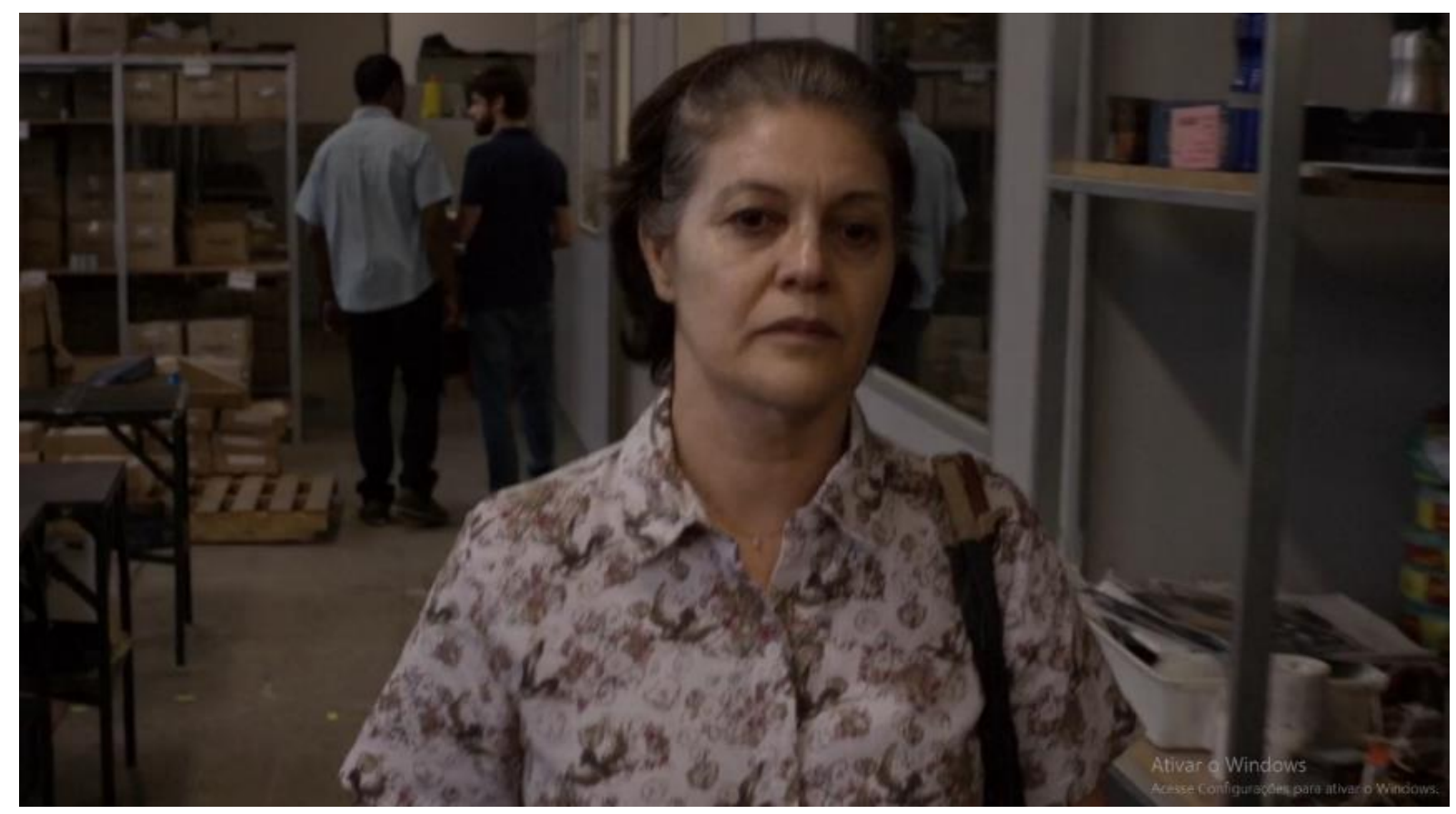

Imagem 22: Rosália transfere para o ambiente profissional o comportamento de uma esposa servil, em Pela Janela (Caroline Leone, 2017). (C) Vitrine Filmes.

No trabalho, Rosália cumpre as tarefas de maneira quase obsessiva, buscando constantemente a aprovação de superiores (homens) que não a valorizam e acabam por descartá-la, como se a funcionária nada significasse. A mulher apenas obedece às ordens, calada, não se permitindo questionar ou demonstrar personalidade. Esse comportamento não se altera, nem mesmo quando ela é demitida do cargo que ocupa há tantos anos. Sua

${ }^{11} \mathrm{O}$ nome, que hoje é associado a uma postura de mulher submissa, originou-se com a canção Ai! que saudade da Amélia (comumente chamada somente de Amélia), composta por Mário Lago (letra) e Ataulfo Alves (revisão e música) e lançada em 1942. 
subsequente depressão reflete a de uma recém-divorciada, ainda em negação, que não é capaz de conceber como poderá prosseguir com sua vida após a separação. Tanto que a personagem chega a retornar à fábrica, mesmo após a demissão, para oferecer ajuda ao seu substituto.

Na falta da figura do marido em sua vida, Rosália também projeta no relacionamento com o irmão um modelo que não viveu, mas que é lhe imposto socialmente, realizando com docilidade e resignação as tarefas domésticas - lavar e guardar a roupa, bordar, fazer café, preparar a comida - e cuidando dele como cuidaria de um cônjuge. Assim, encaixa-se no padrão citado por Simone de Beauvoir do comportamento feminino esperado pela sociedade patriarcal: "A mulher é por excelência a argila que se deixa passivamente malaxar e moldar; mas, cedendo, ela resiste, o que permite à ação masculina perpetuar-se. A matéria demasiado plástica anula-se pela sua docilidade [...]” (BEAUVOIR, 1949, p. 189).

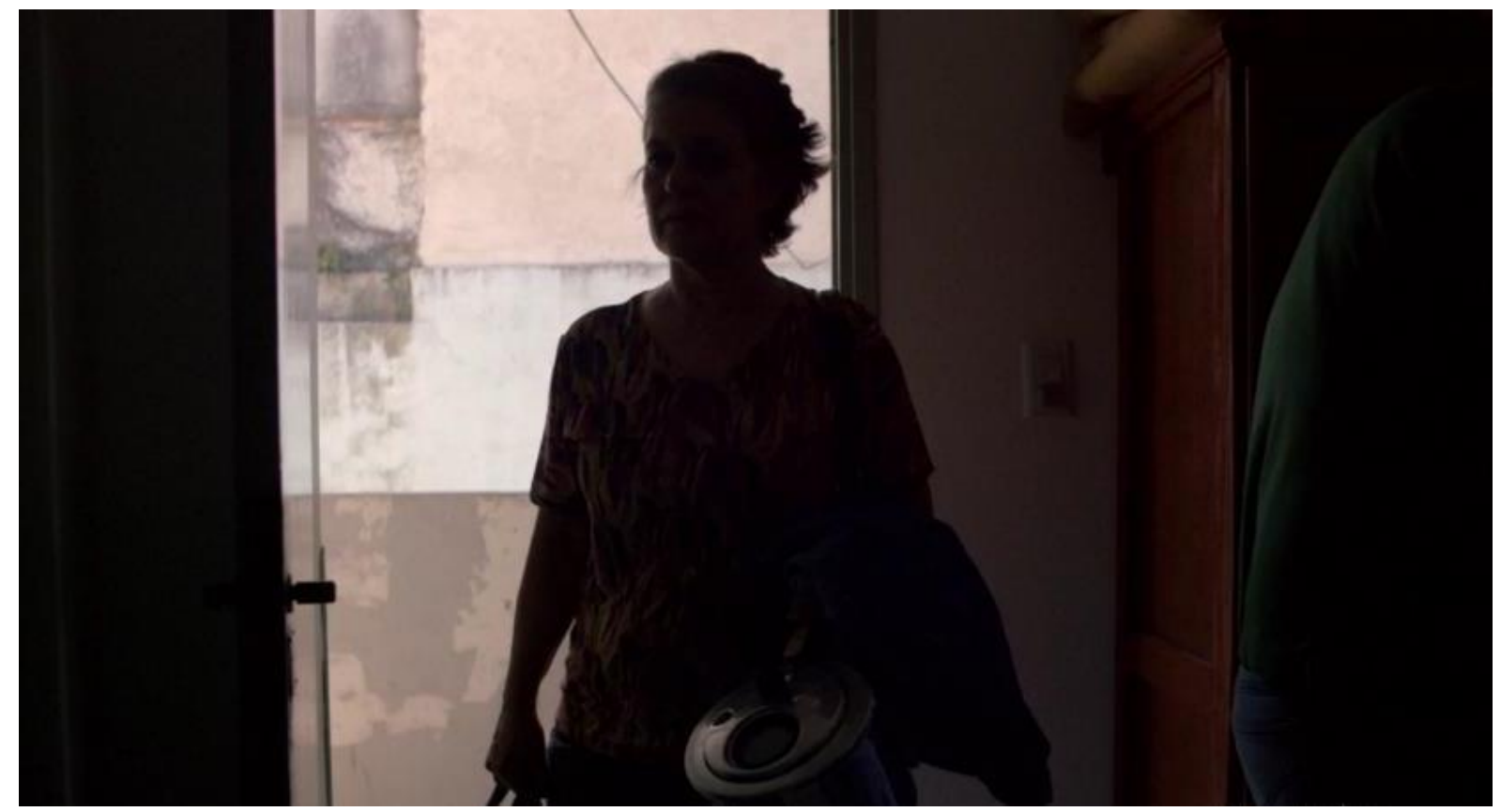

Imagem 23: Trilhando um caminho traçado por convenções sociais, Rosália é um ser que inexiste, em Pela Janela (Caroline Leone, 2017). (C) Vitrine Filmes.

Como pode Rosália ser submissa a um modelo que não viveu, mas que está praticamente impresso em seu subconsciente? Ela foi moldada por uma abstração social, no nível mais perverso possível, porque se trata de uma manipulação lenta e silenciosa. "E, 
provavelmente, é mais confortável suportar uma escravidão cega que trabalhar para se libertar: os mortos também estão mais bem adaptados à terra do que os vivos” (BEAUVOIR, 1949, pg. 260). Encontrando-se dentro de um mundo dominado pelo masculino, sem adquirir a consciência de sua própria força individual, ela simplesmente foi vivendo; porém, sem se permitir viver, de fato. Tornou-se dependente de uma figura que não existe: um ideal de homem que finalmente acabaria por vê-la por quem ela é, que valorizaria seus esforços e todo o seu trabalho duro para ser a mulher "esperada".

Podemos concluir, desse modo, que os fatores que impelem Rosália são sobretudo gerados por uma constituição moral, não existencial ou pessoal. Sua passividade perante a própria vida não está relacionada a escolhas ou ao destino, mas a convenções sociais que moldaram seu perfil como o de um ser que inexiste. Depois de tanto se negar e se fechar para o mundo, ela acabou se anulando e sendo anulada. Por isso, a personagem se coloca em um ponto peculiar, no eixo de análise (em que Hermila e Val se posicionam como oponentes, cada uma seguindo em uma direção): o ponto neutro. Rosália vive a vida que não foi, a vida que não é. Trata-se de uma vida dura, essa; motivo pelo qual ela se mostra tão ressentida.

Ou seja, partindo da afirmação de que

"Libertar a mulher é recusar encerrá-la nas relações que mantém com o homem, mas não as negar; ainda que ela se ponha para si, não deixará de existir também para ele: reconhecendo-se mutuamente como sujeito, cada um permanecerá entretanto um outro para o outro." (BEAUVOIR, 1949, pg. 701)

poderíamos afirmar que, dentro do diagrama de pensamento abordado, Val se libertou, Hermila ainda se encontra presa e Rosália se mantém em um ponto de anulação completa, que a leva ao caminho inverso do que Beauvoir aponta: ela deixa de existir, tanto para o homem quanto para si mesma, pois não é capaz de se reconhecer como sujeito; não como resultado de um ato de "não querer", mas simplesmente por uma condição imposta pela sociedade que a personagem se forçou a representar, repetidamente. 


\section{Capítulo 3: O protagonismo como processo gradativo e contraditório}

Embora os tempos atuais ofereçam enormes possibilidades de autoconhecimento e desconstrução, para a mulher contemporânea, a jornada rumo à emancipação - tanto financeira quanto da dominação masculina - ainda é um grande desafio. Trata-se de uma aventura que exige sacrifícios e consciência de suas próprias capacidades. Tomando o exemplo do herói de Campbell, no primeiro estágio de sua jornada mitológica, quando o destino o convoca para uma região desconhecida: "Um erro - aparentemente um mero acaso revela um mundo insuspeito, e o indivíduo entra numa relação com forças que não são plenamente compreendidas" (CAMPBELL, 1949, p. 31). Na jornada das heroínas, essa relação de forças não raro as coloca em posição de inferioridade e, mesmo quando as mulheres compreendem essa dinâmica, nem sempre são capazes de se libertarem dela.

No caso de Hermila, o chamado à aventura a levou para Iguatu, sua pequena e árida cidade. O filme se inicia com uma sequência quase onírica, ao som de uma versão da música Everything I Own, de David Gates - em português, Tudo Que Eu Tenho, na voz de Diana. A letra melancólica fala de um amor perdido, porém não esquecido, terminando com os versos: “Tudo que eu tenho, meu bem, é você / Volte logo, meu amor" - o que, viremos a saber, não irá acontecer, já que a personagem é abandonada pelo homem que ama. A cena é também o único momento em que o personagem Matheus (o pai do filho de Hermila) aparece no longametragem, o que torna seu posterior "desaparecimento" da vida dela ainda mais contundente. Analisando os elementos fílmicos, torna-se evidente que tudo o que ela tem não passa de um sonho, uma ilusão que irá se desvanecer tão logo a música se acabe. Não por coincidência, outros momentos marcantes nos quais uma trilha sonora (ainda que somente instrumental) se mostra presente são as cenas em que Hermila se desilude com a espera em vão por Matheus na rodoviária, o primeiro passeio de moto com João e, finalmente, a partida dela de Iguatu. 


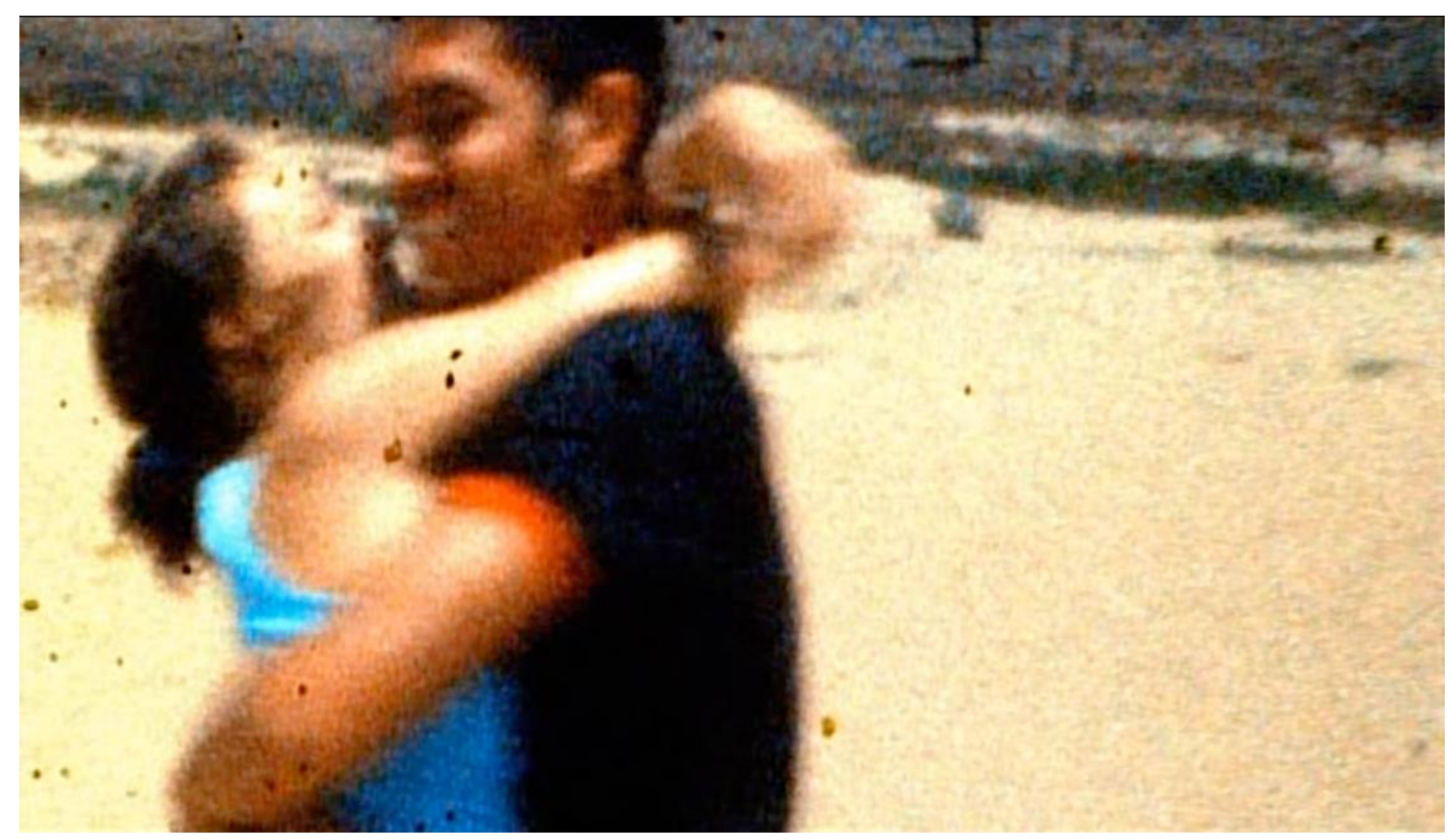

Imagem 24: Cena da abertura de $O$ Céu de Suely (Karim Aïnouz, 2006), na qual aparecem Hermila e Matheus. (C) VideoFilmes, Celluloid Dreams, Shotgun Pictures.

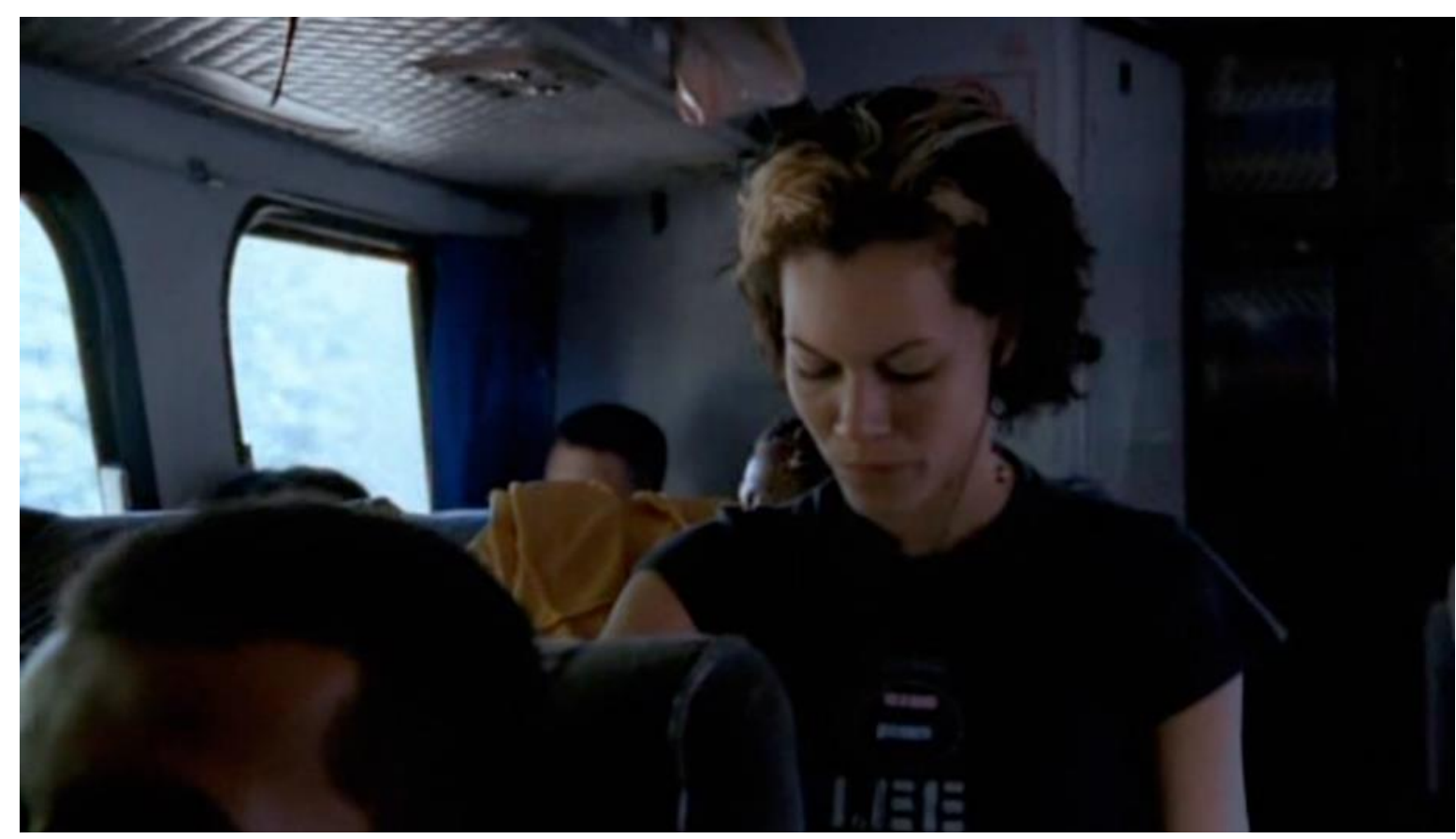

Imagem 25: Choque de realidade: a personagem Hermila, no ônibus, a caminho de Iguatu. (C) VideoFilmes, Celluloid Dreams, Shotgun Pictures.

Quando o espectador é, de fato, apresentado à realidade da protagonista, essa apresentação se dá por meio de um plano próximo dos olhos de Hermila, que revela tensão e 
inquietude. É visível o contraste de sentimentos entre o ideal romântico que ela imaginava para sua vida e o momento que está vivendo, na longa e tortuosa viagem com o filho pequeno, a caminho de sua terra natal. As cores de seu figurino agora são escuras, seu semblante é triste e preocupado; o ambiente não é mais um campo aberto, mas um espaço limitado e opressivo; a trilha sonora foi substituída pelo barulho do motor do ônibus. Sem dinheiro e sem o "homem de sua vida", retornando relutantemente às origens, sua face é o retrato de uma mulher cujos planos fracassaram. Ela é a representação de uma protagonista sem protagonismo na própria vida, que não poderia estar mais longe da emancipação.

A placa da cidade afirma: “Aqui começa Iguatu”. Contudo, tanto o semblante da personagem quanto a paisagem solitária e desértica do local denotam que ali as estradas não levam a lugar algum: elas apenas terminam. Tudo remete à estagnação, desde o chão batido e os casebres humildes até o canto tardio de um galo e os ruídos da engrenagem de uma bicicleta enferrujada. Conforme descreveu o roteirista e assistente de direção Felipe Bragança, em carta publicada na Revista Contracampo (2005), quando o longa-metragem ainda se chamava Rifa-me:

"Iguatu não existe. É um nada e ao mesmo tempo é tudo o que existe no mundo. Um desejo imenso inacabado e uma sujeira de vontades atravessadas, ecoadas, como se sonhos do mundo todo encontrassem aqui o lugar de se perder... e de deixar as suas sombras. Iguatu é o deserto e o centro do mundo. E o absoluto e o imprevisível. Um abismo de cores e luzes frias, de néons que são como a resposta silenciosa ao chão seco em que se pisa, para o céu lavado ao qual se olha." (BRAGANÇA, 2005)

Quando Hermila desembarca do ônibus no meio do nada, ela é posicionada em um plano aberto que chega a ser opressivo em relação à personagem, no qual o céu ocupa a maior parte do enquadramento e a jovem parece achatada pelo chão árido e sem vida do sertão. $\mathrm{O}$ cenário simples, deserto e fustigado pelo sol, é o indicativo visual de uma realidade na qual a protagonista desembarca sem condições financeiras de exercer qualquer protagonismo. Essa 
aridez se expressa em diversos elementos fílmicos no decorrer da narrativa: Hermila deitada no chão em frente à casa da avó, à noite, fumando e ouvindo o choro de seu filho (fora de quadro); Hermila parada junto a um telefone público, enquadrada de longe, enquanto suas ligações são constantemente ignoradas pelo ex-marido; Hermila com o bebê nos braços, voltando da casa da ex-sogra, mãe de Matheus, após receber dela a notícia de que ele realmente não tem planos de voltar; Hermila caminhando sozinha pela rodoviária, quando Matheus não chega em Iguatu na data combinada. Nas cenas em que aparece só, Hermila tende a observar inexpressivamente o céu ou a paisagem desolada do sertão, como se contemplasse seus próprios sonhos frustrados e projetos jamais concretizados. Até mesmo a cena em que ela está voltando da "noite no paraíso" com o vencedor de sua rifa, quando a personagem olha para uma árvore seca no meio do nada, demonstra o quanto a jovem está enraizada em um local que não lhe permite florescer em seus anseios pessoais.

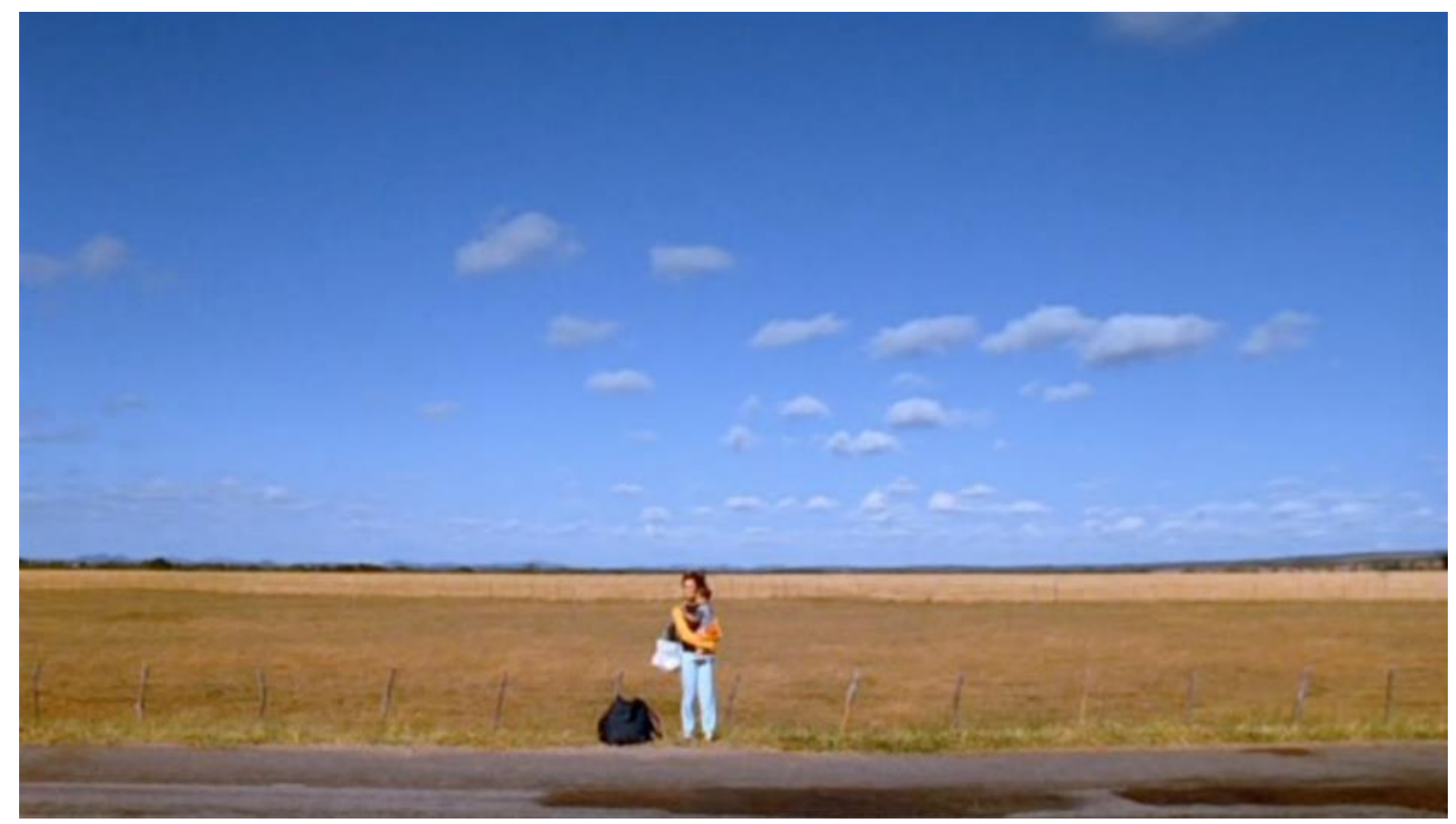

Imagem 26: Hermila, chega a Iguatu, em imagem que expressa o vazio da paisagem. (C) VideoFilmes, Celluloid Dreams, Shotgun Pictures. 


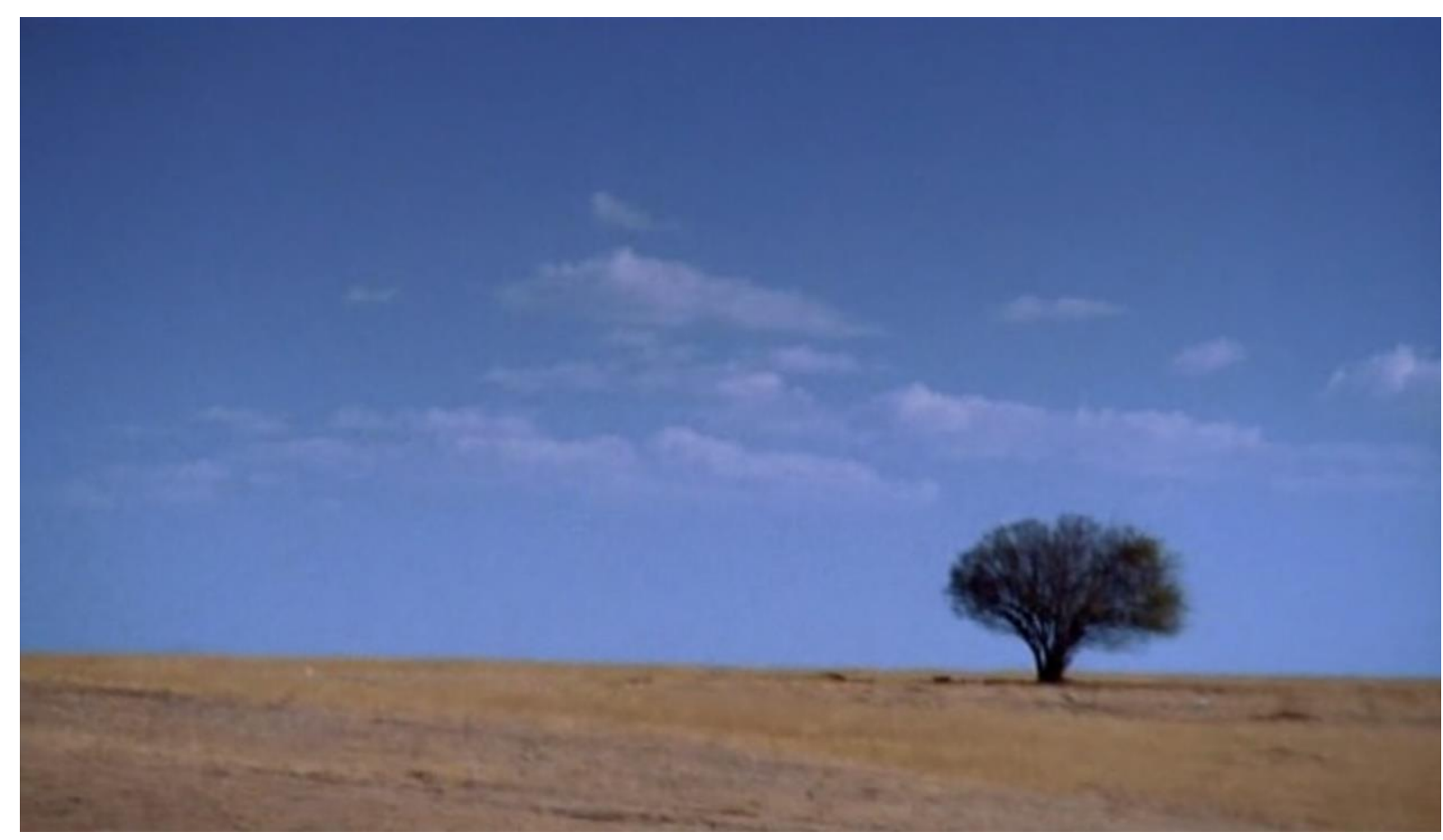

Imagem 27: A árvore presa a uma terra infértil, no meio do nada, representa Hermila. (C) VideoFilmes, Celluloid Dreams, Shotgun Pictures.

Após a chegada em Iguatu, sentada em um posto de gasolina, com o filho em prantos nos braços, Hermila espera por sua tia, Maria (interpretada por Maria Menezes) ${ }^{12}$. A chegada da tia torna a expressão de Hermila mais leve - um primeiro sinal da importância que a rede de apoio familiar terá em sua jornada. Esse mesmo cuidado é visto quando elas chegam na casa da avó de Hermila, Zezita (Zezita Matos), que faz questão de dar banho e alimentar o bisneto. Essa demonstração de cuidado contrasta com a aparente falta de "instinto materno" demonstrada por Hermila, que chega a afirmar, sobre o garoto: “Às vezes dá vontade de deixar ele no mato e sair correndo". No decorrer da história, sua relação com a maternidade e as obrigações por ela impostas é dúbia, ao mesmo tempo em que ela tenta vislumbrar saídas tanto para a desesperança emocional quanto financeira.

\footnotetext{
12 A escolha dos nomes dos atores para denominar os personagens não é circunstancial. Os realizadores buscaram manter a maior quantidade possível de elementos reais, para emprestar autenticidade à trama. Uma cena subsequente, por exemplo, na qual Hermila vende rifas, foi gravada de longe, sem que os compradores soubessem que faziam parte de um filme. (BARBOSA, BUCK, MAZETTO, NARDIN, SILVA, 2014)
} 
O ponto de mudança na trajetória de Hermila se inicia a partir do momento em que ela encontra uma nova aliada, com quem se identifica e estabelece uma conexão imediata: Georgina, garota de programa que se torna amiga da protagonista. Quando Hermila percebe que Matheus não irá para Iguatu encontrá-la e que precisará traçar seu próprio caminho sem uma presença masculina em sua vida, ela passa a se espelhar nas estratégias da amiga para traçar seu "plano de fuga".

Este é o momento da jornada de Hermila em que a sororidade ${ }^{13}$ se apresenta de maneira mais significativa. O termo diz respeito à aliança entre mulheres, baseado no companheirismo e na solidariedade. No feminismo, tem sido utilizado para reforçar as consequências negativas da rivalidade entre mulheres e a necessidade de que elas se unam para alcançarem objetivos em comum. Em sua tese $A$ invenção da sororidade: Sentimentos morais, feminismo e mídia (2019), Tatiane Leal investiga a hipótese de que a sororidade fundamenta uma ética feminista contemporânea, afirmando que

“[...] a sororidade denota um tipo de relação intersubjetiva partilhada apenas entre mulheres, sendo descrita, muitas vezes, como uma espécie de empatia no feminino. Essa afirmação já aponta a afinidade entre os dois conceitos. É como se a sororidade fosse um desdobramento específico da empatia, definida no dicionário Houaiss (2009) como 'capacidade de se identificar com outra pessoa, de sentir o que ela sente, de querer o que ela quer, de apreender do modo como ela apreende etc'." (LEAL, p. 32, 2019)

\footnotetext{
${ }^{13}$ A palavra não existe oficialmente no vocabulário português, mas se origina do latim soror, que significa irmã.
} 


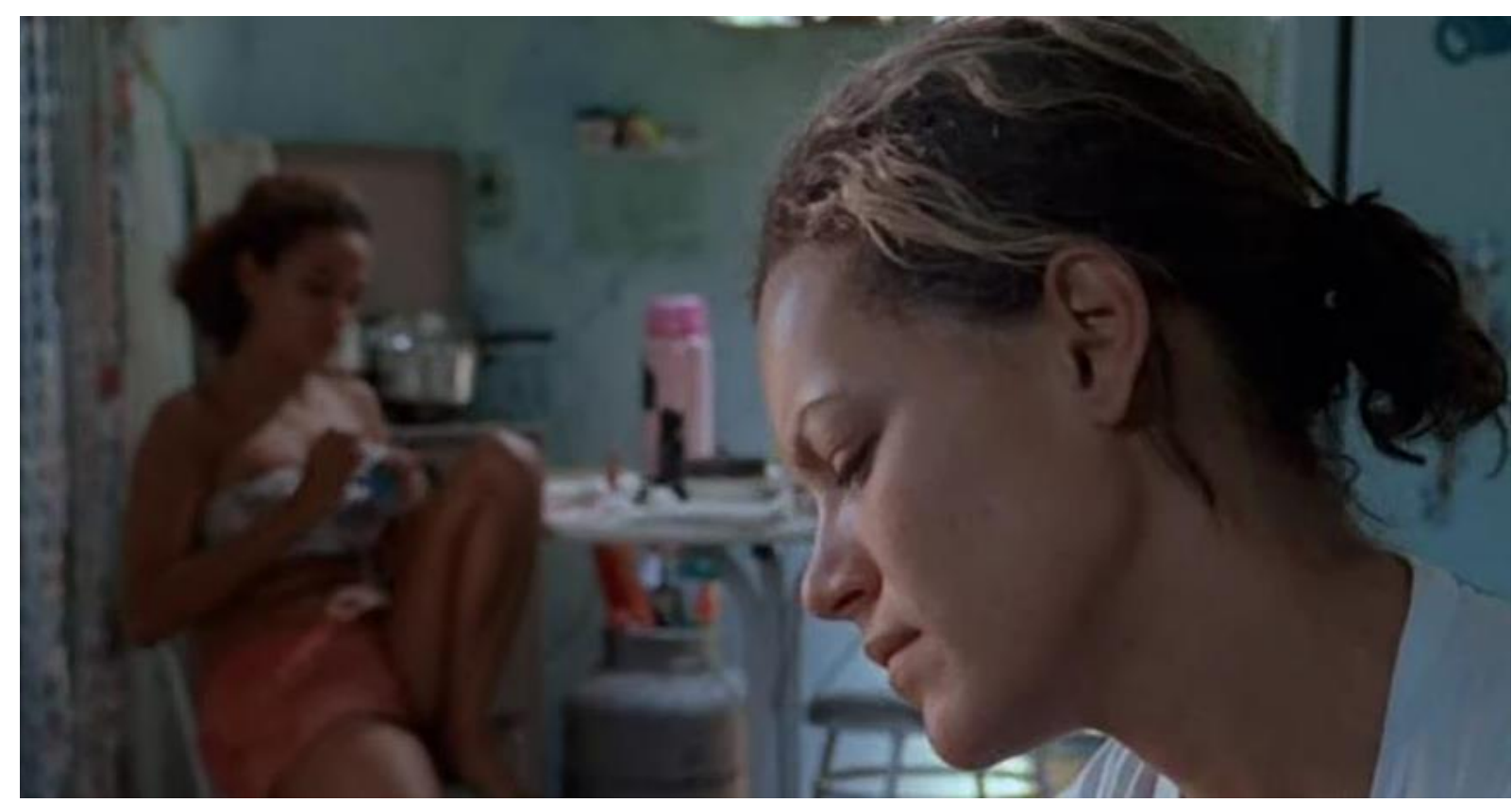

Imagem 28: Georgina se torna uma fonte de inspiração para que Hermila vislumbre possibilidades em sua própria vida. @ VideoFilmes, Celluloid Dreams, Shotgun Pictures.

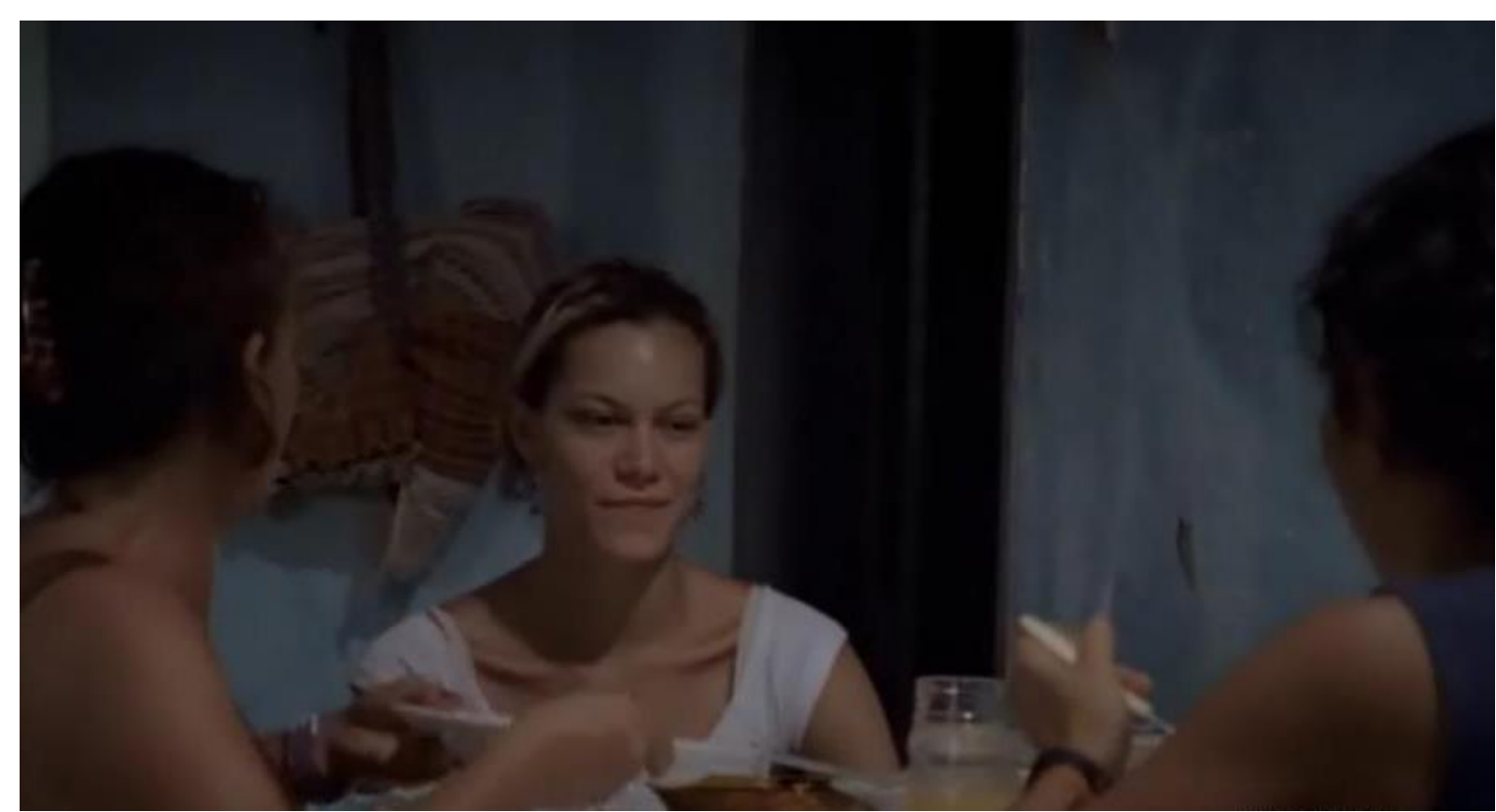

Imagem 29: Mesmo discordando das escolhas de Hermila, a avó e a tia não deixam de ajudá-la a concretizar seus planos. @ VideoFilmes, Celluloid Dreams, Shotgun Pictures.

Ainda que os avanças de Hermila rumo à emancipação pareçam muito tímidos, em uma análise minuciosa de sua jornada, a aliança estabelecida com outras mulheres é inegavelmente um fator que impulsiona seu pequeno processo emancipatório. Enquanto os 
personagens masculinos da história aparecem como elementos que de certa forma impedem o desenvolvimento da protagonista - vide Matheus (o ex) e João (o atual namorado), ambos a usando, de diferentes maneiras -, as personagens femininas (Georgina, Maria e Zezita) formam uma rede de suporte que possibilita a Hermila ir atrás de seus sonhos - mesmo que os meios para alcançá-los, que envolvem rifar seu corpo e comprar uma passagem para qualquer lugar distante de Iguatu, sejam questionáveis.

Embora Hermila encare a desilusão com relação a Matheus como algo ruim, foi a libertação de um amor iludido que a levou a buscar um objetivo para si própria; e foi a ajuda de outras mulheres que a possibilitou concretizar esse objetivo. Talvez o caminho escolhido pela personagem não tenha sido o mais emancipado possível e certamente ela está longe de exercer verdadeiro protagonismo na própria vida - afinal, acaba partindo rumo a um destino incerto, sem condições financeiras que possam garantir, de fato, sua sobrevivência - mas no sacrifício de seu corpo, rifado para um estranho, Hermila vislumbra um futuro transformado.

Por isso a cena final é tão importante em sua jornada, ainda incompleta. Dentro do ônibus, sozinha, a jovem olha pela janela e vê João, em sua moto, colocando-se em seu caminho como se implorasse para que a amada ficasse em Iguatu. O gesto romântico do rapaz joga com as expectativas do público, já que remete aos contos de fadas, nos quais um príncipe encantado apareceria no final, em seu cavalo branco, para resgatar a donzela. A recusa desse resgate se evidencia quando João retorna a Iguatu, sozinho, no plano seguinte. Hermila termina sua jornada diegética não emancipada de muitas amarras, mas minimamente emancipada dessa que seria apenas mais uma dependência masculina. É possível que ela encontre outro homem a quem se apegue de maneira irresponsável na nova cidade, assim como é possível que passe a perceber maior força em si mesma, empoderando-se com a capacidade de decidir sua própria história, sem depender de mais ninguém. 


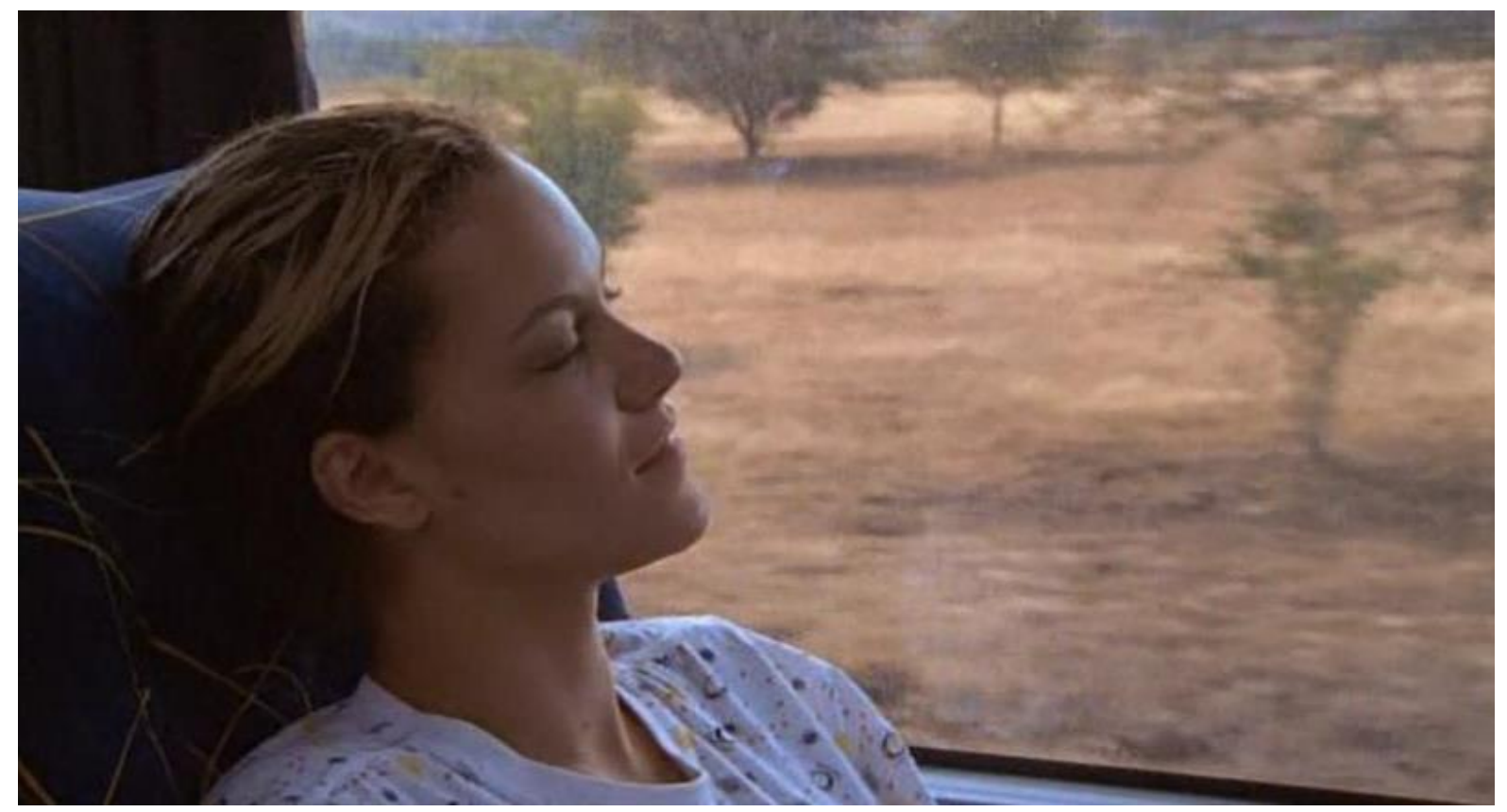

Imagem 30: Mesmo vendo João pela janela, lá fora, Hermila decide continuar sua jornada sozinha. (C) VideoFilmes, Celluloid Dreams, Shotgun Pictures.

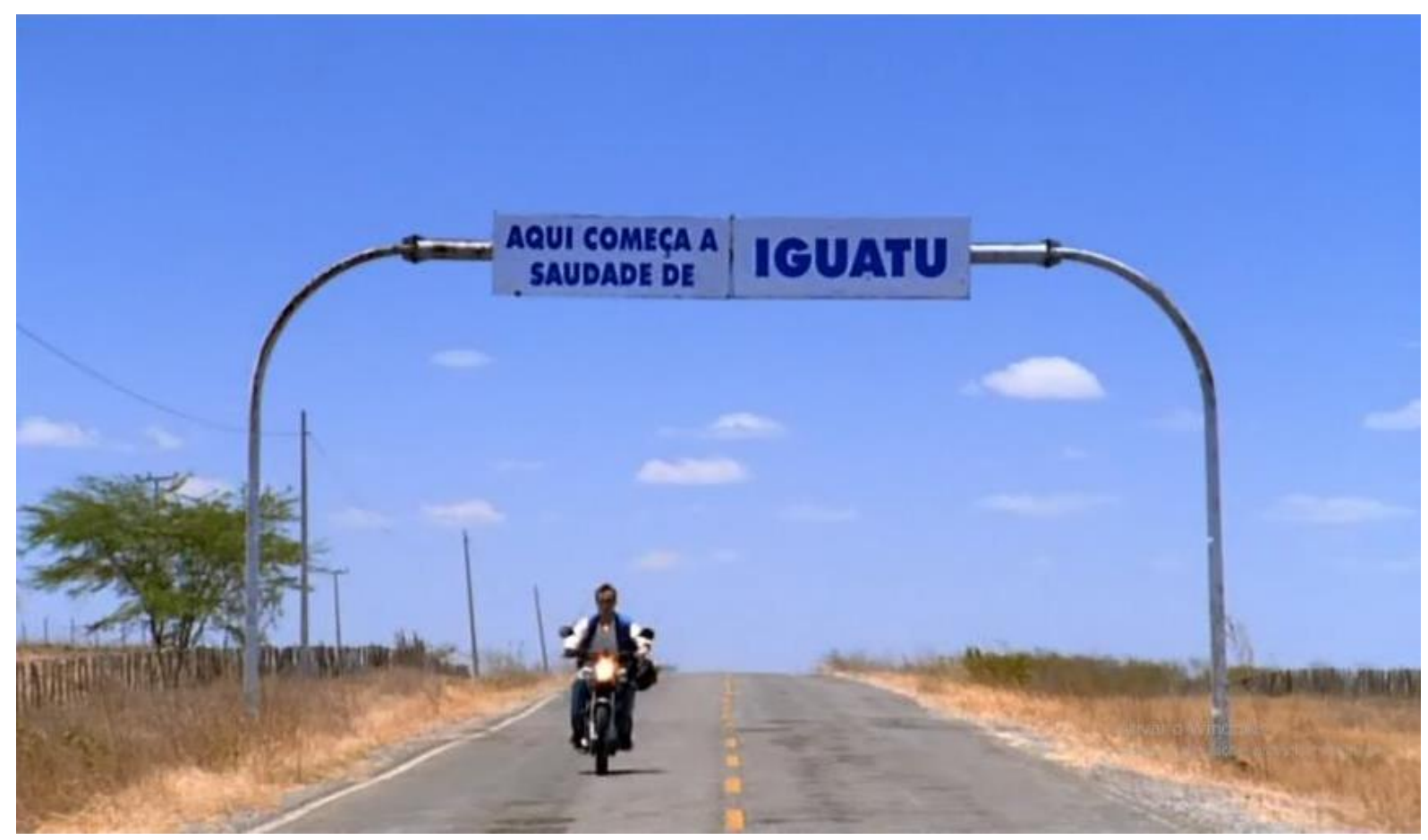

Imagem 31: João retorna sozinho a Iguatu, enquanto Hermila segue seu destino, para longe dali. (C) VideoFilmes, Celluloid Dreams, Shotgun Pictures. 
Assim como Hermila, que retorna à sua cidade natal na cena inicial de O Céu de Suely, a personagem Val, de Que Horas Ela Volta? ${ }^{14}$, começa sua jornada com um resgate de suas origens. Enquanto cuida do filho da patroa e o incentiva a aprender a nadar, ela conversa ao telefone com a própria filha, que inicialmente se recusa a falar com Val. Não é possível ouvir os dois lados da conversa, mas torna-se evidente que a menina guarda ressentimentos no que concerne à mãe. No entanto, a escolha entre o trabalho e a família não é realmente uma escolha para Val, já que ela não acredita que deve retornar para o Nordeste como Jéssica gostaria. Vista de costas para a câmera, a protagonista denota uma desconexão com o espectador que é reflexo de suas próprias relações familiares, claramente abaladas pela distância.

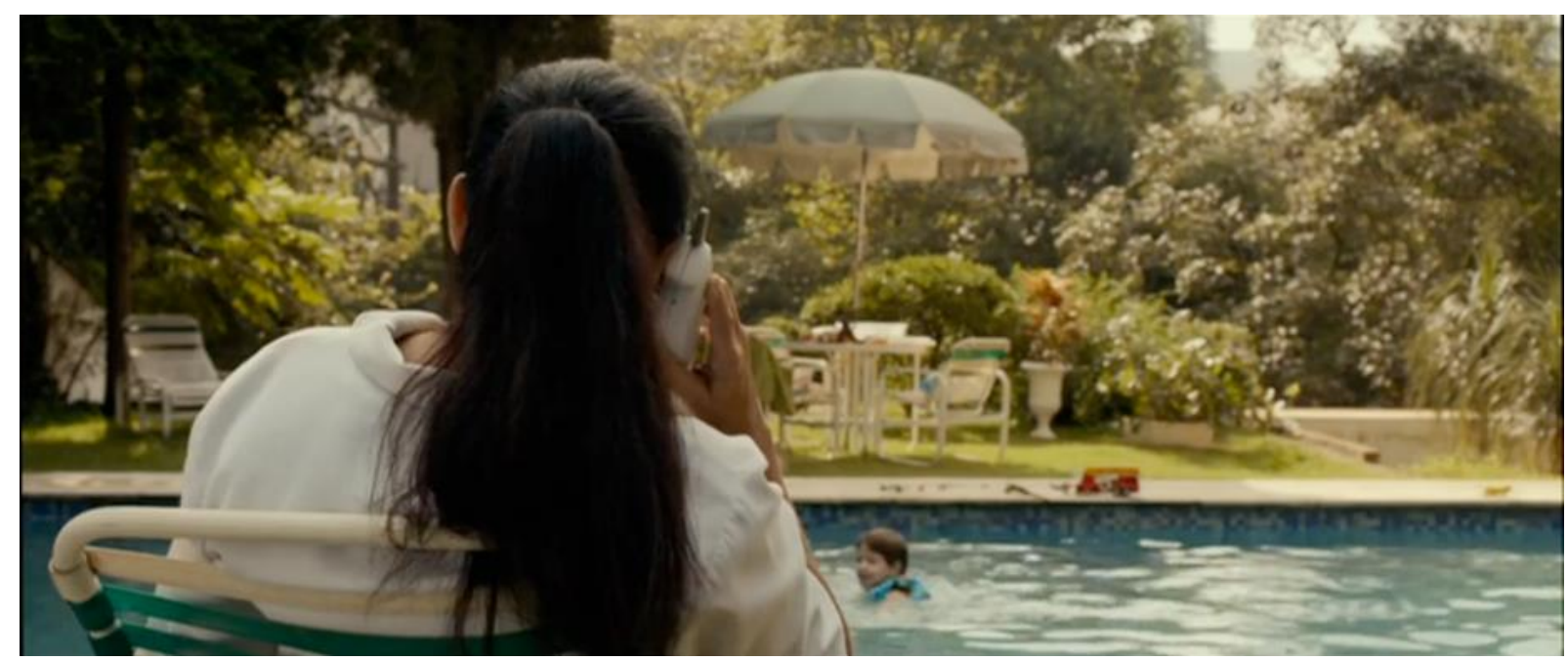

Imagem 32: Um dos enquadramentos iniciais de Que Horas Ela Volta? (Anna Muylaert, 2015), posiciona a protagonista de costas para a câmera. (C) Globo Filmes, Gullane Filmes, África Filmes, Pandora Filmes.

Há uma elipse temporal com relação à primeira cena e a personagem aparece descendo as escadas da casa onde ainda trabalha, tomando todos os cuidados para não acordar de maneira abrupta o filho de sua patroa, Fabinho - agora um adolescente. A relação de

14 Não por acaso, o filme recebeu o título em inglês de The Second Mother, ou seja, "A Segunda Mãe", referindo-se ao fato de que a empregada possui uma relação materna mais intensa com Fabinho do que a própria mãe dele. Essa denominação também carrega em seu significado o papel de coadjuvante exercido por Val na casa. Para ela é delegado todo o trabalho de uma mãe, porém pouco ou nenhum reconhecimento. 
intimidade entre Val e o rapaz, cultivada durante vários anos, é expressada visualmente na proximidade física dos dois e narrativamente por meio do diálogo em que ele relata à empregada suas decepções amorosas - como faria com uma amiga ou com a própria mãe, se o relacionamento entre os dois permitisse tal abertura.

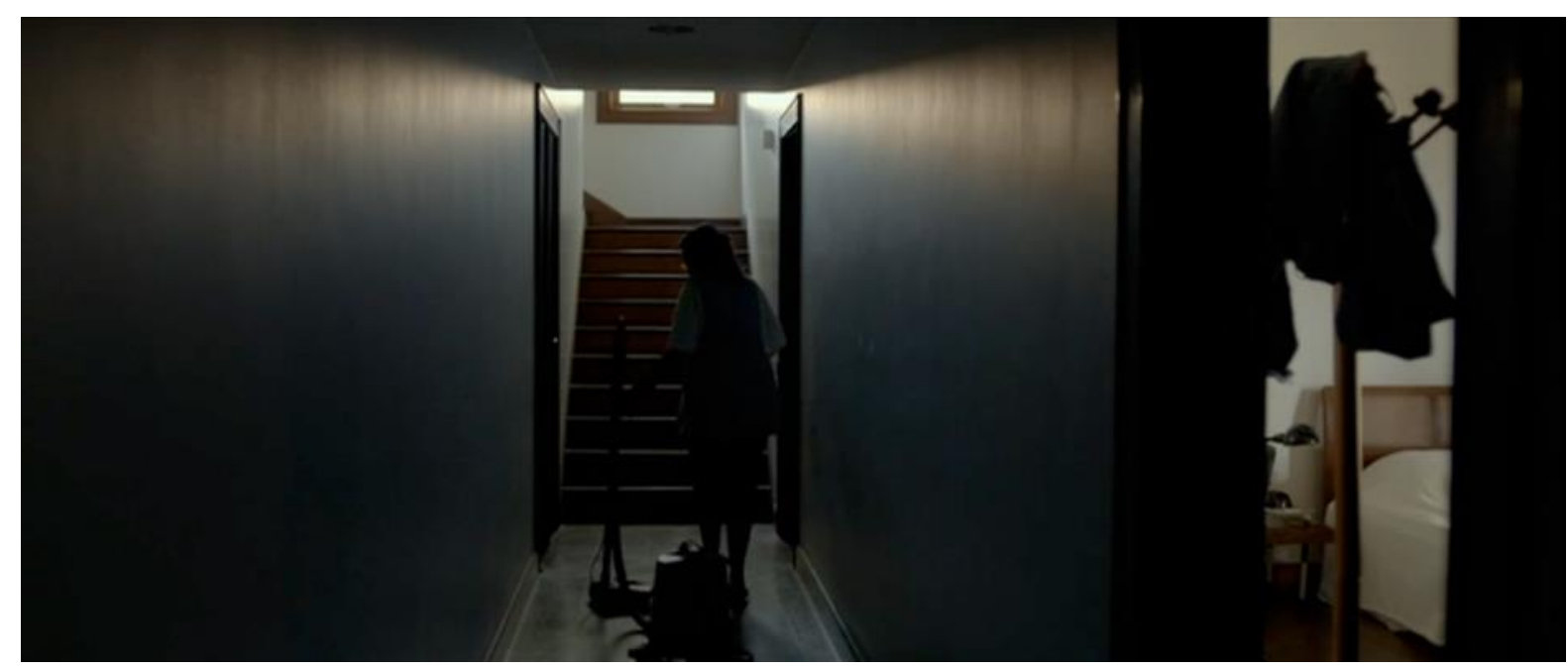

Imagem 33: Apesar da intimidade com Fabinho, a função de Val na casa é bem determinada. @ Globo Filmes, Gullane Filmes, África Filmes, Pandora Filmes.

Apesar dessa relação de visível afeto, os planos seguintes, em que a funcionária aparece limpando diversos espaços, sempre cuidando para não atrapalhar a rotina da família, constantemente na obscuridade, deixam claro o principal papel de Val na casa: trabalhar. De maneira semelhante a Hermila, sua condição financeira e falta de capacitação profissional impõem a ela uma situação de dependência dos patrões e não-protagonismo em sua própria história. O abismo ela e os "senhores da casa" é demonstrado por diversos enquadramentos, nos quais Bárbara e Carlos são posicionados ao fundo do quadro, recortados pela porta da cozinha, enquanto a funcionária executa as tarefas domésticas e atende às ordens de ambos. Essa é a visão que a empregada tem da família para a qual trabalha, um verdadeiro recorte de classes, denotando uma relação marcada pela lógica da hierarquização, advinda de uma herança colonialista que desumaniza e segrega o trabalhador.

Conforme aponta Mariana Souto: 
"Que horas ela volta? busca a perspectiva de Val ao fincar sua câmera da cozinha para a sala, fitando os donos da casa de maneira parcialmente oculta, distante, entrecortada pelo vão da porta e por outros objetos. Enquadramento semelhante é visto rapidamente em Casa Grande, mas da sala para a cozinha, reforçando a perspectiva patronal. A visão do empregado ao longe, com objetos postos entre a câmera e o personagem, acentuando-se assim a distância, é algo predominante também em Santiago." (SOUTO, 2018, p. 18-19)

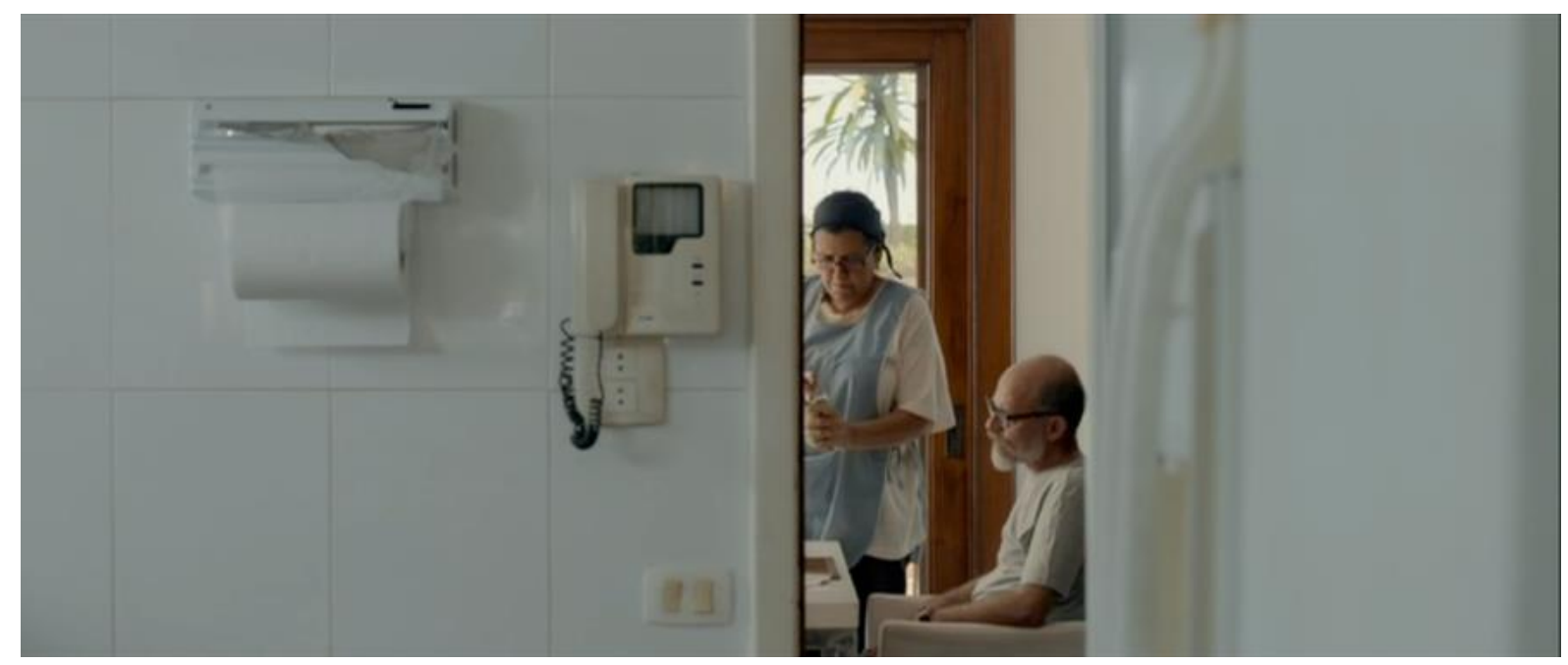

Imagem 34: A mesa de jantar é mostrada do ponto de vista da cozinha, em Que Horas Ela Volta?. (C) Globo Filmes, Gullane Filmes, África Filmes, Pandora Filmes.

A maneira como a personagem é apresentada no início do filme mostra o quanto ela ainda está distante da emancipação. Seu apego ao personagem Fabinho é um indicador de que a dependência não somente financeira, como emocional, da família que a contratou se tornaram parte de quem ela é. O rapaz, quando confrontado pela própria mãe, busca refúgio no pequeno quarto da empregada. Ao contrário da figura materna essencialmente repressiva representada por Bárbara, a empregada toma para si o papel de não apenas aceitar as falhas do garoto sem julgá-lo, mas de oferecer o conforto dos braços de uma mãe que não conseguiu demonstrar para com a própria filha esse mesmo afeto. 


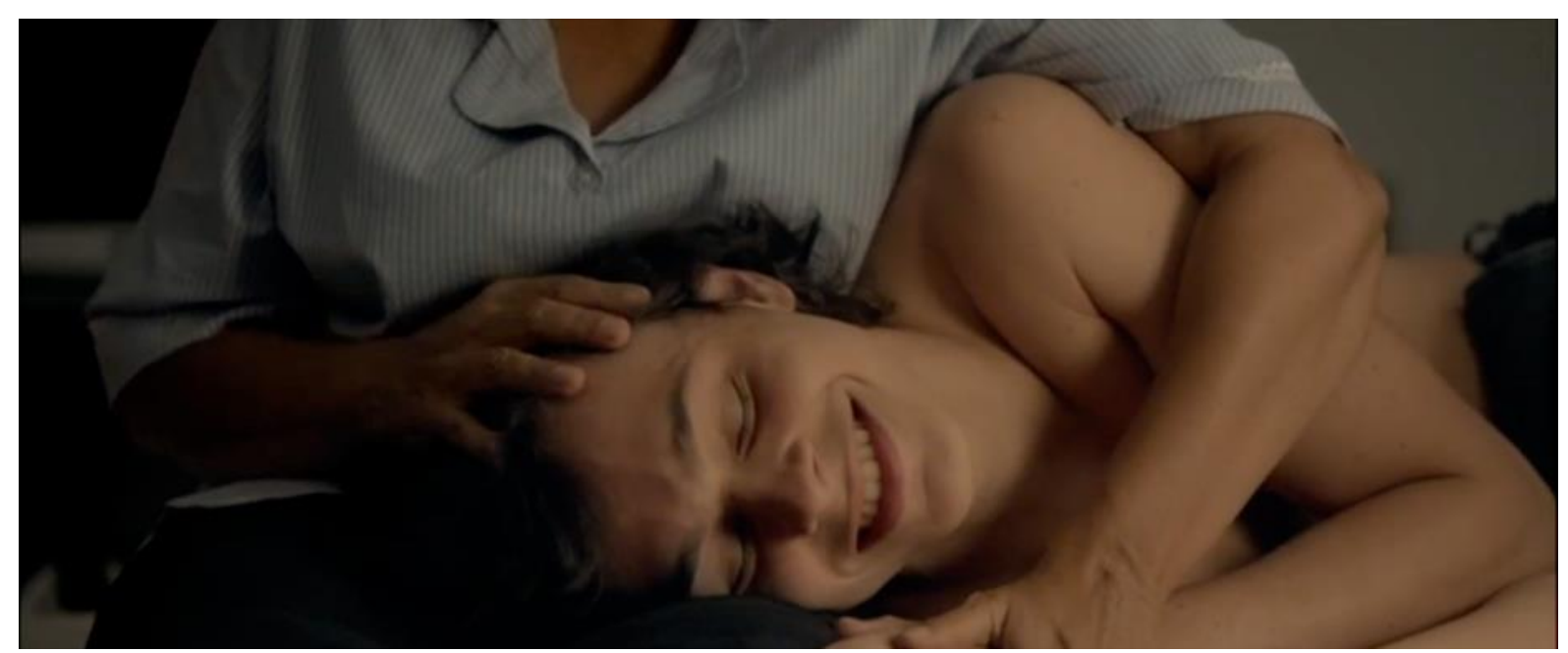

Imagem 35: A relação entre Val e o filho da patroa, Fabinho, é de proximidade física e afeto. C Globo Filmes, Gullane Filmes, África Filmes, Pandora Filmes.

O enquadramento que corta a cabeça da protagonista, na cena retratada na Imagem 35, ilustra a maneira como ela colocou em segundo plano suas necessidades pessoais, de certa forma excluindo-se da equação e reduzindo a importância de suas demandas particulares. Os dramas e vontades de Fabinho estão em primeiro plano, no centro de tudo - ao menos dentro da dinâmica familiar da casa em que vivem. Val, por sua vez, é posicionada no lar dessa família como mera coadjuvante da narrativa; muitas vezes, em clara posição de inferioridade perante os patrões.

A personagem somente começa a questionar essa dinâmica quando recebe um importante telefonema de Jéssica. A comunicação se inicia confusa, fragmentada. Val se encontra no escuro, em seu quarto, e a luz está no criado-mudo, no canto do quadro, onde fotos de Jéssica demonstram que a mãe buscou manter lembranças dessa relação interrompida. No entanto, o ruído da televisão, ao fundo, assim como o sinal ruim do aparelho celular, são elementos que evidenciam a distância e a desconexão entre as duas personagens. A surpresa na voz de Val e seu posterior sorriso no rosto são as reações de uma mãe ausente perante a notícia de que a filha pretende ir ao seu encontro, viajando do Nordeste para São Paulo, com o objetivo de prestar vestibular. 
A tomada de consciência de Val começa a se desenvolver na cena em que ela tenta conversar com a patroa a respeito da chegada da filha, mas é interrompida por uma série de perguntas e ordens relacionadas às tarefas domésticas. Sem conseguir estabelecer qualquer comunicação a respeito de suas demandas pessoais, Val ainda está em um momento de sua narrativa no qual apenas observa a vida de fora, como se não tivesse possibilidade de participar ou tomar decisões importantes. Porém, essa situação de obscuridade e de nãoprotagonismo está prestes a mudar para a personagem.

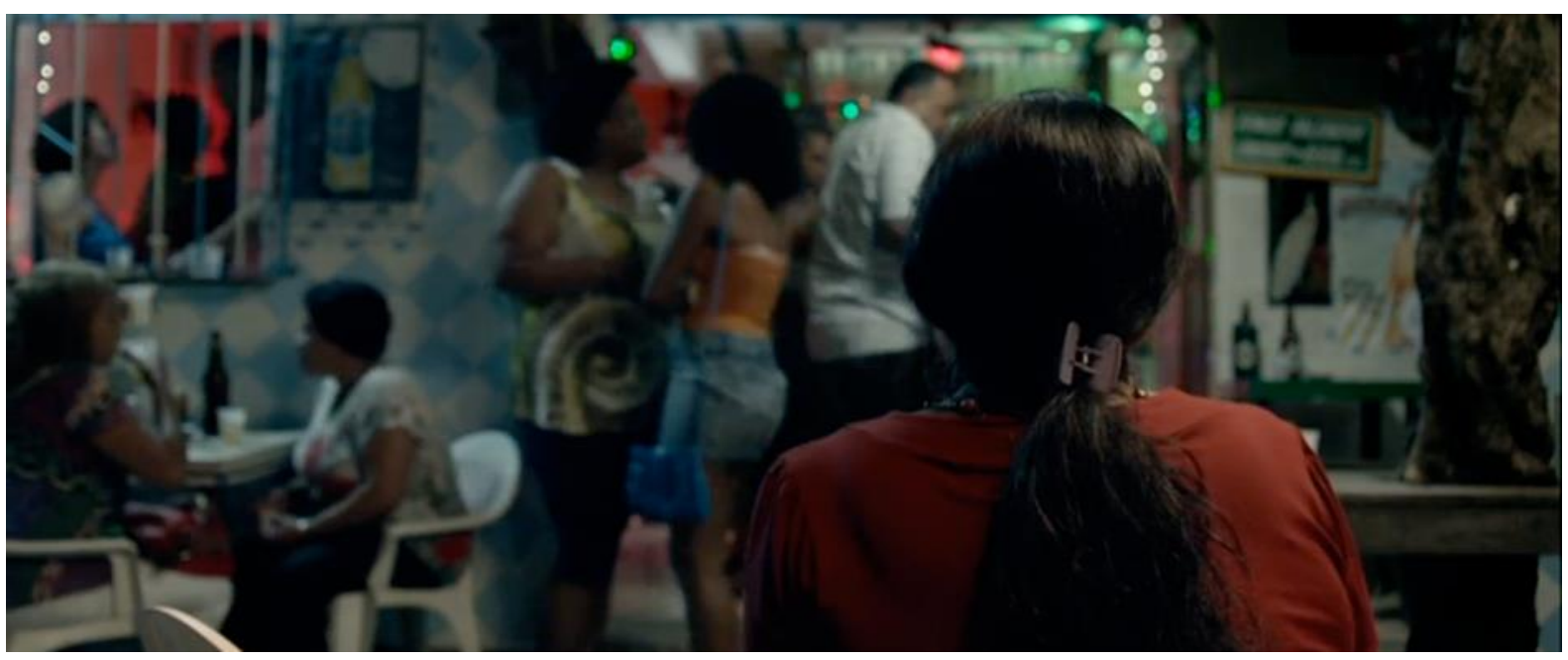

Imagem 36: Novamente enquadrada de costas, Val observa o movimento em um bar. (C Globo Filmes, Gullane Filmes, África Filmes, Pandora Filmes.

Eventualmente, Val consegue contar para Bárbara sobre os planos de receber a filha em seu quarto. "Você é praticamente da família", afirma a patroa, tranquilizando a empregada. A pretensa familiaridade desaparece quando Bárbara pergunta se Val está procurando um lugar para as duas ficarem, um "cantinho para alugar". Outro momento de queda da "máscara de cordialidade" acontece na cena seguinte, quando a funcionária é repreendida por usar, em uma festa para convidados na casa dos patrões, o jogo de xícaras que ela ingenuamente deu de presente para Bárbara. O próprio figurino de Val na cena, um tradicional uniforme de empregada (figurino muito comum em novelas da televisão aberta, utilizado como elemento visual para denotar as diferentes hierarquias sociais), que contrasta 
com as roupas sofisticadas da senhora da casa, tem o objetivo de colocar a serviçal "em seu lugar”. Se ela compreende o abismo que a separa dessas pessoas, é impossível determinar, mas nesse ponto da narrativa o espectador já pode concluir que sua dinâmica de convivência naquela casa parte de uma posição essencialmente subjugada e invisibilizada - posição essa que será abertamente questionada pela filha Jéssica.

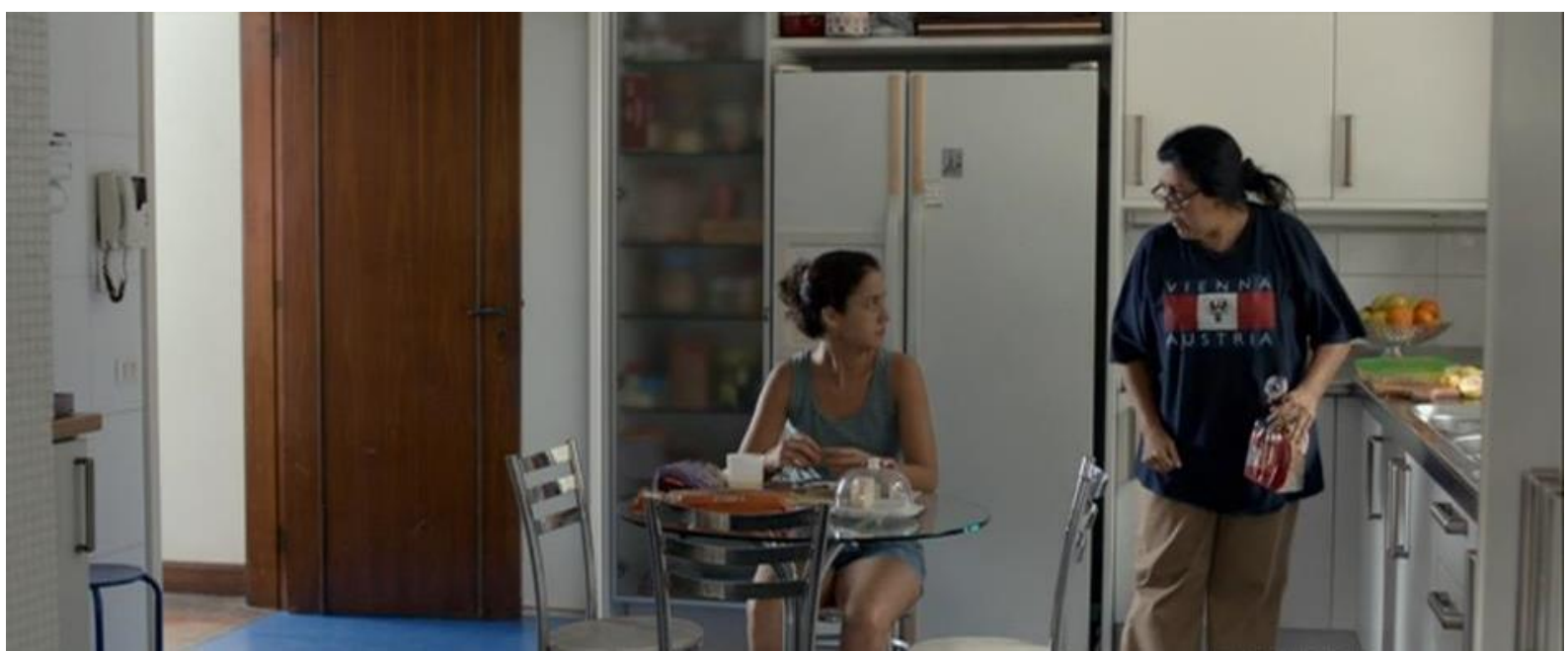

Imagem 37: Com sua visão de mundo progressiva, Jéssica questiona a posição de inferioridade de Val na casa. (C) Globo Filmes, Gullane Filmes, África Filmes, Pandora Filmes.

Mais uma vez, a sororidade tem papel essencial no desenvolvimento do protagonismo. É a relação com a filha que impele Val a buscar sua emancipação, vislumbrando novas possibilidades de viver e pela primeira vez colocando as próprias necessidades acima das dos patrões. Jéssica simplesmente não se permite ser colocada em uma posição de inferioridade; pelo contrário, quando lhe oferecem o quarto de hóspedes, ela aceita como se fosse normal a filha da empregada ocupar as melhores acomodações da casa dos patrões. Seu comportamento, considerado por Bárbara - e pela própria Val - como abusado e irreverente, é uma forma que a jovem encontra de normalizar o fato de estar tomando conta de um ambiente que tecnicamente não lhe pertenceria. O próprio posicionamento da jovem em cena difere muito daquele em que a mãe se encontra: na mise-en-scène, Jéssica não hesita em ocupar os espaços que seriam pertencentes a outra classe. Sua posição é de altivez e enfrentamento. 
É justamente quando os questionamentos da filha começam a incomodar Val que o progresso em sua jornada rumo à emancipação se manifesta. Para Jéssica, é inconcebível que a mãe seja feliz vivendo em um quartinho reduzido, reservando suas interações à área de serviço, sem poder sequer colocar os pés na piscina dessa família que alega tê-la acolhido tão calorosamente. Por isso a moça pede para ir embora da casa e, quando não consegue se mudar de imediato para o local que ela e a mãe pretendiam alugar, sendo obrigada a retornar para onde estava, indaga a Val como ela consegue ser tratada desse jeito, como "uma cidadã de segunda classe".

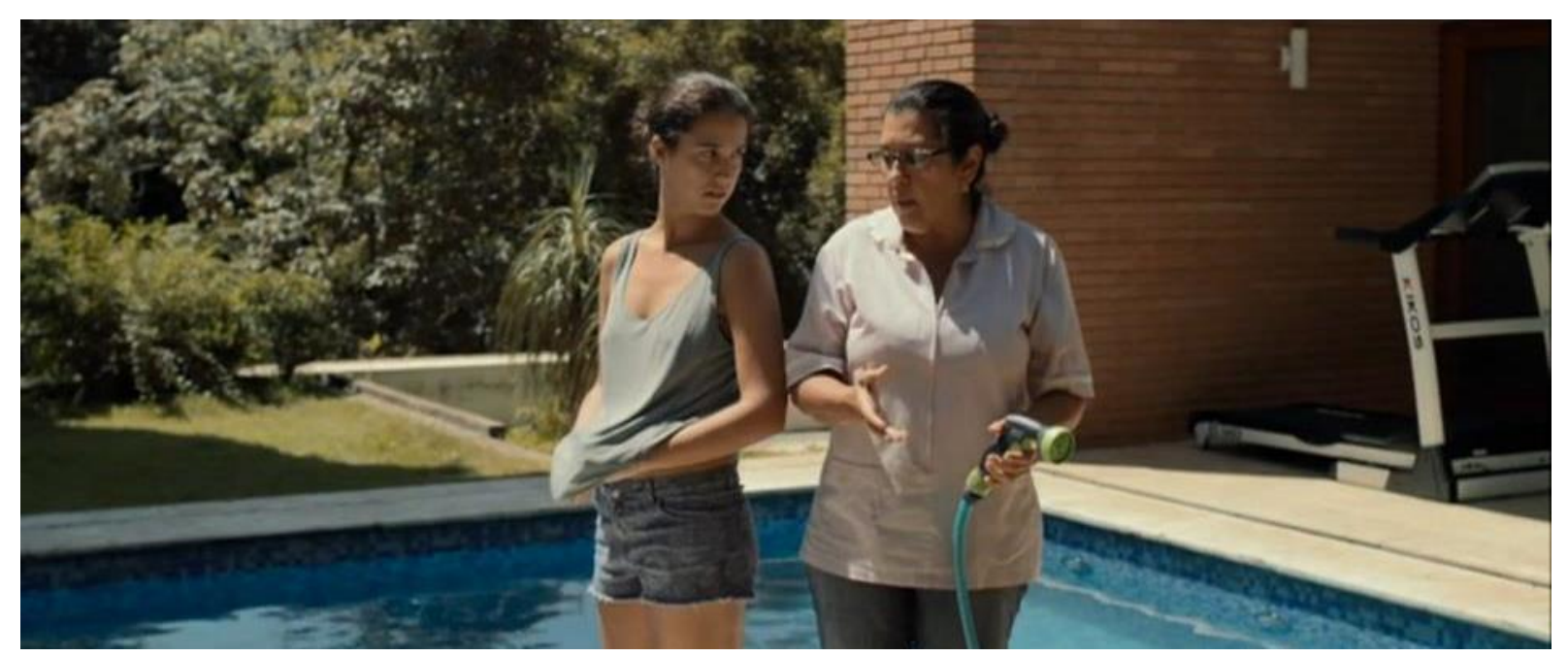

Imagem 38: Jéssica não concorda com as atitudes de submissão da mãe, perante os patrões. @ Globo Filmes, Gullane Filmes, África Filmes, Pandora Filmes.

A revolta crescente de Jéssica com relação à situação se justifica pelo fato de que, mesmo após questionar inúmeras vezes a maneira como Val se coloca frente aos patrões, a mãe continua defendendo a família de Bárbara e elaborando argumentos para não mudar seu modo de vida. Mesmo quando ouve da boca da patroa que sua filha deve permanecer "da porta da cozinha para lá”, ela abaixa a cabeça e aceita a ordem. Essa atitude apenas demonstra o quanto é difícil sair de uma "zona de conforto" autoimposta, dentro do "mundo comum" (CAMPBELL, 1949), e enfrentar os sacrifícios que a emancipação verdadeira requer. Felizmente, para Val, a filha não se dobra ao senso comum e permanece firme em suas 
convicções - tanto que acaba realmente indo embora da casa. Na cena em que isso acontece, a chuva torrencial, que não impede a partida de Jéssica, age como um elemento narrativo no sentido de "lavar a alma" da jovem, que se sentia pesada por ter que aceitar tantas atitudes consideradas por ela absurdas e elitistas. Também representa o fato de que os enfrentamentos da vida podem parecer desconfortáveis e exigir sacrifícios, até mesmo causar sofrimento, mas em última análise são necessários e até bem vindos.

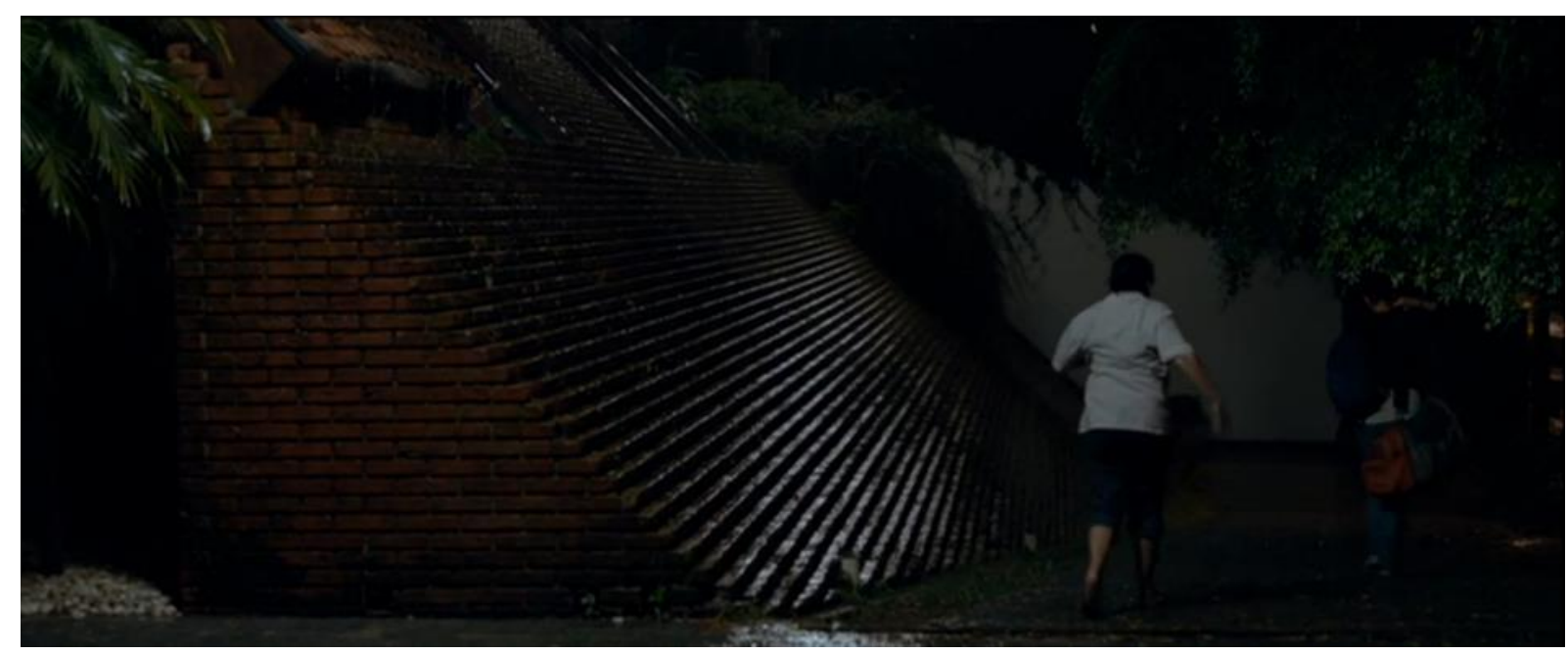

Imagem 39: Cansada do tratamento recebido dos patrões de Val, Jéssica vai embora. ㄷ Globo Filmes, Gullane Filmes, África Filmes, Pandora Filmes.

Conforme escreve Maureen Murdock, quando uma mulher se liberta de uma identidade ligada ao patriarcado, ela sente uma necessidade de se reconectar com o feminino. "Há um desejo de desenvolver aquelas partes de si mesma que ficaram enterradas na jornada heroica: seu corpo, suas emoções, seu espírito, sua sabedoria criativa.” (MURDOCK, p. 111, 1990). Na personagem Jéssica, o desenvolvimento dessa natureza emancipada é evidente. Em Val, a transformação interna firma raízes quando a protagonista descobre que, apesar de todas os obstáculos e limitações sociais, a filha foi capaz de passar no concorrido vestibular para o curso de arquitetura; ao contrário do privilegiado Fabinho, que falhou na tarefa e, mesmo diante do fracasso, ainda foi "recompensado" com um intercâmbio no exterior. 
Ao final de sua jornada diegética, quando se muda com a filha para um pequeno apartamento na periferia, Val finalmente descobre que Jéssica teve um filho e as duas conversam francamente sobre os respectivos sofrimentos: uma, sentindo-se abandonada e esperando a mãe retornar; a outra, presa a uma vida da qual não conseguia mais se libertar. Essa conversa e suas implicações - assim como a partida de Fabinho para o exterior - são elementos cruciais para que Val decida pedir sua demissão do emprego, decisão essa que é recebida com surpresa por Bárbara. Questionada sobre os motivos, Val encontra dificuldade de expressar em palavras, mas deixa claro que não se trata de uma questão de dinheiro: "Isso é eu mesma”, ela repete à patroa. Essa incapacidade de traduzir seu próprio desenvolvimento interno é compreensível, já que Val se sente mal por deixar para trás o que considerou como lar, durante tantos anos. Mas a conexão com Jéssica é mais forte do que tudo, por isso ela declara: "Eu acho que eu estou precisando ficar com minha filha, cuidar de minha filha."

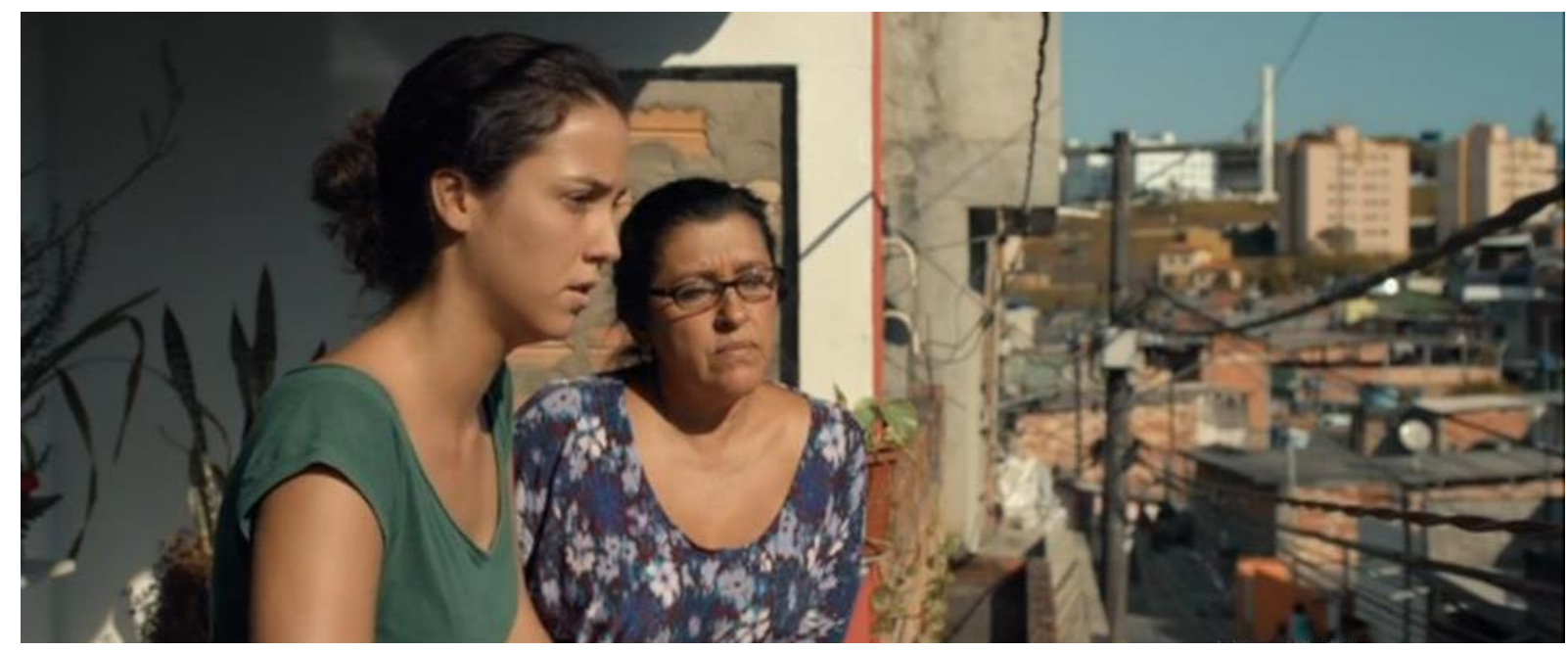

Imagem 40: Em sua nova casa, Jéssica e Val conversam sobre os erros do passado. (C) Globo Filmes, Gullane Filmes, África Filmes, Pandora Filmes.

De fato, Val continuará vivendo uma vida humilde e com limitações financeiras; porém, dentro da própria casa e segundo suas próprias regras, podendo vivenciar plenamente seu papel de mãe e avó. O alívio pela conclusão desse processo emancipatório é visível na última cena do filme, em que se torna evidente o quanto seu pedido de demissão representou 
para ela, como aprendizado. Enquanto arruma o conjunto de café (que havia dado de presente para Bárbara) na mesa do pequeno apartamento que agora divide com Jéssica, Val começa a traçar planos para um futuro em que finalmente será protagonista de sua vida: fazer um curso de massagem e trazer o neto para viver com elas. Sua evolução pessoal não está de forma alguma concluído, mas indubitavelmente, entre as três mulheres estudadas na presente pesquisa, ela é a personagem que mais avançou no sentido de conquistar autonomia e autorrealização. Esse avanço pode ser percebido na maneira como a linguagem corporal entre Val e sua filha mudou, no decorrer do filme: ao final, elas se mostram verdadeiramente conectadas - sorriem, olham-se nos olhos e seguram as mãos uma da outra.

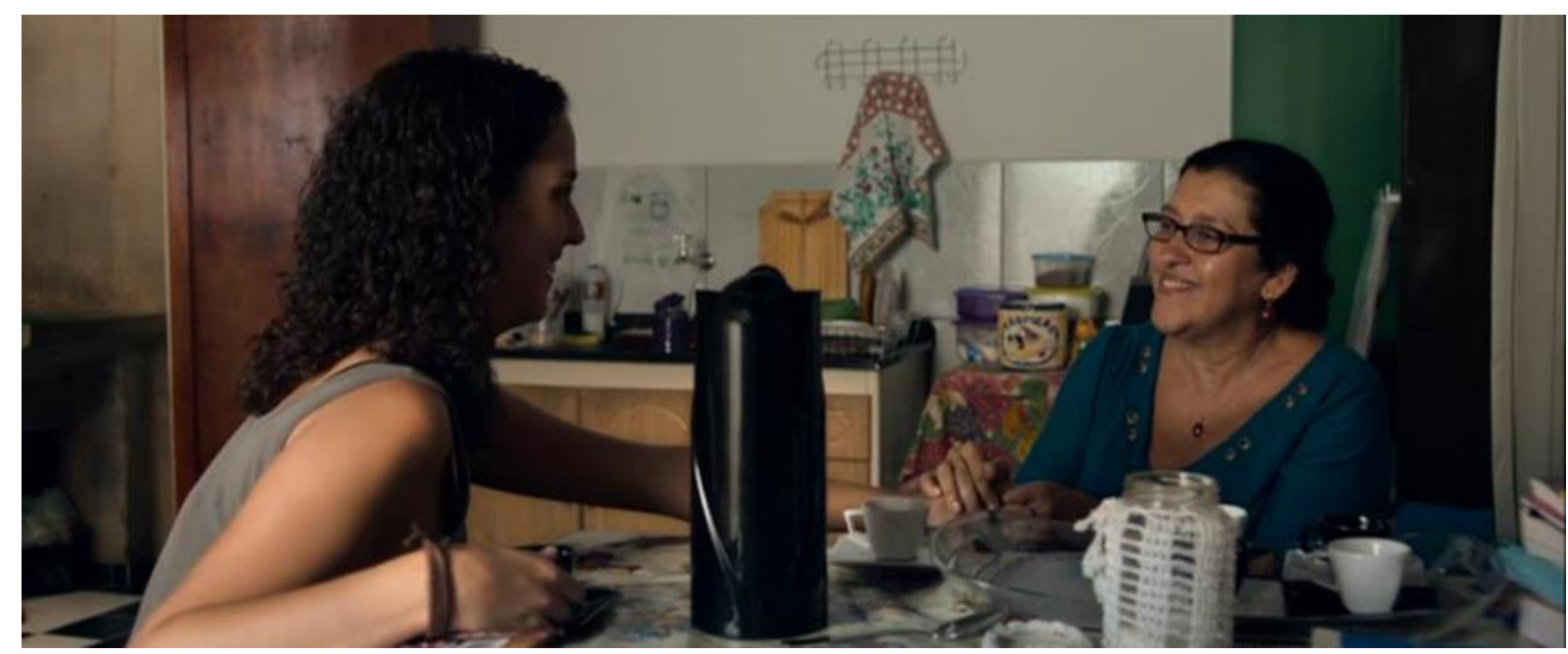

Imagem 41: Em um momento de intimidade com a filha, Val faz planos para o futuro. @ Globo Filmes, Gullane Filmes, África Filmes, Pandora Filmes.

Contudo, nem sempre a jornada das heroínas rumo à emancipação se completa. Do mesmo modo que Hermila e Val, a Rosália de Pela Janela é apresentada em sua história como uma protagonista sem protagonismo, já que não possui muitas chances de escapar ao destino que lhe é imposto, na condição de mulher pobre e trabalhadora, presa em uma rotina que a limita a uma existência sem perspectivas. A primeira imagem da personagem a mostra através de um reflexo na água, de ponta-cabeça. A opção estética pelo uso de elementos reflexivos, no decorrer do filme - tais como espelhos, superfícies de vidro e poças d'água - tem relação 
direta com a maneira como a própria Rosália encara a si mesma: sob uma visão incompleta e distorcida, sem poder enxergar de forma exata e clara quem ela é realmente.

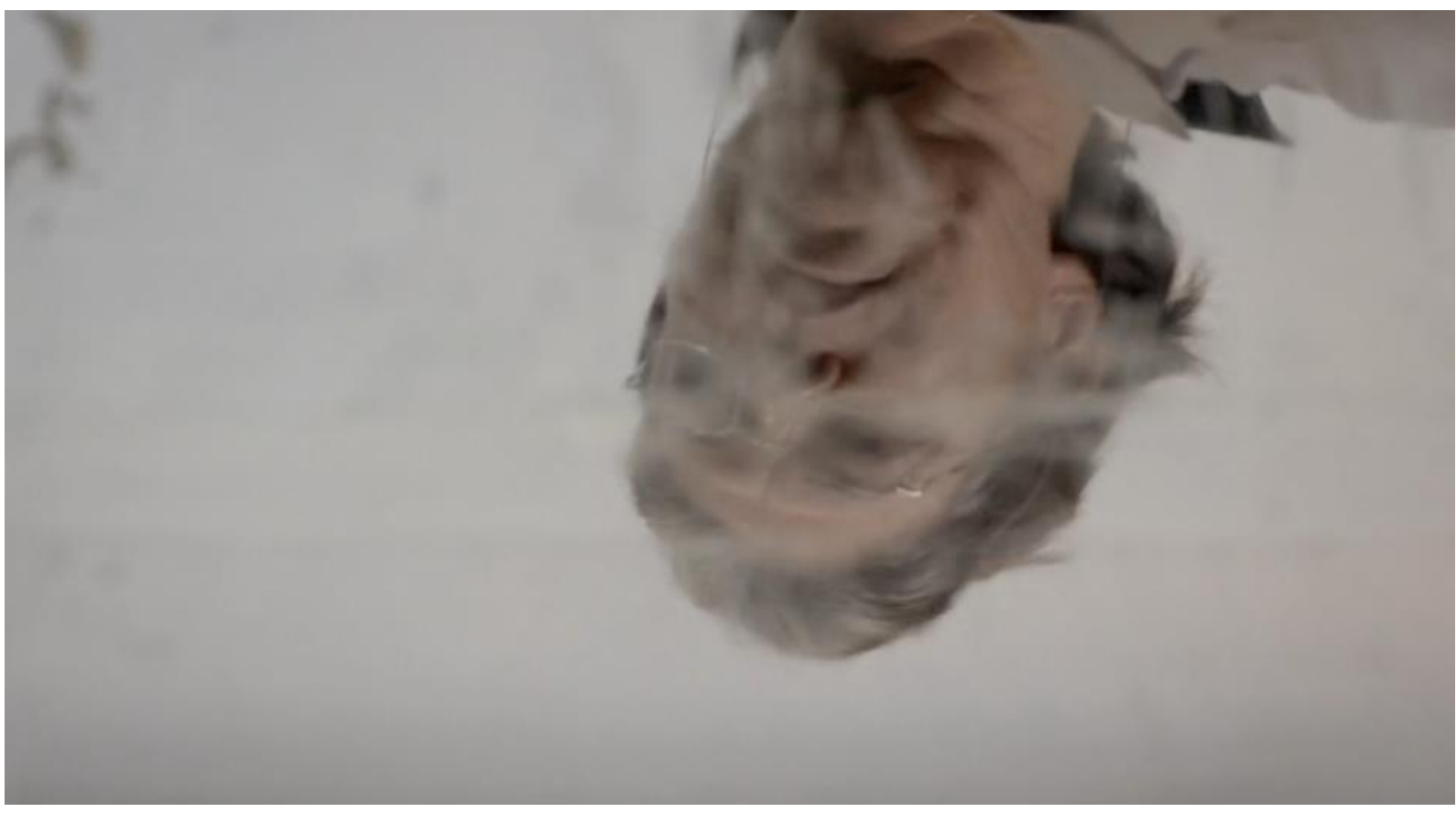

Imagem 42: A personagem Rosália, de Pela Janela (Caroline Leone, 2017), é constantemente vista através de reflexos. (C) Vitrine Filmes.

Rosália executa uma série de tarefas manuais e repetitivas em seu dia a dia de trabalho. Ela é definida, sobretudo, por sua função como operária, não como ser humano com desejos e ambições particulares. Uma mulher prática, objetiva e de poucas palavras, que exerce suas tarefas sem questionar ou interagir com os outros além do estritamente necessário, ela é retratada como objeto de um sistema limitante - no sentido de atuar como máquina laboral, cuja individualidade não possui relevância para os empregadores. A personagem manifesta a aceitação de seu destino por meio do silêncio e do cumprimento meticuloso de suas atividades.

A ação de abrir janelas é um gesto que Rosália realiza diversas vezes no decorrer do filme, como representação visual de sua relação com o mundo. Lá fora, a vida acontece e há luminosidade, possibilidades. A personagem observa de dentro, como que encarcerada em sua 
realidade. Exceto pelos instantes em que está cantando, enquanto prepara o café, as ações dela são automáticas, como que desprovidas de significado. Seu canto ocasional se contrapõe à inexistência de cenas com qualquer trilha musical não diegética no filme - as canções são breves momentos de "respiro" em meio a uma rotina mecânica. Nesse ponto da jornada, Rosália é a personagem que mais se aproxima do herói de Campbell:

"Aprisionado pelo tédio, pelo trabalho duro ou pela 'cultura', o sujeito perde o poder da ação afirmativa dotada de significado e se transforma numa vítima a ser salva. Seu mundo florescente torna-se um deserto cheio de pedras e sua vida dá uma impressão de falta de sentido.” (CAMPBELL, 1949)

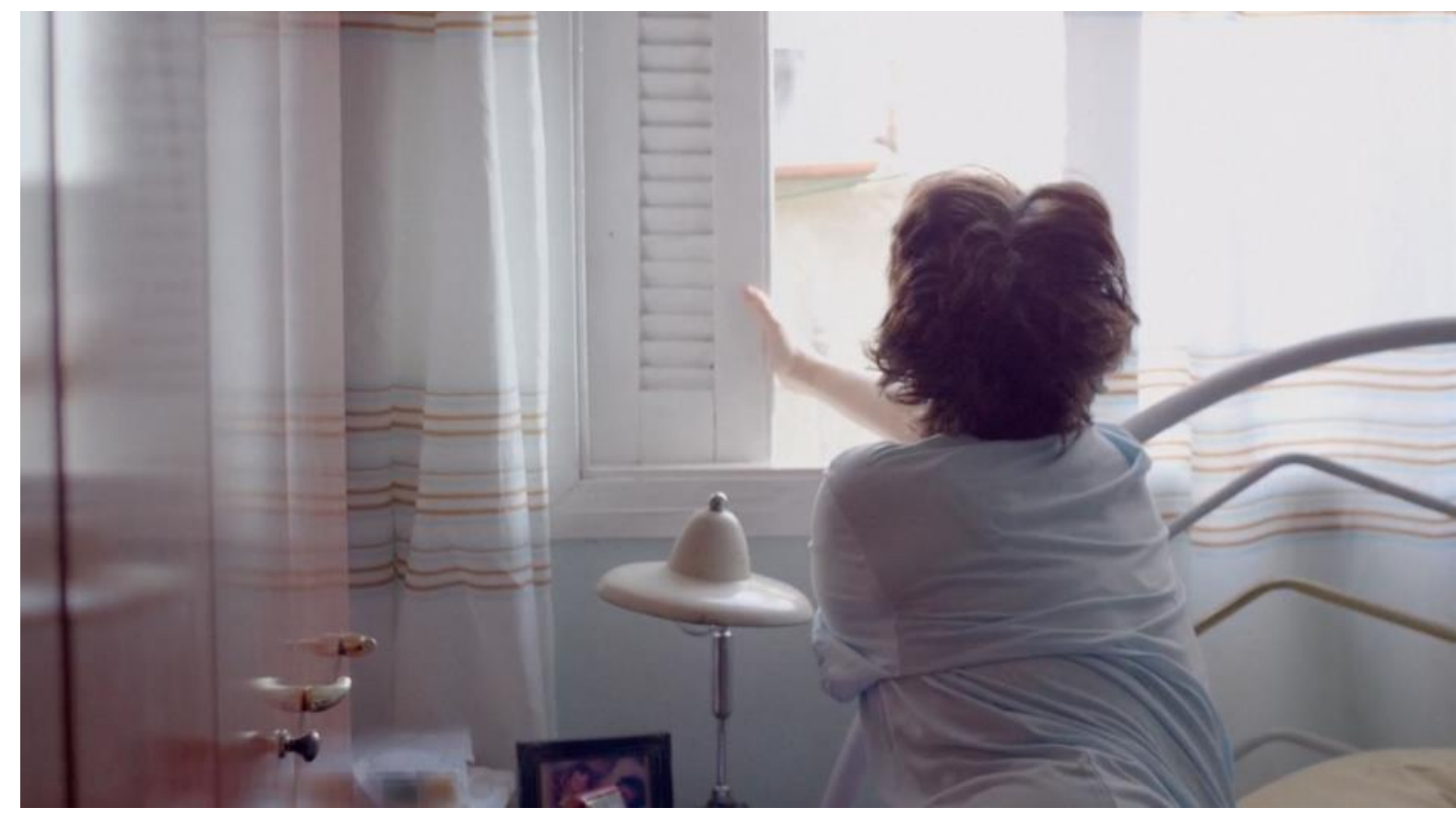

Imagem 43: Em diversos momentos de Pela Janela, a personagem Rosália aparece abrindo janelas. (C) Vitrine Filmes.

Tanto as atitudes de Rosália quanto as de Hermila remetem a aspectos da personagem Jeanne Dielman (Delphine Seyrig), no longa-metragem Jeanne Dielman, 23, Quai du Commerce, 1080 Bruxelles (1975), da cineasta belga Chantal Akerman. Mãe viúva de um filho adolescente, Jeanne leva uma existência repetitiva e desestimulante em um pequeno 
apartamento em Bruxelas, tendo seus dias divididos entre as tarefas domésticas e o trabalho como prostituta ocasional. Entre as semelhanças que aproximam as obras, estão o uso do tempo como ferramenta para potencializar as sensações, que vão da resignação ao colapso, além de temáticas relacionadas ao corpus desta pesquisa - como a solidão e a falta de perspectivas. No longa-metragem de Chantal Akerman, a personagem também executa suas tarefas domésticas de forma eficiente e solitária, limitando sua existência a uma dinâmica familiar de interações superficiais, porém existe nela uma fagulha desafiadora, manifestada por meio da sexualidade de seu "trabalho informal". Embora trágico, o final do filme, em que Jeanne assassina um de seus clientes, demonstra algum tipo de reação, uma espécie de fuga de sua realidade mecânica e opressiva. Tal dimensão não existe no universo de Rosália, fechado a qualquer possibilidade de transformação no que diz respeito à sua falta de emancipação em qualquer aspecto.

Companheiro de Rosália na velhice, seu irmão José parece ser o único contato verdadeiramente humano que a personagem se permite estabelecer. No trabalho, ela almoça sozinha, enquanto continua realizando tarefas. Em casa, também tem seus momentos de solidão, mas sem descanso algum dos serviços domésticos - os poucos instantes de lazer a que se permite, a personagem passa bordando. Sua existência é completamente definida pelo trabalho, por isso ela vê a demissão do emprego na fábrica como se sua vida tivesse terminado. Ainda assim, perante todas essas frustrações, a mulher-máquina não se permite demonstrar emoção. Enquanto ouve a notícia de seu desligamento, o rosto da personagem permanece inexpressivo. De maneira meticulosa, a ex-operária se encaminha até o vestiário, recolhe seus pertences e vai embora. Na cena seguinte, perdida em pensamentos, ela contempla o vazio, sentada em uma padaria. Novamente, o reflexo distorcido de sua imagem pode ser visto, na superfície do balcão. 


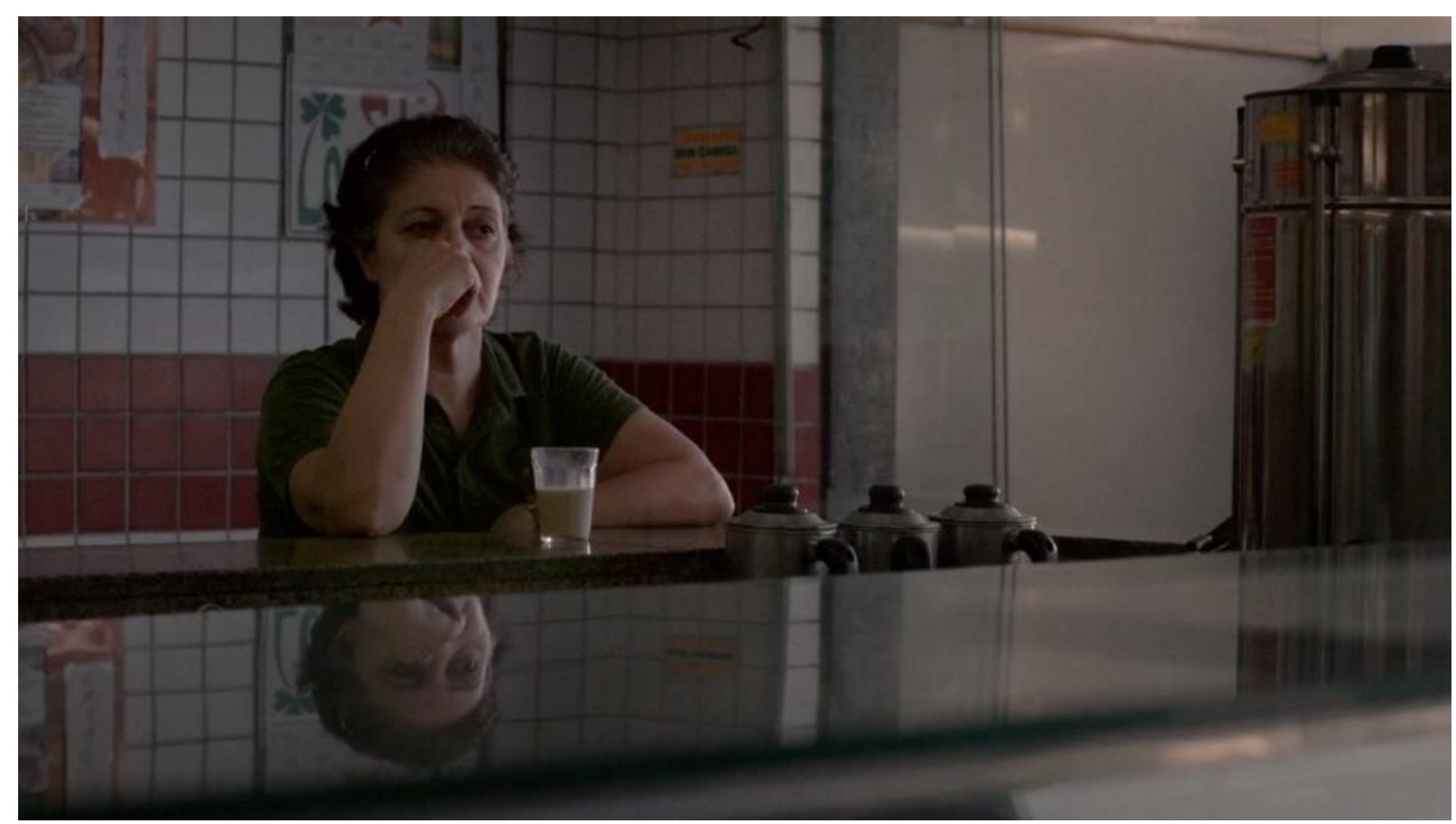

Imagem 44: Após sua demissão, Rosália toma café em uma padaria, pensativa. (C) Vitrine Filmes.

Sem poder visualizar um futuro possível, Rosália se abandona à melancolia. Mesmo durante a viagem compulsória à Argentina com o irmão, ela tem momentos de tristeza e desespero - sempre tomando o cuidado de guardar para si os sentimentos mais negativos. $\mathrm{O}$ choro no banheiro de um posto de gasolina é um raro momento de demonstração de fraqueza e vulnerabilidade, mas não há ninguém ali para ajudá-la e ela não consegue ajudar a si mesma. Rosália está encarcerada dentro de papéis sociais de que não é capaz de se libertar: sem trabalho ou uma condição financeira que lhe permita independência e sem a presença masculina que hipoteticamente daria sentido à sua vida, sem juventude e sem novos objetivos, está perdida em um mundo no qual não parece haver lugar para ela. 


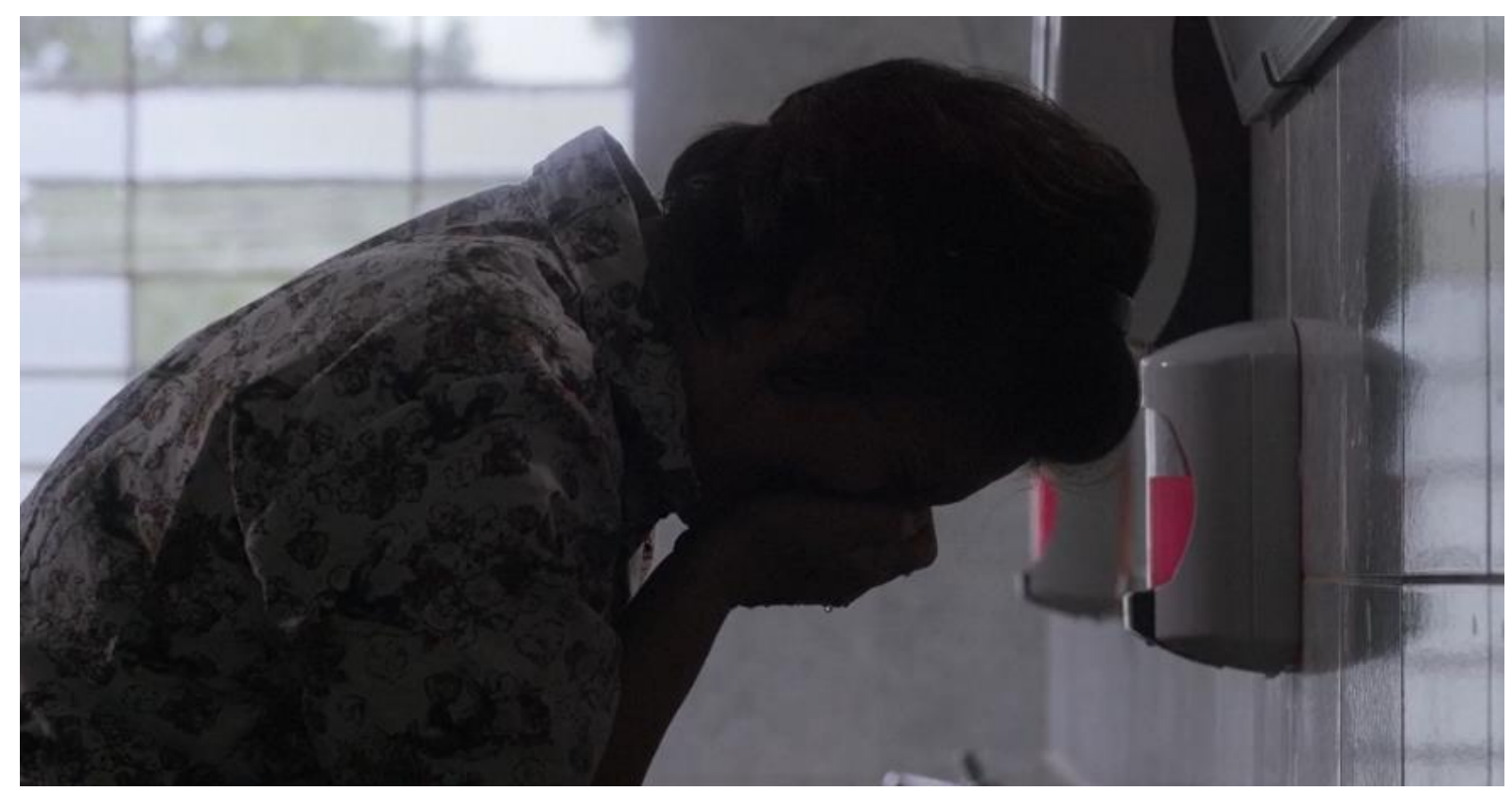

Imagem 45: Em uma parada, no início da viagem com o irmão, Rosália chora sozinha no banheiro. (C) Vitrine Filmes.

Ao longo da viagem - e de sua jornada diegética - acompanhamos a estagnação de Rosália dentro desse espaço neutro, de invisibilidade social. O presente que ela compra para si mesma, na estrada, é uma panela de pressão, o que diz muito sobre seu papel autodeterminado de cuidadora do homem em sua vida e de escrava das tarefas, sejam elas domésticas ou profissionais. O momento de virada, para a personagem, ainda que pouco significativo para mudar toda uma vida dedicada à submissão, talvez seja sua breve visita às Cataratas do Iguaçu. Diante da grandiosidade das quedas d'água, ensurdecida pelo barulho ao seu redor, ela contempla longamente a insignificância de sua própria existência. É somente depois dessa cena que Rosália esboça alguns sorrisos e seu semblante se torna um pouco mais leve, talvez aberto a uma mudança de pensamento. 


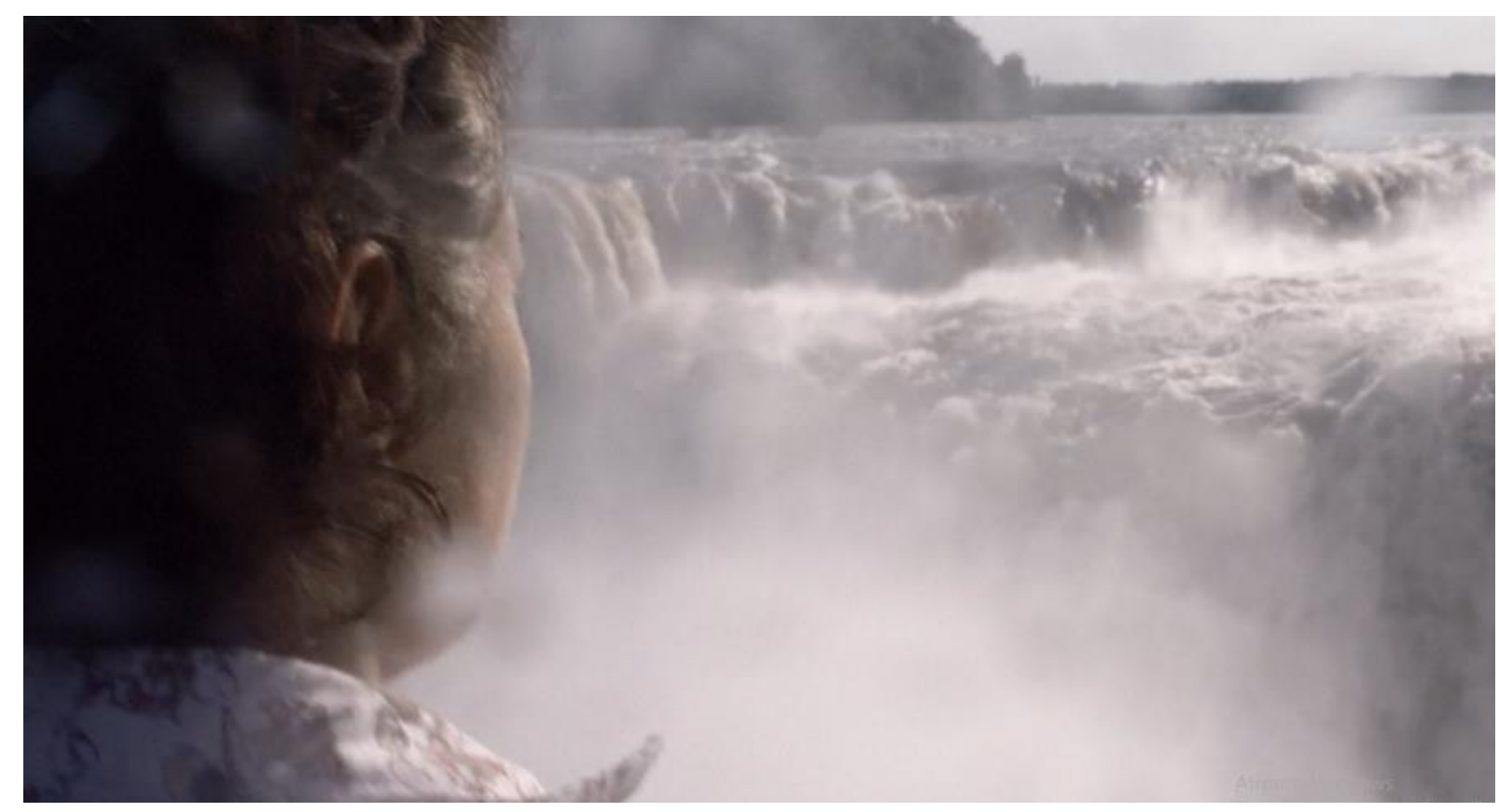

Imagem 46: Em um momento importante da narrativa, Rosália observa as Cataratas do Iguaçu. (C) Vitrine Filmes.

É um progresso muito pequeno, esse ligeiro momento de contemplação e reflexão, em um processo emancipatório que sequer chega a se iniciar, de fato. Quando Rosália e o irmão chegam à Argentina, ela continua executando tarefas, criando rotinas para preencher seus dias. Nem mesmo a conexão estabelecida com uma jovem mulher, mãe solo de um garotinho, no prédio onde fica hospedada, impulsiona qualquer mudança. Concretizando o altruísmo e o “instinto maternal” que se espera dela, Rosália deixa para a moça a panela que comprou durante o trajeto. Existe, nessa relação, um lampejo de sororidade, indicado nas breves conversas que estabelecem uma conexão entre as duas, mas isso não contribui para qualquer tipo de emancipação da personagem, que termina sua jornada praticamente da mesma maneira como a iniciou: dependente financeiramente e emocionalmente de uma figura masculina, sem muitas possibilidades de se libertar. $\mathrm{O}$ pequeno ato de rebeldia na cena final, quando vemos que ela roubou do hotel o quadro com a lembrança do momento mais significativo da viagem, acaba se tornando nulo diante da impossibilidade de alcançar qualquer transformação verdadeiramente positiva em sua vida. 


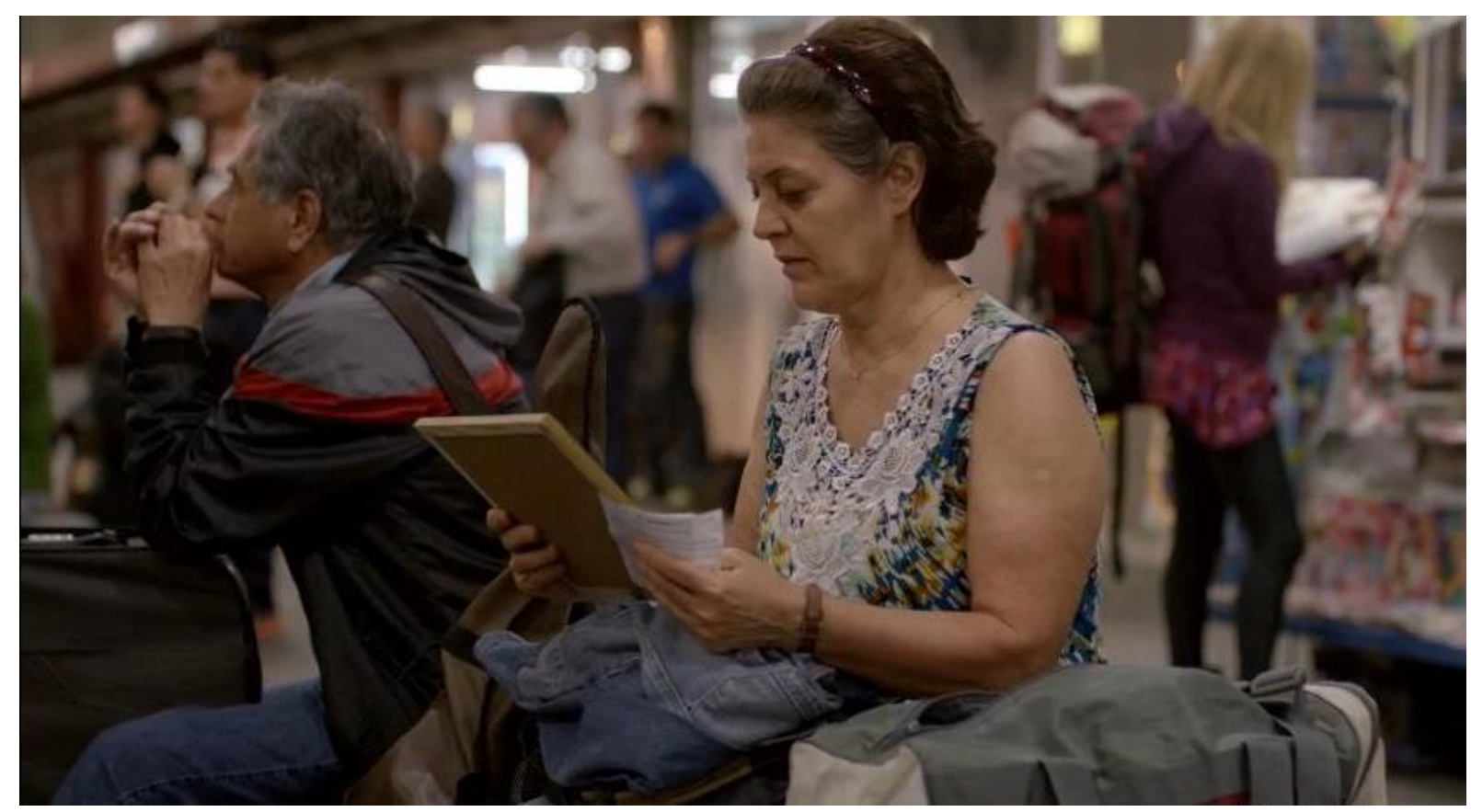

Imagem 47: Na rodoviária, esperando o ônibus de volta para casa, Rosália observa o quadro das cataratas que roubou do hotel. (C) Vitrine Filmes.

A emancipação, na jornada das heroínas, é um processo gradativo e contraditório, que envolve lutas, conquistas e privações. No início desta análise, nossa visão das três protagonistas era a de três mulheres que não possuíam protagonismo em suas próprias histórias, mas que eventualmente poderiam conquistá-lo no espaço diegético, terminando por se tornarem donas de suas próprias histórias, por meio de um desenvolvimento interno. De certo modo, essa visão de que todas as mulheres necessariamente precisariam ter trajetórias semelhantes havia sido moldada por expectativas sociais e culturais. Afinal, espera-se do sujeito feminino que seja mero objeto, permanecendo enquadrado dentro de moldes préestabelecidos, cumprindo determinados papéis e se mantendo dentro daquilo que é esperado por um sistema opressor. Contudo, a análise demonstrou que tanto é possível, como totalmente compreensível, que cada mulher se encontre em um diferente estágio da jornada emancipatória.

Quando vista como um processo gradual e conquistado a duras penas, a emancipação feminina se torna uma conquista ainda mais importante para a vivência de um protagonismo 
real e permanente. Nenhuma transformação verdadeira é possível sem o combate às estruturas que geram estagnação, alienação e desigualdade. Como arte transformadora e revolucionária, o cinema, especificamente os filmes contemporâneos brasileiros analisados, ajusta-se a essa gradação, refletindo com coerência a batalha constante das mulheres por protagonismo; em uma guerra que, embora desencadeada, ainda está longe de apresentar resultados satisfatórios. Nessa construção desafiadora do protagonismo, a linguagem fílmica dirige nosso olhar a realidades femininas diversas e processos muitas vezes incompletos. Dentre as três heroínas estudadas, a análise tornou evidente que Rosália não obteve a possibilidade de se emancipar em qualquer sentido, enquanto Hermila chegou a esboçar uma tentativa, ainda que vã, de se libertar da dominação masculina. Por outro lado, Val foi capaz de encontrar a felicidade na relação com a filha, esta sim absolutamente emancipada. Em uma realidade que ainda carrega tantas heranças do patriarcado, a sororidade talvez seja o caminho para que o processo emancipatório possa, de fato, acontecer. O mais importante, no entanto, é reconhecer a diversidade e perceber que, quando se trata do protagonismo feminino, cada mulher é única em seus conflitos, em seus erros e acertos. 


\section{Conclusão}

Vivemos em um mundo de contrastes, de oposições. O ser humano, no atual momento político e cultural de crescente polarização, tende a analisar fatos e situações de uma perspectiva dualista ${ }^{15}$ (masculino $\mathrm{x}$ feminino, direita $\mathrm{x}$ esquerda, matéria x espírito, evolução $\mathrm{x}$ retrocesso). Dentro desse contexto, iniciamos nossa jornada investigativa trazendo a questão de protagonismo versus não-protagonismo das personagens como um traçado linear, limitado a dois extremos: de um lado, a jornada se iniciaria com mulheres sem qualquer autonomia em suas próprias vidas; de outro, as três protagonistas escolhidas finalizariam suas histórias conquistando a emancipação.

Possivelmente, o maior aprendizado desta pesquisa foi ampliar o espectro de possibilidades no que concerne às jornadas femininas. $\mathrm{O}$ processo analítico se iniciou com a visão de que os filmes selecionados apresentariam protagonistas com desenvolvimentos semelhantes; sobretudo na parte final da trajetória, na qual supostamente todas ultrapassariam o limiar emancipatório. No entanto, um olhar mais profundo sobre essas obras acabou nos conduzindo por caminhos distintos.

O ser protagonista implica em permanência, em se reconhecer e ser reconhecida como uma mulher indubitavelmente emancipada, dona de seu próprio destino e única responsável pelas decisões e ações da própria vida. Essa é mulher que completou todos os requisitos na busca pela plenitude e alcançou a "linha de chegada" em sua trajetória humana. Entretanto, na realidade ainda tão desigual e repleta de complexidades na qual vivemos, tal conquista é praticamente impossível. Parece-nos muito mais verossímil pensar em estar protagonista.

\footnotetext{
15 Dualismo é uma concepção filosófica, fundamentada pelo pensador grego René Descartes, baseada na presença de dois princípios ou duas substâncias, duas realidades opostas, irredutíveis entre si e incapazes de uma síntese final ou de recíproca subordinação.
} 
Afinal, mesmo as mulheres que são capazes de se emancipar podem facilmente encontrar obstáculos externos que as forcem a retroceder em suas jornadas.

Essa ideia de triunfo, de que a trajetória necessariamente deve ter um fim, pode ser facilmente verificada na jornada do herói de Joseph Campbell. O retorno com o elixir da imortalidade, do ser imperecível, é o momento do reconhecimento efetivo do herói. Ele volta ao seu ponto de origem tendo obtido sucesso e mudança. "O herói é o patrono das coisas que se estão tornando, e não das coisas que se tornaram, pois ele é” (CAMPBELL, 1949, p. 149). A benção que o personagem heroico traz consigo restaura seu mundo comum.

O contra-argumento para esse "final feliz" proposto por Campbell poderia ser de que o aspecto mais importante é sempre a jornada, não o resultado, trazendo a ideia de que o processo em si seria suficiente para a obtenção da satisfação e da realização pessoais buscadas pelas mulheres - o que tampouco é verdadeiro. O senso comum que utilizamos para descrever a felicidade, na sociedade ocidental contemporânea, é uma definição simplista e não leva em consideração as individualidades e complexidades de cada ser humano - principalmente quando se trata da existência feminina.

A emancipação da mulher, ou seja, sua transformação em heroína, exige um processo mais sutil e abrangente do que aquele descrito pela "jornada do herói”, uma vez que cada ser feminino enfrenta desafios particulares ao seu lugar no mundo. Do mesmo modo, na presente pesquisa, cada personagem analisada é única em sua “jornada da heroína”. Não se trata apenas de problemáticas distintas, devido aos diferentes tipos sociais representados, mas de evoluções internas muito diversas. Assim como é desigual o comportamento das personagens e suas reações aos acontecimentos, no decorrer da trama, sua emancipação (ou estagnação) se processa em diferentes níveis. 
O primeiro passo para compreender esses níveis foi o aprofundamento na compreensão do que significa o termo empoderamento. Concluímos, por meio desta análise, que não há possibilidade de obtenção de poder sem que haja, primeiro, emancipação. Ademais, o caminho para que uma pessoa tenha a capacidade de se emancipar apresenta gradações e obstáculos duplamente desafiadores quando se trata do sujeito feminino. Não pode existir jornada emancipatória se a mulher não obtém, concomitantemente, sua independência financeira e sua libertação da dependência masculina.

Desse modo, a emancipação feminina é, sobretudo, um desenvolvimento ideológico, no qual a mulher toma consciência não apenas de sua condição, como de suas ideias, arriscando-se a mudar de posição na escala de valores. Neste estudo, observamos que Rosália (Pela Janela) e Hermila ( $O$ Céu de Suely) estão muito distantes de vivenciar tais transformações, de fato. Entre as protagonistas analisadas, Val (Que Horas Ela Volta?) parece a única a se encaminhar nessa direção, especialmente quando toma a decisão de se demitir e também toma para si o presente que havia comprado para Bárbara, mas que foi desprezado pela patroa. Trata-se de uma percepção de valores não somente materiais e econômicos, mas morais e éticos; um entendimento de que a patroa não se mostrava como uma pessoa de conduta humanista e, portanto, não seria digna de que Val abrisse mão dos próprios interesses em favor dela. Sua emancipação nasce essencialmente da escolha por cuidar de si mesma e da filha, antes de pensar em qualquer outra pessoa, o que culminaria na ação de abrir seu negócio como massagista - uma profissão pertinente para uma mulher que ambiciona por controle, já que a pressão estética é uma das maneiras pelas quais a sociedade costuma controlar as mulheres. Contudo, o que torna a personagem verdadeiramente emancipada é sua opção pelo papel materno, auxiliando a filha a tomar conta do neto, para que a jovem possa ter a chance de construir uma carreira profissional que lhe conceda mais protagonismo. 
Ainda que Hermila e Rosália ainda não se encontrem próximas a essa emancipação ideológica, suas jornadas não são menos reveladoras. Hermila é o reflexo da moça impetuosa, ansiosa por soluções rápidas, que se imagina como ser independente e dona do próprio corpo, porém se depara com adversidades que a obrigam a se submeter. Se algum dia ela conseguirá se emancipar em qualquer aspecto, dadas suas condições sociais, permanece um mistério, mas sua trajetória incompleta e de raros acertos é um espelho do que inúmeras jovens vivenciam diariamente em nosso país. Rosália, por sua vez, representa a mulher cansada e que já perdeu de vista qualquer possibilidade de emancipação, porque se deixou moldar por uma vida dura, de negações e autoimposições. Ela já não é capaz de alimentar as ideias que sustentariam ações para mudar as regras do jogo; simplesmente considera que não teve sorte na vida, abrindo mão de qualquer possibilidade de autonomia e aceitando a perda, sem sequer ter jogado suas cartas.

O êxito ou o fracasso das protagonistas em obter sua emancipação são menos relevantes, nesse contexto, porque não há início ou fim. O que dá sentido à jornada é justamente o fato de que ela é contínua. Não se trata de uma linha reta, mas de um caminho aberto e sinuoso, no qual os altos e baixos são naturais, até mesmo bem vindos, porque promovem aprendizado e evolução. São os constantes desafios que tornam as histórias das mulheres contemporâneas, no cinema ou fora dele, tão interessantes e significativas. Por isso, celebrar aquelas que são capazes de romper os obstáculos e obter protagonismo é tão importante e necessário; por esse mesmo motivo, uma mulher emancipada vale por muitas que ainda seguem lutando. O mundo precisa, desesperadamente, de suas heroínas. 


\section{REFERÊNCIAS BIBLIOGRÁFICAS}

ANCINE (Agência Nacional do Cinema). Observatório Brasileiro do Cinema e do Audiovisual. Disponível em: <https://oca.ancine.gov.br/cinema> Acesso em: 14 dez. 2019. ARAÚJO, Marcela Grecco de. Representações do feminino no cinema brasileiro de ficção: Mar de Rosas, Um Céu de Estrelas e Trabalhar Cansa. Campinas: [s.n.], 2015. Dissertação (Mestrado) - Universidade Estadual de Campinas, Instituto de Artes.

BAQUERO, Rute. Empoderamento: questões conceituais e metodológicas. Redes, Santa Cruz do Sul, v. 11, n. 2, p. 77-93, maio-ago. 2006.

BARBOSA, Nayton; BUCK, Beatriz; MAZETTO, Cecília; NARDIN, Ana Luísa; SILVA, Fabiano Souza. Caracterização e análise de "O Céu de Suely" de Karim Aïnouz, como uma narrativa de viagem. Disponível em: < http://www.rua.ufscar.br/caracterizacao-eanalise-de-o-ceu-de-suely-de-karim-ainouz-como-uma-narrativa-de-viagem/> Acesso em: 05 jun. 2018.

BARBOSA, Sérgio (orgs.) Comunicação latino-americana: O protagonismo feminino. São Paulo: Universidade Metodista de São Paulo / Unesco, 2003.

BARRETO, Raquel de Oliveira and PAULA, Ana Paula Paes de. "Rio da Vida Coletivo": empoderamento, emancipação e práxis. Rev. Adm. Pública [online]

BEAUVOIR, Simone. O Segundo Sexo. Rio de Janeiro: Editora Nova Fronteira, 1949.

BERNARDET, Jean-Claude. Cinema brasileiro: propostas para uma história. Rio de Janeiro: Ed. Paz e Terra, 1979.

BERTH, Joice. O que é empoderamento?. Belo Horizonte (MG): Letramento, 2018.

BIRMAN, Joel. Gramáticas do erotismo; a feminilidade e as suas formas de subjetivação em psicanálise. Rio de Janeiro: Civilização Brasileira, 2001.

BRAGANÇA, Felipe. Carta de Iguatu. Disponível em: <http://www.contracampo.com.br/ 77/iguatu.htm>. Acesso em: 02 abr. 2018.

BRONZITE, Dan. The Hero's Journey - Mythic Structure of Joseph Campbell's Monomyth. Disponível em: <http://www.movieoutline.com/articles/the-hero-journey-mythicstructure-of-joseph-campbell-monomyth.html>. Acesso em: 10 jul. 2017.

BRONZO, Carla B. Políticas locais de inclusão social, autonomia e empoderamento: reflexões exploratórias. In: Encontro da Associação Nacional de Pós-graduação em Administração. Salvador: Anpad, 2006. 
CAMPBELL, Joseph. O Herói de Mil Faces (1949). 10. ed. São Paulo: Cultrix/Pensamento, 1997.

DE LAURETIS, Tereza. A tecnologia do gênero. In: HOLLANDA, Heloisa Buarque de (org.). Tendências e impasses: o feminismo como crítica da cultura. Rio de Janeiro: Rocco, p. 206-242, 1994.

Alice Doesn't: feminism, semiotics, cinema: an introduction. London: The Mainillan Press, 1978.

DIDEROT, Denis. Paradoxo sobre o comediante, in A Filosofia de Diderot. São Paulo: Cultrix, 1964.

DUARTE, Rosália. Cinema \& Educação. Belo Horizonte, editora Autêntica, 2009.

DURAS, Marguerite. Os olhos verdes. Rio de Janeiro: Globo, 1988.

ENGELS, Friedrich. A origem da família, da propriedade privada e do Estado. São Paulo: Boitempo, 2019.

ERENS, Patricia (Ed.). Issues in Feminist Film Criticism. Indiana University Press, 1991.

FOUCAULT, M. O sujeito e o poder. In: DREYFUS, H., RABINOW, P. Michel Foucault: uma trajetória filosófica: para além do estruturalismo e da hermenêutica. Rio de Janeiro: Forense Universitária, 1995. p. 231-49.

Não ao sexo rei. In: MACHADO, R. (Org.). Microfísica do Poder. Rio de Janeiro: Edições Graal Ltda., 2004.

FREIRE, Paulo. Conscientização. São Paulo: Cortez e Moraes, 1979.

Ação cultural para a libertação e outros escritos. Rio de Janeiro: Paz e Terra, 1987.

Pedagogia do oprimido. Rio de Janeiro: Paz e Terra, 1981.

FREIRE, Paulo; SHOR, Ira. Medo e ousadia: o cotidiano do professor. $5^{\text {a }}$ edição. Rio de Janeiro: Paz e Terra, 1986.

FRIEDAN, Betty. Mística feminina. Petrópolis/RJ: Vozes, 1971.

GADOTTI, Moacir. Concepção Dialética da Educação. 8 ed. São Paulo: Cortez: Autores Associados, 1992.

A Educação contra a Educação. 4 ed. Rio de Janeiro: Paz e Terra, 1981.

GIDDENS, Anthony. As consequências da modernidade. São Paulo: Ed. UNESP, 1991.

GOHN, Maria da Glória. Empoderamento e participação da comunidade em políticas sociais. Saúde soc. [online], vol.13, n.2, p. 20-31. 2004.

GOMES, Paulo Emílio Salles. Cinema: Trajetória no subdesenvolvimento. 2. ed. Rio de 
Janeiro: Paz e Terra, 1986.

GUBERNIKOFF, Giselle. A imagem: representação da mulher no cinema. São Paulo: Summus, 2009. Revista Conexão, Comunicação e Cultura, Universidade de Caxias do Sul. HARRIGTON, Kimberly. When Will It Be Time's Up for Motherhood and Marriage? Disponível em: < https://medium.com/s/story/when-will-it-be-times-up-for-motherhood -andmarriage-2766d311bfae> Acesso em: 10 mai. 2018.

HASKELL, Molly. From Reverence to Rape: The Treatment of Women in the Movies. Estados Unidos: Penguin Books Ltd., 1977.

HERRIGER, Norbet. Empowerment in social work. Stuttgart: Eine Einfuhrung, 1997.

HOLANDA, Karla; TEDESCO, Marina Cavalcanti (orgs.). Feminismo e Plural: Mulheres no Cinema Brasileiro. Campinas: Papirus, 2017.

HOLLINGER, Karen. Feminist Film Studies. Estados Unidos: Routledge, 2012.

HOOKS, Bell. The oppositional gaze: Black female spectators. In Marc Furstenau (ed.), The Film Theory Reader: Debates and Arguments. Routledge, 2010.

HUDSON, Kim. The Virgin's Promise: Writing Stories of Feminine Creative, Spiritual and Sexual Awakening. Studio City: Michael Wiese Productions, 2010.

IORIO, Cecília. Algumas considerações sobre estratégias de empoderamento e de direitos. Texto elaborado para a ActionAid, 2002.

JOHNSTON, Claire. Women's Cinema as Counter-Cinema. In: (ed.). Notes on Women's Cinema. London: Society for Education in Film and Television, 1973.

KANT, Immanuel. Fundamentação da Metafísica dos Costumes. Lisboa: Companhia Editora Nacional. EDIÇÕES 70, 2007.

KAPLAN, Ann. A Mulher e o Cinema: Os Dois Lados da Câmera. Rio de Janeiro: Rocco, 1995.

KLEBA, M. E.; WENDAUSEN, A. Empoderamento: processo de fortalecimento dos sujeitos nos espaços de participação social e democratização política. 2009.

KUHN, Annette. Women's Pictures: Feminism and Cinema. Londres: Routledge \& Kegan Paul, 1982.

LEAL, Tatiane. A invenção da sororidade: Sentimentos morais, feminismo e mídia. Rio de Janeiro, 2019.

LIMA, Helcira (Org.). Representações do feminino no cinema brasileiro. Belo Horizonte: Viva Voz, 2013. 
LUKE, Helen. Woman Earth and Spirit: The Feminine Symbol and Myth. St. Louis: The Crossroad Publishing Company, 1984.

MACKAY, Kathy. How Fathers Influence Daughters. Los Angeles Times, 1983.

MARSH, Leslie L. Brazilian Women's Filmmaking: From Dictatorship to Democracy. University of Illinois Press, 2013.

MARTIN, Angela. Notes on feminism and film. Londres: British Film Institute, 1976.

MARX, Karl. “On the Jewish Question” (1843). In: The Marx-Engels Reader. Edited by Robert Tucker, New York: Norton \& Company, 1978. p. 26 - 46.

Selected writings. [Karl Marx; ed. David McLellan]. Oxford: Oxford University Press, 1977.

MENDES, Lia. Cinema e representação - Teoria Feminista do Cinema. 2016. Disponível em: <https://www.geledes.org.br/cinema-e-representacao-teoria-feminista-do-cinema/> . Acesso em: 10 mai. 2018.

MUlVEY, Laura. Visual Pleasure and Narrative Cinema. Film Theory and Criticism: Introductory Readings. Eds. Leo Braudy and Marshall Cohen. Nova York: 1989.

MURDOCK, Maureen. The Heroine's Journey: Woman's Quest for Wholeness. Boulder, Colorado: Shambhala Publications. 1990.

Articles: The Heroine's Journey. Disponível em: <http:// www.maureenmurdock.com/articles/articles-the-heroines-journey/> Acesso em: 10 mai. 2018.

NAGIB, Lucia. Além da diferença: a mulher no Cinema da Retomada. Devires, Belo Horizonte, v. 9, n. 1, p. 14-29, jan./jun. 2012.

PÉCORA, Luísa. Mulheres dirigiram 20,3\% dos filmes brasileiros lançados em 2016. Disponível em: <http://mulhernocinema.com/numeros/mulheres-dirigiram-203-dos-filmesbrasileiros-de-2016/>. Acesso em: 12 out. 2017.

PENLEY, Constance. The Future of an Illusion: Film, Feminism and Psychoanalysis. Minneapolis: University of Minnesota Press, 1990.

PEREIRA, Ana Catarina dos Santos. A mulher cineasta: da arte pela arte a uma estética da diferenciação. 2014. 357 f. Tese (Doutorado em Ciências da Comunicação). Universidade da Beira Interior. Covilhã (Portugal), 2014.

RAPPAPORT, Julian. Empowerment meets narrative: listening to stories and creating settings. American Journal of Community Psychology, v. 23, n. 5, p. 795-807, 2005. 
REIS, Thais Botrel. A mulher e o cinema: representação feminina no mercado cinematográfico brasileiro. Belo Horizonte: 2017. Dissertação (Mestrado) - Universidade Federal de Minas Gerais, Escola de Belas Artes.

ROCHA, Décio. DEUSDARÁ, Bruno. Análise de Conteúdo e Análise do Discurso: aproximações e afastamentos na (re)construção de uma trajetória. Disponível em: <http://www.scielo.br/scielo.php?script=sci_arttext\&pid=S1517-106X2005000200010> Acesso em: 15 jun. 2018.

ROMANO, J. O. Empoderamento: enfrentemos primeiro a questão do poder para combater juntos a pobreza [documento de apoio]. In: International Workshop Empowerment and Rights Based Approach in Fighting Poverty Together, 2002, Rio de Janeiro.

ROMANO, Jorge O.; ANTUNES, Marta (Org.). Empoderamento e direitos no combate à pobreza. Rio de Janeiro: Actionaid Brasil, 2002. p. 1-7.

SCOTT, Joan. História das mulheres. In: BURKE, Peter. A escrita da história: novas perspectivas. São Paulo: Editora da Universidade Estadual Paulista, p. 63- 95, 1992.

SCHULTZ, Theodore. Economic Value of Education. Columbia University Press, New York, 1963.

SCHUMANN, Karina; ROSS, Michael. Why Women Apologize More Than Men: Gender Differences in Thresholds for Perceiving Offensive Behavior. Disponível em: https://journals.sagepub.com/doi/abs/10.1177/0956797610384150> Acesso em 11 mar. 2019. SILVA, Luiz Etevaldo. O Sentido e Significado Sociológico de Emancipação. Revista eCurriculum, São Paulo, n.11 v.03 set./dez. 2013.

SILVERSTEIN, Melissa. Hollywood's Glass Ceiling: Why Doesn't the Film Industry Trust Women? Disponível em: <https://edition.cnn.com/2013/07/01/business/hollywoodsglass-ceiling-women/index.html> Acesso em: 17 mai. 2017.

SIMÕES, Mariana. "Tudo o que eu faço é contra o jornalismo". Disponível em: <https://apublica.org/2014/02/tudo-eu-faco-e-contra-jornalismo/>. Acesso em: 07 dez. 2018.

SOBCHACK, Vivian. Carnal Thoughts: Embodiment and Moving Image Culture. Berkeley: University of California Press, 2004.

SOUTO, Mariana. Invasores: classe, território e perspectiva no cinema brasileiro contemporâneo. Logos 49, v. 25, n. 01., UERJ. Rio de Janeiro, 2018.

SOUZA, Carlos Roberto de. A fascinante aventura do cinema brasileiro. São Paulo: Fundação Cinemateca Brasileira, 1981. 
STAPLES, Lee H. Powerful ideas about empowerment. Administration in Social Work, 14, p. 29-42. 1990.

TONET, Ivo. Educação, cidadania e emancipação humana. Ijuí: Unijuí, 2005.

TROTTIER, David. The Screenwriter's Bible. Los Angeles: Silman James, 1998.

TYLOR, Edward Burnett. Primitive Culture. Londres: John Murray, 1871.

USC Annenberg Communication and Marketing Staff. New USC Annenberg and TIME'S

UP study finds women of color festival programmers result in better representation of diverse filmmakers. Disponível em: <https://annenberg.usc.edu/news/research-andimpact/new-usc-annenberg-and-times-study-finds-women-color-festival-programmers>.

Acesso em: 30 jan. 2019.

VASCONCELLOS, E. M. O poder que brota da dor e da opressão: empowerment, sua história, teoria e estratégias. São Paulo: Paulus, 2003.

VOGLER, Christopher. The Writers Journey: Mythic Structure for Writers. Los Angeles: Michael Wiese Productions, 2007.

WHITE, Patricia. Women's cinema, world cinema: projecting contemporary feminisms. Estados Unidos: Duke University Press, 1964.

XAVIER, Ismail. O discurso cinematográfico: a opacidade e a transparência. $3^{\mathrm{a}}$ ed. rev. amp. São Paulo: Paz e Terra, 2005.

XAVIER, Ismail. Indagações em torno de Eduardo Coutinho e seu diálogo com a tradição moderna. In: Mostra diretores brasileiros: Eduardo Coutinho, cinema do encontro. Catálogo do CCBB/SP, 2004.

ZITKOSKI. Jaime José. Humanização/desumanização. In. STRECK, Danilo R; REDIN, Euclides; ZITKOSKI, Jaime José (org.). Dicionário Paulo Freire. Belo Horizonte: Autêntica, 2008. 


\section{REFERÊNCIAS FILMOGRÁFICAS}

Jeanne Dielman, 23, quai du commerce, 1080 Bruxelles. Direção de Chantal Akerman. Bruxelas: Paradise Films, Unité Trois, 1975. (202 min.).

Jogo de Cena. Direção de Eduardo Coutinho. Rio de Janeiro: VideoFilmes, Matizar, 2007. (105 min.).

O Céu de Suely. Direção de Karim Aïnouz. Rio de Janeiro: VideoFilmes, Celluloid Dreams, Shotgun Pictures, 2006. (90 min.).

Pela Janela. Direção de Caroline Leone. São Paulo: Vitrine Filmes, 2017. (87 min.).

Que Horas Ela Volta?. Direção de Anna Muylaert. Rio de Janeiro: Globo Filmes, 2015. (112 min.). 